UNTTED STATES

DEPARTMENT OF THE INTERIOR

GBOLOGICAL SURVEY

PROCEEDINGS OF CONFERENCE XXXVIII

A WORKSHOP ON "BARTHQUAKB HAZARDS ALONG

THE WASATCH FRONT, UTAH"

May 14-16, 1986

Salt Lake City, Utah

Sponsored by:

Utah Geological and Mineral Survey

Utah Division of Comprehensive Bmergeney Management

Federal Bmergency Management Agency

U.S. Geological Survey

EDITORS

Walter W. Hays and Paula L. Gori

U.S. Geological Survey

Reston, Virginia 22092

Open-File Report 87- 154

Compiled by Carla Kitzmiller

This report is preliminary and has not been edited or reviewed for conformity with U.S. Geological Survey publication standards and stratigraphic nomenclature. The views and conclusions contained in this document are those of the authors and should not be interpreted as necessarily representing the official policies, either expressed or implied, of the United States Government. Any use of trade names and trademarks in this publication is for descriptive purposes only and does not constitute endorsement by the U.S. Geological Survey. 
No rman $\mathrm{H}$. Bange rter

Governor of the State of Utah

Salt Lake City, Utah

Welcome to Ut ah and I'm delighted you're here. People come to Utah for all sorts of reasons--for our spectacular scenery, our cultural events, our skiing, etc., and I'm glad some people find our geologic hazards something to come to Ut ah to see rather than to run away from. I know Genevievel thinks that the State license plates could have "Utah, Geologic Hazards State" on them, but the Tourists Bureau does not share her enthusiasm.

E's and Earthquakes

The cornerstones of my administration are called the $3 \mathrm{E}$ 's--economic development, efficiency in government, and education. Earthquakes start with an "E" also. How does a State that wants to encourage development, cut costs of government, and increase our committment to schools reconcile these goals with earthquakes which would appear to discourage development and increase costs of government? Quite easily. We should tell it like it is. Developers are quite sophisticated. They know there is an earthquake hazard in Utah. The type of information you acquire reduces the scare factor by reducing their uncertainty and allows them to take appropriate actions.

As for efficiency in government, I'm committed to doing the right thing, not "cheap1y." We don't save the State any money when we build unsafe buildings, eventually the public has to pay--usually much more than it would have cost if it had been done right the first time.

\section{Great Salt Lake}

As Governor, I've learned quite a bit about geologic hazards, particularly the Great Salt Lake. First of al1, these hazards are bigger than we are. If we'd known the lake would keep rising and had we started earlier on this pumping plan, we'd have saved millions of dollars and hundreds of jobs. I don't want to say that about an earthquake after it has happen in this state. Developing public policy for earthquake preparedness is difficult. But to develop public policy we must understand the problem and that is why the work you are doing is so important to us. An earthquake is not like the lake rising over a period of 4 years and reminding us each day that it is a hazard in our backyards. I know that the cost of the lake's rampage is small compared to what will happen in a major earthquake on the Wasatch Front.

1 Eds. Note: Genevieve Atwood, Director and State Geologist, Utah Geological and Mineral Survey, Salt Lake City, Utah 
The lake also teaches a lesson about "normal" behavior. The lake is acting normally--it rises and $f a l l s$ in response to precipitation and evaporation. Its current rise is not unusual from a geologic perspective although it is very disconcerting to us. Earthquakes are "normal" too. Somehow we have learned to live compatibly with these hazards rather than deny their existence.

Development and Preparedness

I have always believed in personal preparedness. As a legislator and Governor, I believe in planning at a local government level. I believe in development, and I believe that buyers should beware and take considerable responsibility. But $I$ also believe in disclosure. A concerned buyer or homeowner or business owner should be able to obtain information about hazards on their property.

Action

I support and applaud your efforts. I like team efforts and I can see by the agenda that this is a team effort. I appreciate the U.S. Geological Survey for investing so much in our State. I am delighted to see the University of Jtah, the Utah State University, various local geologists, Utah Division of Comprehensive Emergency Management, the Federal Emergency Management Agency, and the Utah Geological and Mineral Survey all on the program. And, I don't want to see it stop here. The State of Utah needs to continue to be a part of this team and, specifically, to see that the scientific concepts get to the use r--the public. That's who goverment is for--the taxpayer. I want Utah Geological and Mineral Survey to make sure that the science doesn't just stay with the scientists. Genevieve, I want you and those other good people to know how much I care that the taxpayers get what they've paid for. And I want al1 of you to know how much I admire your dedication and work to help us understand the earthquake hazard in Utah. I sure hope you're successful and I sure hope the earthquake you have prepared us for doesn't happen while I'm Governor. 


\section{FOREWORD}

Welcoming Remarks at the Workshop on "Earthquake Hazards Along the Wasatch Front," Ut ah

The Honorable Gove rnor Norman H. Bangerter...................

\section{PREF ACE}

Dedication to Utahans Who are Making the Cooperative Research and Implementation Program in Utah Work.........................

\section{BACKGROUND INFORMATION AND SUMMARY OF THE WORKSHOP}

Background and Summary of the Workshop on "Earthquake Hazards Along the Wasatch Front, Utah"

Wa1ter Hays and Paula Gori

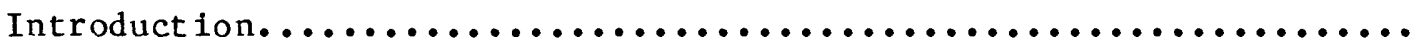
1984 Workshop on "Evaluation of Regional and Urban Earthquake

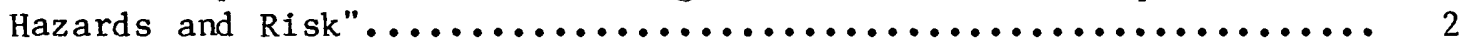

1985 Workshops on "Earthquake and Landslide Hazards"............ 3

The Research-Applications Process.......................... 3

Research and Implementation Triads in Utah.................. 6

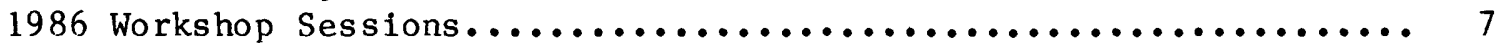

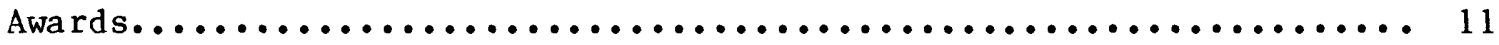

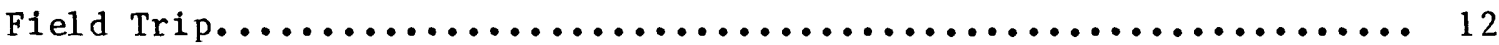

Reports of the Research and Implementation Triads.............. 12

Sugar House Quadrangle Atlas............................. 12

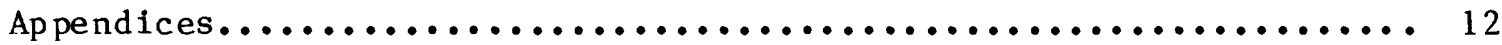

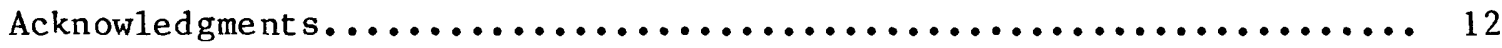

References......................................... 13

Appendix 1: Phase I: Regional Earthquake Hazards Assessements, Wasatch Front, Utah, Draft Work Plan: FY $84-86 \ldots \ldots \ldots \ldots \ldots \ldots \ldots \ldots 14$

Appendix 2: Phase II: Regional Earthquake Hazards Assessments of Research and Implementation Along the Wasatch Front, Utah:

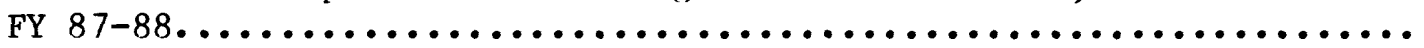

\section{EVALUATION}

Observations on the 1986 Workshop

Peter May.........................................

Statement Prepared for Presentation to the House Subcommittee on Science Research and Technology, March 10, 1987

Don Mabey.

\section{REPORTS OF THE RESEARCH AND IMPLEMENTATION TRIADS}

Tectonic Framework and Earthquake Potential of the Wasatch Front Area and Other Parts of Utah

Michael Machette, Bil1 Lund, and Walter Arabasz................ 
The Ground Shaking Hazard and Various Aspects of Loss Estimation in

the Wasatch Front Region of Utah

Delbert Ward, Albert Rogers, and Robert Smith............... 60

Ground Failure, Rock Falls, and Tectonic Deformation in the Wasatch

Front Area

Loren Anderson, T. Leslie Youd, and Earl Brabb............... 75

Collecting, Compiling, Translating, and Dis seminating Ea rthquake-Hazards

Information for Urban and Regional Planning and Development in the

Wasatch Front Area, Utah

Gary Christenson, Jarold Barnes, Joseph Moore, Craig Nelson,

Robert Robinson, Mike Lowe, and Willi am Kockelman............. 80

Development and Implementation of Improved Loss-Reduction Measures

In IJt ah

Genevieve Atwood, Lorayne Tempest, Gary Johnson and Jerome 01son....

Integrating Scientific and Engineering Information into Earthquake-

Resistant Design in Utah

Lawrence Reaveley, Delbert Ward, and Walter Hays............... 96

\section{SUGAR HOUSE QUADRANGLE ATLAS}

Applying Digital Cartographic and Geographic Information Systems Technology and Products to the National Earthquake Hazards Reduction Program

Robert Alexander, Michael Crane, Thomas DiNardo, Leanne Firestone,

Eldon Jessen, Carol Mladinich, and Car1 Rich.................100

\section{APPENDIX A}

Glossary of Terms used in Earthquake Hazards Assessments............ A-1

APPENDIX B

Location of Strong Motion Instruments in Utah................... B-1

APPENDIX C

List of Participants at the Workshop........................... 
DEDICATION TO THE UTAHANS WHO ARE MAKING THE COOPERATIVE RESEARCH AND IMPLEMENTATION PROGRAM IN UTAH WORK

When the concept of a cooperative Federal-State research and implementation program to reduce potential losses from future earthquakes in Utah was proposed in 1983, two things were clear:

1) The concept represented a worthy and challenging goal.

2) Accomplishment of the goal would have great value to Utah and to the Nation.

Now, some 4 years after the initiation of the cooperative 5-year program under the auspices of the U.S. Geological Survey's "Assessment of Regional Earthquake Hazards" program element, the concept has become reality. Good progress has been made in both the research and the implementation components of the program. Strong motion instruments have been deployed in strategic locations. A critical base of technical knowledge has been created as a result of the research. Working relations at the city, county, State, and Federal levels have been improved. Translation of research results into formats that can be used by nonspecialists is happening, and these results are being disseminated and communicated widely to the right people by three new county geologists and others. Applications in the form of enlightenment uses, decisionmaking uses, and practice uses, are increasing throughout Utah.

This report, the proceedings of the third consecutive annual USGS-FEMA workshop in Utah, is dedicated to all of the Utahans who have had a part in the cooperative research and implementation program in Utah. They represent all parts of Utah life: universities, the private sector, private citizens, professionals, representatives of state-city-county government agencies, and public officials.

On Friday, Ju1y 18, 1986, at the workshop, five Utahans were singled out for their singular accomplishments in fostering implementation activities to reduce lossses from future earthquakes in Utah. The recipients were:

1) The Honorable Robert Madsen, Mayor of Odgen,

2) Genevieve Atwood, Director and State Geologist of Utah Geological and Mineral Survey,

3) Lorayne Tempest, Director Utah Division of Comprehensive Emergency Management,

4) Delbert Ward, Principal of Structural Facilities, Inc., and formerly Executive Director of Utah Seismic Safety Advisory Council (19771980), and

5) Lawrence Reaveley, Vice President, Reaveley Engineers and Associates.

We are pleased to call attention to the accomplishments that are being made in Utah through the efforts of many dedicated people.

John R. Filson

U.S. Geological Survey
Richard W. Krimm

Federal Emergency Management Agency 
BACKGROUND AND SUMMARY OF THE WORKSHOP ON

"EARTHQUAKE HAZARDS ALONG THE WASATCH FRONT, UTAH"

By

Wa1ter W. Hays and Paula L. Gori

U.S. Geological Survey

Reston, Virginia 22092

\section{INTRODUCTION}

One hundred and thirty earth scientists, engineers, planners, and emergency management specialists participated in a 5-day wo rks hop on "Earthquake Hazards Along the Wasatch Front, Utah." This workshop, convened under the auspices of the National Earthquake Hazards Reduction Program (NEHRP), was held in Salt Lake City, Utah, on July 14-18, 1986. The sponsors of the workshop we re the Ut ah Geological and Mineral Survey (UGMS), Ut ah Division of Comprehensive Emergency Management (CEM), the Federal Emergency Management Agency (FEMA), and the U.S. Geological Survey (USGS). These four agencies were the nucleus of the State-Federal partnership formed in Utah in in 1983 to carry out the NEHRP activities. The universities were also an important part of the partnership and performed a large fraction of the research with funding from the National Science Foundation and USGS.

This workshop was the third workshop convened by UGMS, CEM, FEMA, and the USGS since October 1983 when the Wasatch front was established as the priority region for five years in the U.S. Geological Survey's national program, "Assessment of Regional Earthquake Hazards," an element of the NEHRP. Phase I of the program consisted of a three year emphasis on research and implementation (see Appendix 1 at the end of this section) and Phase II consisted of a two year emphasis on implementation (see Appendix 2 at the end of this section). The workshops fulfilled a commitment made in 1983 to bring earth scientists, engineers, architects, planners, and emergency management specialists of Utah together each year in a major forum with the goals of:

-- Providing current information on the earthquake hazards of ground shaking, surface fault rupture, earthquake-induced ground failure, and regional tectonic deformation along the Wasatch front which are subjects of a vigorous research program funded mainly by USGS and the National Science Foundation.

-- Evaluating current research results to determine the most appropriate research agendas for the future.

-- Providing publications and maps that are translated to meet the actual and perceived needs of various user groups in Utah.

-- Describing how the body of technical data and accumulated knowledge can be applied in the form of cost-effective 1 oss-reduction measures along the Wasatch front.

-- Fostering an environment at the state and local level that will lead to implementation of specific loss-reduction measures. These measures can be classified in three primary categories: a) enlightenment uses - new knowledge is used to raise awareness of certain phenomena or issues, b) decisionmaking uses - new knowledge is used to shape legislative 
initiatives, codes, regulation, and program planning and, c) practice uses

- new knowledge is used to change construction practices; land use; and response, preparedness, mitigation, and recovery actions and policies (see Yin and Moore, 1985).

The two prior workshops are summarized below:

1984 WORKSHOP ON "EVALUATION OF REGIONAL AND URBAN EARTHQUAKE HAZARDS AND RISK"

On August 14-15, 1984, the workshop "Evaluation of Regional and Urban Earthquake Hazards and Risk in Jtah" was held in Salt Lake City at the State Capito1. The proceedings was published as U.S. Geological Survey Open-File Report 84-763). One hundred and fifty individuals attended the meeting which resulted in:

-- An assessment of the present state of knowledge of earthquake hazards and risk in Utah with emphasis on the scientific, engineering, and societalpreparedness components.

-- The determination of what additional scientific, engineering, and societal-preparedness information is needed to achieve the goal of reducing potential losses from future earthquakes in Utah.

\section{WORKSHOPS ON "EARTHQUAKES AND LANDSLIDE HAZARDS"}

Two workshops on earthquake and landslide hazards and risk in Ut ah were convened in Salt Lake City in 1985, the first on July 10-11 and the second on July 30-August 1. The goal of both workshops was to continue the planning and partnership process begun in the 1984 workshop. The strategy was to increase the capability of State and local governments, private industry, academic institutions, and engineers and architects to take specific achievable actions to reduce losses from earthquakes and landslide hazards.

The first workshop was designed by UGMS and attended by 25 people. It had the following agenda:

1. Definition of the most essential elements of an earthquake hazards reduction program for UGMS.

2. Suggestions for interfacing effectively with the National Earthquake Hazards Reduction Program, University of Utah Seismographic Station, State and local government organizations, and others in the private sector.

3. Possible long-term monitoring of precursory phenomena for earthquakes along the Wasatch front.

4. The role of UGMS immediately after a large earthquake in Utah.

The following special roles and responsibilities were recommended by the participants for UGMS to consider:

1. Collection, management, and distribution of information and maps to become a permanent memory of earthquake and landslide hazards in Utah). 
2. Translation of information and maps on earthquake and landslide hazards for use by local governments. The goal is to trans form technical data into formats that can be used by nonspecialists to answer the questions "where," "when," and, "how bad."

3. Review, upon request, site and development plans for local and State government organizations.

4. Evaluation of hazards.

5. Selected monitoring of hazards.

6. Advocate of seismic safety.

7. Coordination of the scientific aspects of post-earthquake investigations, working closely with CEM, university scientists, USGS, and others such as Earthquake Engineering Research Institute.

8. Taking the lead in providing technical advice to State and local government organizations and in documenting surface and subsurface geologic effects and "perishable" data immediately after a damaging earthquake.

The second workshop was designed by CEM. It focused on ways to assist the staffs of CEM and cities and counties in the State to use hazards information and maps in implementing effective loss-reduction strategies. Sixty emergency managers, urban planners, and county geologists participated in this workshop which had the following agenda:

1. Review of methods, map formats, map scales, and potential applications of existing technology to depict the ground-shaking hazard in Ut ah in ways that meet the needs of Utah user groups.

2. Review of methods, map formats, map scales, and potential applications of existing technology to depict the hazards of surface faulting and tectonic deformation in ways that meet the needs of Utah user groups.

3. Review of methods, map scales, and potential applications of existing technology to depict the earthquake-induced ground-failure hazard ( 1 iquefaction and landslides) in ways that meet the needs of Utah user groups.

The participants concluded the workshop with a field trip to view the Thistle landslide, fault scarps along the Wasatch front, and ot her geologic

features. The field trip provided an opportunity for nonscientists to see the geologic features that Utah scientists are talking about.

\section{THE RESEARCH-APPLICATIONS PROCESS}

In Utah, and elsewhere in the Nation, the emphasis in on applications of knowledge to mitigate hazards. Figure 1 shows the overall researchapplications process of the NEHRP schematically in terms of four elements. 


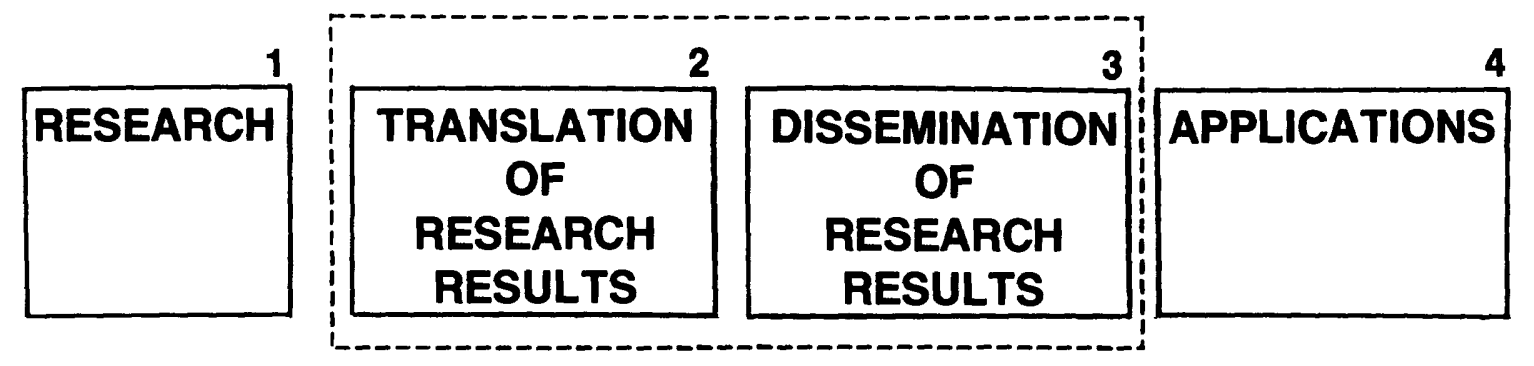

Figure 1.--Schematic illustration of the research-applications process that is being used to link producers and users of earthquake hazards information in Utah. The process is dynamic and requires many actions over a period of several years by many people having a variety of backgrounds, training, and experience. The key to success is a "partnership" like the one that is described in Appendices 1 and 2 at the end of this section where each partner has a "stake" in the overall process, beginning with the planning and continuing to the applications. Research produces the knowledge base that makes implementation on loss-reduction measures relevant for the Wasatch front area. However, applications of the research would lag behind knowledge without translation and dissemination activities to transform the research results into formats that define "where," "what," "when," and "how of ten" for those who will use the information. Applications are carried out by many different people having backgrounds encompassing science, architecture, city planning, engineering, economics, social science, emergency management, and politics. 
1. Research - Basic and applied studies that are designed to increase the knowledge base (according to the 1977 National Earthquake Hazards Reduction Act and its extensions) in the following areas:

-- Bas ic earthquake causes

-- Earthquake prediction

-- Artificial induction of earthquakes

-- Earthquake modification or control

-- Preparation of risk analyses and land use guidelines

-- Earthquake ef fects

-- Social and economic adjustments that would lessen the harm done by eart hquakes

-- Foreign and domestic experience with earthquakes

2. Translation - activities to "translate" technical results into products that can be used more readily by nonscientists and nonengineers. The goal of the translated results is to provide the best available explicit answers to the questions, where, what, when, and how of ten.

3. Dissemination - activities to place research results in the hands of informed users, other researchers, and program managers and to foster the communication process.

4. Applications - ways to utilize the knowledge base produced by the research program of the NEHRP (i.e., enlightenment uses, decisionmaking uses, and practice uses) (see Yin and Moore, 1985). In terms of the implementation plan of the 1977 National Earthquake Hazards Reduction Act, applications should include:

-- Preparations for earthquakes, including prediction, evaluation of hazards, earthquake scenarios, earthquake warnings, and response planning.

-- Development of ways for State and local government to use information about earthquake risk in land-use planning.

-- Development of standards and codes for earthquake-resistant construction.

-- Examination of how earthquake hazards can be reduced through Federal construction 1 oans and licenses.

-- Determination of the appropriate roles of insurance, loans, and relief in moderating the impact of earthquakes.

-- Dissemination of information about all aspects of earthquakes.

The range of applications that are being considered in Utah can be placed in the three categories of enlightenment, decisionmaking, and practice uses. The following listing is a representative example:

1. Enlightenment Uses

-- Public information and educational programs.

-- National, regional, and local hazards and risk assessments.

-- Response to damaging earthquakes (including domestic and worldwide analogs). 


\section{Decisionmaking Uses}

-- Seismic safety organizations.

-- Requi rements for design, inspection, and enforcement for new construction (buildings, schools, hos pitals, dams, nuclear power plants, and 1ifeline systems).

-- Regulations for land use (seismic safety elements, fault set-back ordinances, etc.).

-- Mitigation strategies (retrofit and strengthening of existing buildings, facilities, and lifeline systems, etc.).

\section{Practice Uses}

-- Regional earthquake preparedness planning in conjunction with an earthquake forecast, warning, or prediction.

-- Retrofit of buildings (i.e., base-isolation systems, repair and strengthening, etc.).

-- Application of the seismic provisions of a building code.

-- Retrofit of bridges.

-- Removal of hazardous buildings.

-- Business preparedness (i.e., a utility company).

\section{RESEARCH AND IMPLEMENTATION TRIADS IN UTAH}

The procedures used in the 1986 workshop were designed to strengthen the partnership and all as pects of the research-applications process in Utah. The key was the formation of six "research and implementation triads." Each triad consisted of two (or more) representatives from Ut ah and one representative from the Federal Government. The goals of each triad were to:

1. Perform a critical evaluation of the earthquake hazards research and implementation activities in the Wasatch front area during the past 3 years. (Phase I - see Appendix 1 at end of this section).

2. Recommend priorities for research projects and implementation activities for the next 2 years. (Phase II - see Appendix 2 at end of this section).

The triads were as follows:

Triad I: Triad for Tectonic Framework and Earthquake Potential of the Wasatch

Front Area and Other Parts of Ut ah

-- Mike Machette, USGS

-- Walter Arabasz, University of Utah

-- Bil1 Lund, UGMS

Triad II: Traid for the Ground Shaking Hazard and Loss Estimation in the Wasatch Front Area

-- Albert Rogers, USGS

-- Robert Smith, University of Utah

-- Delbert Ward, Structural Facilities Inc. 
Triad III: Triad for the Ground Failure Hazard and Tectonic Deformation in the Wasatch Front Area

-- Ear1 Brabb, USGS

-- Loren Anderson, Ut ah State University

-- Les Youd, Brigham Young Unive rsity

Triad IV: Triad for Implementation of Earthquake Hazards Information in the Regional and Urban Planning Process in the Wasatch Front Area

-- Willi am Kockelman, USGS

-- Jerold Barnes, Salt Lake City Planning Commission

-- Gary Christenson, USMS

-- Craig Nelson, Salt Lake City/County Geologist

-- Robert Robinson, Utah/Juab County Geologist

-- Mike Lowe, Weber/Davis County Geologist

-- Joseph Moore, West Valley City

Triad V: Triad for the Development and Implementation of Improved Loss-

Reduction Measures in Utah

-- Jerry 01son, FEMA

-- Gary Johnson, FEMA

-- Genevieve Atwood, UGMS

-- Lorayne Tempest, CEM

Triad VI: Triad for Integrating Scientific and Engineering Research on Earthquake and Mitigation Activities in Utah

-- Walter Hays, USGS

-- Delbert Ward, Structural Facilities, Inc.

-- Lawrence Reaveley, Reaveley Engineers and As sociates

-- Don Mabey, UGMS

1986 WORKSHOP SESSIONS

Following welcoming remarks by the Honorable Governor Norman H. Bangerter of Utah, the workshop process was developed in a series of plenary and discussion group sessions. The themes, objectives, and speakers for each plenary session are described below. Research was emphasized during the first three days and implementation during the last two days.

PLENARY SESSION I: TECTONIC FRAMEWORK AND EARTHQUAKE POTENTIAL OF THE WASATCH FRONT AREA AND OTHER PARTS OF UTAH.

Objective: To review the most significant research accomplishments and to recommend the most appropriate research agenda for the next 2 years.

\section{Spe akers:}

Significance of the 1983 Borah Peak, Idaho, earthquake

-- Robert Smith, University of Utah,

Observational seismology and earthquake hazards evaluation in the Wasatch front area

-- Walter Arabasz, University of Utah 
Quaternary geology along the Wasatch front - Evidence for additional segmentation and for large changes in slip rate on the Wasatch front zone --Michael Machette, U.S. Geological Survey

Neotectonic framework of the central Sevier Valley area, Utah, and its relationship to seismicity

-- Ernest Anderson, U.S. Geological Survey

Trenching along the Wasatch front

-- Willi am Lund, Ut ah Geological and Mineral Survey

-- David Schwartz, U.S. Geological Survey

Structure of the Salt Lake segment, Wasatch normal fault zone: Implications for rupture propagation during normal faulting.

-- Ronald Bruhn, Unive rsi ty of Utah

Paleoseismicity and earthquake hazards: Evaluation of the West valley fault zone, Salt Lake urban area

-- Jeffrey Keaton, Dames and Moore

-- Susan 01ig, Unive rsity of Utah

A statistical analysis of segmentation of the Wasatch fault

-- Russell Wheeler, U.S. Geological Survey

Neotectonics of the Hanse1 Valley-Pocatello Valley corridor, Northern Utah and Southern Idaho

-- James McCalpin, Utah State University

Interpretation of a $30 \mathrm{~km}$ Seismic-Reflection Profile Across the Wasatch Fault Zone Near Nephi, Utah

-- Mary Lou Zoback, U.S. Geological Survey

\section{DISCUSSION SESSION I: DEVELOPMENT OF A RESEARCH AGENDA FOR 1986-1988}

Objective: In the context of the preceding plenary session theme, three simultaneous discussion groups addressed the questions: 1) What should the research agenda be for the Wasatch front during the next 2 years? 2) What should the relative priorities be? and 3 ) Why?

PLENARY SESSION II: THE GROUND SHAKING HAZARD AND VARIOUS ASPECTS OF LOSS ESTIMATION IN THE WASATCH FRONT AREA

Objective: To review the research program by means of a series of short presentations stating: 1) the objectives of the research during the past 3 years, 2) the extent to which reliable answers have been obtained to fundamental questions, 3) the most significant accomplishments, and

4) specific recommendations for additional research in the next 2 years to advance the state of knowledge.

\section{Speakers :}

Characterization of the ground-shaking hazard and site amplification phenomena for earthquake-resistant design

-- Walter Hays, U.S. Geological Survey 
Integrating seismic hazard, vulnerability, and risk assessments: Theory and practice

-- Ted Algermissen, U.S. Geological Survey

Analysis of earthquake ground-shaking hazard for the Salt Lake City-OgdenProvo Region

-- Maurice Power, Geomatrix Consult ants

Subsurface geology along the Wasatch Front

-- Don Mabey, Utah Geological and Mineral Survey

Geographic variation in relative ground shaking in the Wasatch front urban corridor

-- John Tinsley, U.S. Geological Survey

-- Kenneth King, U.S. Geological Survey

Earthquake loss estimates for utility systems and State-owned buildings in Salt Lake and Davis Counties

-- Craig Taylor, National Technical Systems

DISCUSSION SESSION II: DEVELOPMENT OF A RESEARCH AGENDA FOR 1986-1988

Objective: In the context of the preceding plenary session theme, three simultaneous discussion groups addressed the questions: 1) What should the research agenda be for the Wasatch front during the next 2 years? 2) What should the relative priorities be? and 3) Why?

PLENARY SESSION III: GROUND FAILURE, ROCK FALLS, AND TECTONIC DEFORMATION IN THE WASATCH FRONT AREA

Objective: To review the research program by means of series of short presentations stating: 1) the objectives of the research during the past 3 years, 2) the extent to which reliable answers have been obtained to fundamental questions, 3) the most significant accomplishments, and 4) specific recommendations for research in the next 2 years to advance the state of knowledge.

Speakers:

Liquefaction potential in Davis, Salt Lake, and Ut ah Counties

-- Loren Anderson, Utah State University

Potential earthquake-induced tectonic subsidence along the Wasatch front, north-central Ut ah

-- Jeffrey Keaton, Dames and Moore

Liquefaction severity index

-- Les Youd, Brigham Young University

Wasatch front earthquake rockfall hazard

-- William Case, Utah Geological and Mineral Survey 
Objective: In the context of the preceding plenary session theme, three simultaneous discussion groups addressed the questions: 1) What should the research agenda be for the Wasatch front during the next 2 years? 2) What should the relative priorities be? and 3 ) Why?

PLENARY SESSION IV: RESPONSE TO INFORMATION NEEDS OF SPECIAL GROUPS IN UTAH

Objective: To review and translate the latest research results on the Wasatch front earthquake hazards and risk for planners, engineers, and architects.

Objective: The results of the Wasatch Front Earthquake Hazards Reduction Program are not only exciting to research scientists, they also have specific implications to planners, architects, and engineers. This session will provide those responsible for developing and implementing earthquake hazard reduction measures an understanding of the current knowledge of the Wasatch Front earthquake threat and an insight into what additional information should be expected from continuing research.

Panelists:

--Michael Machette, U.S. Geological Survey

--Walter Arabasz, University of Ut ah

--Willi am Lund, Ut ah Geological and Mineral Survey

--Al bert Rogers, U.S. Geological Survey

--Jeff Keaton, Dames and Moore

--Del bert Ward, Structural Facilities, Inc.

- Ear1 Brabb, U.S. Geologica1 Survey

--Loren Anderson, Ut ah State University

--Les Youd, Brigham Young University

PLENARY SESSION V: EARTHQUAKE-RESISTANT DESIGN IN UTAH FROM THE PERSPECTIVES OF ARCHITECTS AND ENGINEERS--WHAT DO WE KNOW NOW AND WHAT DO WE STILL NEED TO KNOW?

Objective: 1) To explore how the results of research can be translated so that they can be implemented by building professionals, 2) to identify what is still unknown about the earthquake hazards so that these professionals also understand the uncertainties, and 3) to obtain a sense of priorities from these groups of what information they need most in order to do their jobs better.

Panelists:

-- Jerold Barnes, Salt Lake City Planning Commission

-- Gary Christenson, Utah Geological and Mineral Survey

-- Robert Robinson, Utah/Juab County Geologist

-- Mike Lowe, Weber/Davis County Geologist

-- Craig Nelson, Salt Lake City/ County Geologist

-- James Tingey, Utah Division of Comprehensive Eme rgency Management

-- William Kockelman, U.S. Geological Survey 
PLENARY SESSION VI: INFORMATION ON EARTHQUAKE HAZARDS FOR REAL ESTATE REPRESENTAT IVES, DEVELOPERS, FINANCLAL INSTITUTIONS, AND NEWS MFDIA

Objective: To answer questions involving issues frequently raised by the public and those whose actions influence development and to make information on the Wasatch Front earthquake hazard available to a wide audience. Such information, if properly used, will encourage responsible development and reduce unnecessary exposure to earthquake hazards.

Invited Speaker

Dr. Amar Chaker, University of Science and Technology Houari Bounediene, Algiers, Algeria, gave a presentation on the magnitude $\mathrm{M}_{S} 7.3 \mathrm{E} 1$ Asnam earthquake that struck Algeria on October 10, 1980. With the exception of being a thrust fault tectonic environment, many aspects of the Algerian experience are highly relevant to the Wasatch front. The earthquake produced a $35 \mathrm{~km}-1$ ong surface rupture, destroyed about 85 percent of E1 Asnam (1ocated about $10 \mathrm{~km}$ from the epicenter), generated ground shaking estimated to be in the order of $0.5 \mathrm{~g}$ or greater, caused many deaths and $i$ njuries and severely impacted the economic resources of Algeria. Since the earthquake, Algeria has acquired and deployed 90 strong motion instruments, completed a comprehensive seismic microzonation study to guide code changes and land use and construction practices, and established an Institute of Earthquake Engineering and Applied Seismology. None of these accomplishments would have occurred that rapidly without the earthquake. Had the earthquake occurred on October 9, instead of October 10, a holiday, 40,000 school-age children would have probably been killed or injured.

Panelists:

-- Genevieve Atwood, Utah Geological and Mineral Survey

-- Lawrence Reaveley, Reaveley Engineers and As sociates

-- Lorayne Tempest, Utah Comprehensive Emergency Management

-- Gary Johnson, Federal Emergency Management Agency

-- Jerome Oakley, Federal Emergency Management Agency

-- Walter Hays, U.S. Geological Survey

-- Walter Arabasz, University of Utah

AWARDS

Five Utahans received awards for their accomplishments in fostering implementation activities to reduce losses from earthquake hazards in Utah. The recipients were:

1) Robert Madsen, Mayor of Ogden

2) Genevieve Atwood, Director of Utah Geological and Mineral Survey and State Geologist

3) Lorayne Tempest, Director of Utah Division of Comprehensive Emergency Man agement

4) Delbert Ward, Principal, Structural Facilities, Inc., Formerly Executive Director of Utah Seismic safety Advisory Council (1977-1980) 
5) Lawrence Reaveley, Vice President, Reaveley Engineers and Associates

The awards were presented by Dr. John R. Filson, Chief, Office of Earthquakes, Volcanoes, and Engineering, U.S. Geologica1 Survey (USGS) and Gary Johnson, Chief, Earthquake and Natural Hazards Programs Division, Federal Emergency Management Agency (FEMA). The citation for each recipient read:

"In grateful recognition of your demonstrated leadership and recognized accomplishments in fostering the implementation of measures to reduce 1 osses due to earthquakes in the State of Utah."

These awards are the first given for implementation activities under the auspices of the National Earthquake Hazards Reduction Program.

FIELD TRIP

Objective: To provide nonscientists and nonengineers with insight into the kinds of information being used to define the Wasatch Front earthquake threat and to devise mitigation measures. Participants took a field trip to see buildings, bedrock exposures of the Wasatch fault, geomorphic evidence of faulting, and areas having potential rockfall, landslides, and liquefaction problems.

REPORTS OF THE RESEARCH AND IMPLEMENTATION TRIADS

The reports prepared by each research and implementation triad are contained in this document. They are provided as a permanent record of the workshop. Individual papers are not part of the proceedings. They will be incorporated in a U.S. Geological Survey professional paper on the earthquake hazards of the Wasatch front. A preliminary copy of the manuscript is anticipated in 1987 and will be disseminated at the next workshop.

SUGAR HOUSE QUADRANGLE ATLAS

Atlas of maps illustrating the new technology represented by the Geographic Information System (GIS) is included in the report. This atlas demonstrates the kinds of applications that can and are being made.

\section{APPEND ICES}

Five appendices are included with this report. The first two are at the end of this section and describe Phase I (Appendix 1) and Phase II (Appendix 2) of the research and implementation work plan. The ot hers, Appendix A--Glossary of Terms Used in Earthquake Hazards Assessments; Appendix B--Strong Motion Instruments in Utah; and Appendix C--List of Participants In The Workshop, are located at the end of the report.

\section{ACKNOWLEDGMENTS}

The valuable contributions of the six triad groups is gratefully acknowledged. Carla Kitzmiller, Shirley Carrico, and Charlot te Jackson (USGS) provided excellent administrative support of the workshop, implemented the travel arrangements, and prepared the proceedings. 


\section{REFE RENCES}

Hays, W. W., and Gori, P. L. (Editors), 1984, Workshop on Evaluation of Regional and Urban Earthquake Hazards and Risk in the Wasatch Front area, Utah," Proceedings of Conference XXVI, U.S. Geological Survey Open-File Report 84$763,674 \mathrm{p}$.

Yin, Robert K., and Moore, Gwendolyn B., 1985, The Utilization of Research, Cosmos Corporation, Washington, D.C., 101 p. (Prepared for the Nationa1 Science Foundation). 


\author{
APPENDIX 1 \\ PHASE I \\ REGIONAL EARTHQUAKE HAZARDS ASSESSMENTS \\ WASATCH FRONT, UTAH \\ DRAFT WORK PLAN: FY 84-86
}

\title{
FOREWARD
}

This draft work plan describes the integrated goals, plans, and activities of the U.S. Geological Survey (USGS) and the Utah Geological and Mineral Survey (UGMS) for the program element, "Regional Earthquake Hazards Assessments: Wasatch front, Utah," a part of the Geological Survey's National Earthquake Hazards Reduction Program (NEHRP). The purpose of the work plan is to define research GUIDELINES and general RESPONSIBILITIES for 3-years, FY 84-86, the first phase of a focused effort on the Wasatch front. The work plan will be reviewed each year and revised, as appropriate, to reflect progress, new goals, opportunities for synergism, and more effective use of resources. The following persons participated in at least one of the two planning meetings held in Salt Lake City, Utah, on October 27-28, 1983, and January 26-27, 1984, and contributed to the formulation of the work plan:

Robert Alexander

Ted Algermissen Genevieve Atwood William M. Brown, III Robert Bucknam Russ Campbel1 West Dewsnup Ralph Findlay Douglas Gore Paula Gori Wendy Hassibe Walter Hays Bruce Kaliser Floyd Toren Klinge William Kockelman Don Mabey Jerry Olson Albert Rogers Robert Smith Arthur Tarr Lorayne Tempest Will Ulman

\author{
U.S. Geological Survey (National Mapping Division) \\ U.S. Geological Survey \\ Utah Geological and Mineral Survey \\ U.S. Geological Survey \\ U.S. Geological Survey \\ U.S. Geological Survey \\ Utah Division of Comprehensive Emergency Management \\ Utah Division of Comprehensive Emergency Management \\ Federal Emergency Management Agency \\ U.S. Geological Survey \\ U.S. Geological Survey (National Mapping Division) \\ U.S. Geological Survey \\ Utah Geological and Mineral Survey \\ Utah Division of Comprehensive Emergency Management \\ U.S. Geological Survey \\ Utah Geological and Mineral Survey \\ Federal Emergency Management Agency \\ U.S. Geological Survey \\ University of Utah \\ U.S. Geological Survey \\ Utah Division of Comprehensive Emergency Management \\ U.S. Geological Survey (National Mapping Division)
}

\section{HISTORICAL BACKGROUND}

The concept of the Regional Earthquake Hazards Assessments program element evolved out of discussions held at Asilomar Conference Center, Pacific Grove, California, in April 1982. At this meeting, 54 participants (27 USGS and 27 non-Survey) in the NEHRP were asked to debate the question "are changes in the NEHRP, now 5-years old, needed and if so what are they?" From these discussions, the 5 interrelated program elements constituting the current NEHRP were defined:

1) Regional Monitoring and Earthquake Potential--Perform geologic and seismological analyses of current earthquake activity including the 
seismic cycle of active faults and estimates of earthquake potential in earthquake-prone regions of the United States (23\% of budget).

2) Earthquake Prediction Research--Conduct, field laboratory, and theoretical studies of earthquake phenomena with the goal of reliable prediction of the time, place, and magnitude of damaging earthquakes ( $44 \%$ of budget).

3) Data and Information Services--Provide data on earthquake occurrence to the public, other Federal agencies, State and local governments, emergency response organizations, and the scientific community (12\% of budget).

4) Engineering Seismology--Operate a national network of strong motion instruments, disseminate the basic ground-motion information, and conduct research on the data ( $9 \%$ of budget).

5) Regional and Urban Earthquakes Hazards Evaluation--Compile and synthesize geologic and geophysical data needed for evaluating the earthquake hazards of ground-shaking, ground failure, surface fault rupture, and tectonic deformation and for assessing the risk in broad geographic regions containing important urban areas. Foster an environment for implementation, creating partnerships and providing high quality scientific information that can be used by local governments to devise and implement loss-reduction measures (such as building codes, zoning ordinances, personal prepardness, etc.) (12\% of budget).

\section{COMPONENTS OF THE REGIONAL AND URBAN EARTHQUAKE HAZARDS PROGRAM ELEMENT}

The Regional and Urban Earthquake Hazards program element has 5 INTERRELATED components :

1) Information Systems--The goal is to produce QUALITY data along with a comprehensive information system, available to both internal and external users for use in earthquake hazards evaluations, risk assessment, and implementation of loss-reduction measures.

2) Synthesis of Geological and Geophysical Data for Evaluation of Earthquake Hazards--The goal is to produce synthesis reports describing the state-of-knowledge about earthquake hazards (ground shaking, surface faulting, earthquake-induced ground failure, and tectonic deformation) in the region and to recommend future research to increase the state-of-knowledge required for the creation and implementation of loss-reduction measures.

3) Ground Motion Modeling--The goal is to produce deterministic and probabilistic ground-motion models and maps of the ground-shaking hazard with commentaries on their use.

4) Loss Estimation Models--The goal is to devise economical methods for acquiring inventories of structures and lifeline systems in urban areas, to create a standard model and commentary for loss estimation, and to produce loss and casualty estimates for urban areas. 
5) Implementation--The goal is to foster the creation and implementation of hazard-reduction measures in urban areas, providing high-quality scientific information that can be used by local government decisionmakers as a basis for "calling for change."

Research focusing on one or more of the above components is presently being conducted in the following urban areas, ranked according to their respective priority:
1) Wasatch front, UT
3) Northern California
5) Mississippi Valley
7) Charleston, SC
2) Southern California
4) Anchorage, $\mathrm{AL}$
6) Puget Sound, WA
8) Buffalo-Rochester area, NY

The Wasatch front is the only region where all 5 components are being conducted. In each region, the research is performed using the resources of the USGS's internal and external program (the external program is implemented through grants and contracts awarded annually following a request for proposals in cooperation with the resources of their "partners"). The goal is to achieve maximum synergism of State and Federal resources.

STRATEGIES FOR CONDUCTING RESEARCH IN THE WASATCH FRONT AREA

The strategies for the Wasatch front are:

1) Foster Partnerships--USGS and UGMS will seek to foster strong partnerships with the universities, private sector, units of local government, and other State and Federal agencies. Existing partnerships will be strengthened.

2) Take Advantage of Past Research Studies and Other Activities--Results of past research studies will be utilized to the fullest extent possible. Achievements of the Utah Seismic Safety Advisory Council, the USGS sponsored earthquake hazards workshop of 1980, and the Governor's Conference on Natural Hazards of 1983 will be used as building blocks for future activities.

3) Study 10 Counties Along the Wasatch Front--Although Salt Lake, Davis, Weber, and Utah Counties will receive the primary attention because of their population density, potential risk, and the availability of information from prior and ongoing research studies, Cache, Box Elder, Summit, Wasatch, and Juab Counties will also be studied. The goal is to acquire a uniform, HIGH QUALITY data base on earthquake hazards.

4) Convene Annual Meetings to Review Progress and Recommend New ResearchEach year, a workshop will be held in Salt Lake City to review: WHAT HAS BEEN ACCOMPLISHED and WHAT IS STILL NEEDED TO ACCOMPLISH THE GOALS. Participants from many different disciplines in the workshop will be asked to address the question "what changes, if any, are needed to accomplish the goals of the program element "Regional Earthquake Hazards Assessments: Wasatch front, Utah."

5) Publish Annual Reports and Communicate Findings--Proceedings of the workshops, which will include papers documenting results from all 
research projects in the Wasatch front, will be published as USGS

Open-File Reports approximately 3- or 4-months after each meeting. In FY 86, the third year of the program, a USGS Professional Paper will be published. The workshops, their products, and the findings in the professional paper will be COMUNICATED to policymakers whose task is to implement hazard-reduction policy.

6) Take Advantage of Earthquakes--Use knowledge gained from earthquakes such as the Borah Peak, Idaho, earthquake of October 1983 to improve the methodology that is currently used in the evaluation of earthquake hazards and the assessment of risk in the Wasatch front area. Many scientists consider the 1983 Borah Peak earthquake as representative of the type of earthquake that can occur along the Wasatch front. In addition, other parts of the World have a similar tectonic setting as the Wasatch front; earthquakes in these areas should be investigated to provide insight into the characteristics of ground-shaking and the physical effects that might occur in a major earthquake along the Wasatch front. 


\section{RESEARCH GOALS, OBJECTIVES, AND TASKS OF THE PROGRAM ELEMENT "REGIONAL EARTHQUAKE HAZARDS ASSESSMENTS: WASATCH FRONT, UTAH"}

\section{INTRODUCTION}

The 5 INTERRELATED components comprising the program element "Regional Earthquake Hazards Assessments: Wasatch front, Utah" are described below to provide GUIDELINES for researchers who are either working now or planning to work in the Wasatch front area. Each component of the workplan will be reviewed annually and revised as appropriate, to meet the research goals of the program element. UGMS (and their partners) will focus primarily on tasks described in components 1,2, and 5. USGS (and their partners) will focus on tasks described in components 1-5.

\section{COMPONENT 1: INFORMATION SYSTEMS}

Every research study will generate basic data which needs to be organized. A large but unorganized amount of data relating to the earthquake hazards along the Wasatch front already exists in published maps, reports, and computerized data sets. If these data were organized, the resultant data base would be an extremely valuable resource for a wide variety of user groups, including the participants in the NEHRP. In addition, the data base is expected to grow as research studies mature.

The objectives of this component are: 1) to make quality data readily available to meet the needs of researchers and policymakers, 2) to create a system that assures that new data will be available in the form most useful to meeting program objectives, 3) to devise a system whereby potential users will have easy access to data in media, scales, and formats that will be most useful to them, and 4) to provide continuing information on objectives and progress of the program element. Accomplishing these objectives will require: 1) inventorying existing data sets, 2) developing data standards for critical data sets, 3) identifying user groups and their needs, 4) developing strategies for data management and data dissemination, and 5) assuring that pertinent hazards data are available to the user community.

Priorities--The first priority is the creation of a directory of hazards information by the time of the 1984 annual workshop. Second priority is an inventory of existing data sets, perhaps using a standard questionnaire or form. Third priority is to test the capability for data interchange and communications.

Implementation--The objectives listed above will be accomplished primarily by USGS and UGMS. Tarr (USGS) and Mabey (UGMS) will provide leadership; however, others will be involved in the implementation of the tasks. To accomplish the above objectives, a leadership role is suggested for USGS and UGMS, as noted below in the task statements:

1) Inventory of Existing Data--UGMS lead. The UGMS is compiling a computerized bibliography of Utah geology that provides for keyword searches, including terms that are pertinent to the evaluation of earthquake hazards and the assessment of risk. The bibliography will be upgraded by the UGMS to meet the needs of the program element. 
USGS lead. USGS will compile a directory of hazards information to determine what data exists, what form the data are in, and the availability of the data. A determination will be made of each data set as to its adequacy for the needs of the research program.

2) Standardization--USGS lead. To the extent possible, the catalog of Utah earthquakes (especially the preinstrumental data) will be standardized because it is important, if not crucial, to several of the research studies. The catalogs of the University of Utah Seismograph Station and the USGS (National Earthquake Information Service, Algermissen) are the best starting point. Standards may need to be established for other major data sets, such as computer files of digitized geological data.

UGMS lead. Part of this effort will be the selection of standard base maps and mapping scales for data compilation and publication by all participants in the program. Reproducible base materials must be available for rapid production of greenlines, paper copies, and film composites of maps. In addition, standards for computer storage of point data and line data will have to be established if automated computer mapping is to be realized.

3) Data Set Management--UGMS lead. A complete library of publications, reports, and a hard copy of data sets related to the Wasatch front studies are needed. These could be established as a part of the existing UGMS library.

USGS lead. The successful management of computerized data should expedite many research studies. Existing computer resources are the USGS VAX/VMS system in Golden, the Multics system in Lakewood, USGS PIO in Salt Lake City, and the Utah Department of Natural Resources Automatic Geographic Reference System in Salt Lake City. The University of Utah Computer Center and the NOAA data center in Boulder are other systems that may have to be accessed. Documented software to access and utilize the major data sets must also be available.

4) Information Transfer--UGMS lead. An earthquake information office is needed in Salt Lake City. Such an office would be concerned primarily with the dissemination of earth science information (e.g., in a quarterly newsletter) related to the earthquake hazards of ground-shaking, surface rupture, ground failure, and tectonic deformation, as well as earthquake preparedness. The office would provide, to a wide variety of users: historic and current data on Utah earthquakes, information on current research, and advice on obtaining access to earthquake-related literature and data. The new earthquake information office could be established at the UGMS, with a close working relationship with the USGS Public Inquiries office in Salt Lake City.

COMPONENT 2: SYNTHESIS OF GEOLOGIC AND GEOPHYSICAL DATA FOR EVALUATION OF EARTHQUAKE HAZARDS

Geologic and geophysical research aimed at a better understanding of the potential for the occurrence of large, damaging earthquakes in the Wasatch front region have been carried out since as early as 1970. These studies have provided 
a critical perspective on the level of the potential hazard for the region and have contributed, in large part, to the high priority given to this area in the Regional and Urban Earthquake Hazards program element. The geologic and geophysical data collected in these studies are essential in the evaluation of earthquake hazards and the assessment of risk from earthquakes occurring in the region. However, the results of these studies have been released primarily as discrete scientific papers in research journals or in the "gray" literature of USGS open-file reports and other publications. They have not been synthesized or integrated into a comprehensive evaluation of the potential for the occurrence of damaging earthquakes and the associated hazards of ground-shaking, ground failure, surface fault rupture, and tectonic deformation in the Wasatch front region.

Priorities--First priority will be given to collecting and synthesizing basic geologic and geophysical data required for evaluation of earthquake hazards. The second priority is to conduct additional research needed to achieve the goals of the program element.

Implementation--USGS and UGMS scientists (identified below) will provide leadership and perform the research tasks identified below. In addition, other researchers in universities and the private sector (e.g. University of Utah, Utah State University, and others) will participate under the auspices of the USGS's grants and contracts program.

1) Collection and Synthesis--Research initiated in prior years will be continued as well as new research, focusing on the collection and synthesis of those data needed for realistic deterministic and probabilistic calculations of hazard and risk for the region, as well as carrying out essential additional research. This effort will be integrated to provide: a) a broader understanding of the setting and effects of active tectonic processes and rates of tectonic activity producing earthquakes in the region, and b) definition and study of specific geologic hazards of special significance to the Wasatch front area.

The objective of the above task is to develop synthesis reports and maps on four main topics. Project chiefs in USGS and UGMS are listed below for each topic:

a. Geologic/tectonic setting of current seismicity of the Wasatch front region:

Project Chief/Investigator Project Topic

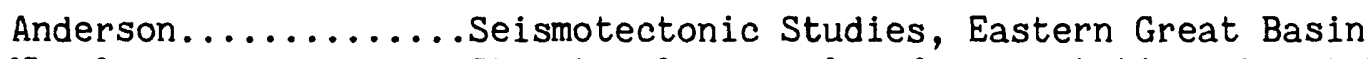
Wheeler................ Structural controls of segmentation, Wasatch Front

Pakiser............ Review and evaluation of crustal models Basin and Range Province

Diment...............eophysics of eastern Great Basin Transition Zone

Mabey (UGMS).......... Interpretation of subsurface and geophysical data (Utah Valley to Ogden area) 
2) Late-Quaternary tectonic activity of the Wasatch front region:

Project Chief/Investigator Project Topic

Crone............. Subsurface geometry of Late-Quaternary
faults, Wasatch front region.
Machette/Rehis........ Late Quaternary history of the Wasatch
fault in the Santaquin-Nephi region.
Wood.............. Tectonic deformation, Wasatch front region
Kaliser (UGM)...... Documentation of evidence of Late-Quaternary
faulting in Wasatch front urban area

3) Timing and character of Late-Quaternary ground failure events:

Project Chief/Investigator $\quad$ Project Topic

Madole.............Timing of ground failure events, Wasatch

front region

Not assigned.......... Liquefaction potential mapping

Not assigned........... Surface faulting

Not assigned........... Slope stability mapping

Bucknam..............Seismic source zone mapping

4) Information for local and regional use in hazard reduction:

Project Chief/Investigator $\quad$ Project Topic

Not assigned (UGMS)....... Compilation of hazards information for local and regional use

\section{COMPONENT 3: GROUND MOTION MODELING}

This component is concerned primarily with the prediction of the effects of local geologic site conditions on ground shaking in the Salt Lake City region, although the effects of the source and the travel path will also be considered. Knowledge of the nature and severity of ground motion induced at a site is fundamental to sound earthquake-resistant design. Although the importance of local geologic conditions has been recognized for many years, the quantitative prediction of their influence on ground shaking using either empirical or theoretical models is still evolving. In this component, the application, extension, and validation of relevant research techniques will be continued in the Salt Lake City area and along the Wasatch front.

Priorities--The first priority is to install strong motion accelerographs in the Salt Lake City area and to acquire and use the mini-Sosie portable reflection system in ground-response research. (Utah only has one strong motion accelerogram from past earthquakes.) The second priority is to prepare a synthesis report of the ground shaking data available from prior studies in Utah. The third priority is to extend the results of these studies, performing deterministic and probabilistic hazard analysis and utilizing new equipment (mini-Sosie, strong motion accelerographs, etc.) to acquire basic data.

Implementation--The research will be conducted primarily by Algermissen, Campbell, Hays, Rogers, and King (USGS). Non-USGS researchers will be invited to 
participate through the Survey's external grants and contract program. The tasks are described below:

1) Synthesis Report--The research by Hays, King, and Miller, which used nuclear-explosion ground-motion data to derive ground response in the Salt Lake City-Ogden-Provo-Logan-Cedar City area, has been published in several journals (e.g., Proceedings of Third International Conference on Seismic Microzonation), but has not been synthesized and published in a reference that is more readily available. Such a report will be produced in FY 84. A USGS Open-File report describing the nuclear-explosion ground-motion data will also be produced.

2) Deterministic and Probabilistic Hazard Analysis--Research on deterministic and probabalistic hazard analysis, applied in 1982 on a national scale by Algermissen and others, will be applied in the Wasatch front urban areas, and extended by using time-dependent models of earthquake occurrence. A regional seismic wave attenuation function for Utah will be derived. These analyses, combined with the inventory and vulnerability studies discussed below in the loss estimation component, will form the basis for estimates of economic loss (risk) and casualties.

3) Research on Attenuation and Ground Response--Beginning in late FY 84, the methodology developed by Rogers and others to zone the ground-shaking hazard in Los Angeles will be applied to the Wasatch front. This empirical technique uses several generally available geotechnical factors to predict how site conditions will influence ground motion during an earthquake. Sites are classified into site types or clusters according to their geotechnical factors, and a mean ground shaking factor (dependent on the site's cluster type) is assigned to the site in three separate period bands. The classification scheme developed for Los Angeles will be applied to Salt Lake City. Validation of this technique for Salt Lake City will be accomplished by comparing ground motions recorded by Hays and others in Salt Lake City with the predictions. By combining and comparing the cluster results at selected sites throughout the city with mapped near-surface geology, maps of the ground-shaking response relative to rock can be constructed for each of the three period bands on a regional basis. These results will also be used to construct intensity maps for a maximum-magnitude earthquake. Ground-response research is still in the early stages, and as noted by Rogers and others, some sites outside of Los Angeles can not be classified using the scheme developed for that city. Additional site types may have to be developed in this study; these clusters might possibly be based on the data of Hays and others. Additional ground motion data, however, may have to be collected, as well as the development of new correlation techniques and the collection of new site properties.

Regional seismic-wave attenuation functions for the Wasatch front will be derived using the best available data.

4) Zoning Research--Beginning in FY 85, research with high frequency techniques (e.g., mini-Sosie) will be initiated to determine subsurface conditions within the study area that are known to exhibit high ground response. For example, in the Los Angeles study near-surface velocity contrasts in the depth range of 10-20 meters were found to cause the 
highest levels of ground response for buildings that are in the 2- to 5story class. Buildings having more than 5-stories were also found to be at greatest risk when located at sites where the depth to basement is the greatest. Because reflection techniques may provide the only means to define the important subsurface factors controlling site response in some urban areas, experiments will be conducted in Salt Lake City and Los Angeles at sites where measured site response can be correlated with reflection data.

5) Probabilistic Ground Shaking Hazard Maps Incorporating Ground Response-Following tasks 1-4, described above, revised estimates of the probabilistic ground-shaking hazard in the Salt Lake City region will be made. Maps of the peak acceleration and intensity will be prepared for exposure periods of 10,50 , and 250 years. These maps will incorporate the effects of local geologic conditions.

COMPONENT 4: LOSS ESTIMATION MODELS

In this component all available hazards data will be used in the development of economic loss ( $\mathrm{risk}$ ) and casualty estimates. Estimates of probable losses and casualties in an earthquake are important results. Loss estimates provide a scientific basis for land-use planning, an economic basis for the implementation of suitable building codes, and form the framework for disaster mitigation, preparedness, and relief programs. A considerable amount of research on loss estimation (seismic risk) has already been done in the Wasatch front area by USGS and its consultants. An earthquake vulnerability study was completed in 1976 (Rogers, et al 1976) to provide planning guidance for earthquake preparedness and mitigation. Preliminary estimates of economic losses using three different loss models for Salt Lake City have recently been published (Algermissen and Steinbrugge, 1984).

Priorities--The first priority is to update the existing building inventory in Salt Lake City (especially considering high rise buildings) and to create an inventory for lifeline systems. The second priority is to establish building inventories and lifeline system inventories in other parts of the study area, seeking to achieve uniformity with the Salt Lake City inventories. The third priority is to reassess the vulnerability relationships for Utah.

Implementation--The research will be conducted primarily by Algermissen (USGS). Non-Survey researchers will be invited to participate through the USGS's external grants and contract program. The tasks are described below:

1) Loss Estimation, Salt Lake City-Odgen-Provo--Beginning in FY 84 , the primary emphasis will be placed on research concerning earthquake loss (risk) studies is the Salt Lake City, Ogden, and Provo metropolitan areas. The data requirements are: 1) update the existing building inventory in Salt Lake City, 2) develop an inventory of buildings in other parts of the study area, 3) reassess vulnerability relationships for Utah, utilizing new data from the 1983 Coalinga, California, earthquake and data obtained from additional review and analysis of the 1971 San Fernando, California, earthquake, and 4) develop additional data on the distribution and vulnerability of lifeline systems in the Salt Lake City-Ogden-Provo areas. 
Deterministic loss and casualty estimates will be made for magnitude $\left(M_{S}\right)$ 6.5 and 7.5 earthquakes having various locations on the Wasatch fault. Probabilistic loss and casualty estimates will be computed for exposure times of interest of 10,50 , and 250 years at the 90 percent probability level. Both deterministic and probabilistic loss estimates will be based on appropriate ground motion hazard maps which, where possible, will include site response (see above discussion of ground motion modeling). The loss estimates will also include, where possible, losses associated with the geologic effects of earthquakes such as liquefaction. Total economic losses will be estimated and, in addition, losses by class of construction and the vulnerability. In general, the classes of construction used will be based principally on their framing system. Casualty estimation will require additional data on building occupancy.

2) Loss Estimation, Other Parts of the Study Area--To the extent possible, the same data identified in task 1 above will be acquired in other counties in Utah and used to perform loss estimates.

\section{COMPONENT 5: IMPLEMENTATION}

The goal of this component is effective use of scientific information to reduce loss of life and damage to property caused by earthquake hazards as well as by other geologic and hydrologic hazards. Successful achievement of the goal requires COMUNICATION Of TRANSLATED SCIENTIFIC INFORMATION to RESPONSIBLE OFFICIALS and INTERESTED PARTIES seeking to REDUCE HAZARDS by use of one or more REDUCTION TECHNIQUES. These aspects of the problem and its solution will be discussed below, providing a framework for an integrated work plan involving all concerned parties and guidelines for proposals to the USGS's external grants and contracts program.

Priorities--The first priority is to determine the needs of users in Utah for earthquake hazards information. The second priority is to produce translated (i.e., interpreted information derived from basic scientific data) scientific information that meets the needs of these user groups. The third priority is to foster an environment for implementation of research results by local governments, utilizing workshops, training classes, questionnaires and other procedures to communicate the scientific information.

Implementation--Leadership for the implementation components will be provided by Atwood and Mabey (UGMS) and Gori, Hays, and Kockelman (USGS). One objective of this component is to make it easy for local government, engineers, architects, planners, emergency preparedness planners, and emergency responders to use the technical information generated in this program. A key strategy is to build on past successful activities such as the Utah Seismic Safety Advisory Council (1977-1980) and the "Governor's Conference on Geologic Hazards" (August 1983). Partnerships between the research community (USGS, UGMS, universities, and the private sector) and those who will ultimately use the information to implement hazard-reduction plans are necessary for success, and the strongest possible effort will be made to achieve these partnerships within the initial three years. However, implementation activities, described below, must continue after the Wasatch front is no longer receiving first priority in the Survey's "Regional Earthquake Hazards Assessments program element". 
1) Scientific Information--This task began before FY 84 because many prior studies (e.g., conducted by the University of Utah, Utah State University, Woodward Clyde Consultants, USGS, UGMS, and others) have produced considerable high-quality information. Translated scientific information is a prerequisite to its transfer to a user and its use in a loss-reduction measure or technique. While a great deal of scientific information can be used directly by engineers or other scientists, some information must be translated to enhance its understanding and effective use by nonscientists. Such translated information includes: faultrupture location with forecasts of recurrence intervals and anticipated displacement, liquefaction with levels of susceptibility, areas of landslide hazard with levels of susceptibility, areas of inundation caused by hypothetical dam failures, and areas of building failures caused by ground shaking. The following actions are likely to improve use of scientific information by nonscientists:

-- Identify and catalog existing hazard maps and reports.

-- Identify the hazard maps and reports needed for hazard-reduction measures.

-- Estimate cost and determine responsibility, funding, and delivery of the information that can be provided.

-- Assure that new information is prepared in detail and at the scales needed by the users (see Table 1).

-- Make special efforts to present the information in a format and language suitable for use by engineers, planners, and decisionmakers.

-- Assure that information (including discoveries, advances, and innovative uses) is released promptly through appropriate communicators and communication techniques (see Tables 2 and 3 ).

2) Communication--This task is also a continuation of past activities. Communication of scientific information consists of both its transfer and its effective use for hazard reduction. Examples of communicators and communication techniques are listed in Tables 2 and 3 . The following actions are likely to improve effective use of the technical information:

-- Design the communications program after an assessment of potential users' needs and capabilities.

-- Select the most effective educational, advisory, and review services (Table 2) appropriate to the targeted users.

-- Design the communications program so that information can be effectively disseminated (including use of the scientists and investigators to help communicate).

3) Determine Users' Needs--The past work by the Utah Seismic Safety Advisory Council (1977-1980) and the August 1983 Governor's Conference on geologic hazards succeeded to some extent in determining the needs for earthquake hazards information in Utah. Use of scientific information by 
nonscientists requires a considerable effort on the part of both the producers and the users to communicate with each other, and although a variety of users exist, effective use depends upon the users' interests, capabilities, and experience in hazard reduction. Examples of users are listed in Table 1. The following actions will ensure effective transfer of the information to potential users:

-- Identify and target users (Table 1) that have urgent needs and who could be expected to use the information most effectively.

-- Consult with those users about their needs and priorities and prioritize the information needed.

-- Monitor and analyze the enactment of local, State, and Federal hazard-reduction laws or regulations and the issues that affect users in order to anticipate and respond to their needs.

-- Encourage users--both public and private--to develop an in-house capability to obtain and apply the information (including risk assessment).

-- Orient or train targeted users in order to enable them to understand and to use the information effectively.

4) Reduction Techniques--This task must also build on past activities. Many opportunities are available for reducing geologic and hydrologic hazards. Examples of hazard-reduction techniques are listed in Table 4. The following actions will increase the likelihood of an effective reduction of hazards:

-- Identify the most effective reduction techniques that are either being used by the targeted users or are available to them.

-- Review existing State programs or laws that could incorporate such reduction techniques and recommend changes or new programs and laws.

-- Devise and test innovative reduction techniques.

5) Evaluation--Continuing systematic evaluation will be a part of this program and is a key to any successful state-local hazard reduction program. An inventory of uses made of the scientific information, interviews with users, and an analysis of the inventory and responses will result in identifying new users, and any obstacles to communication of the information or its effective use. The following actions will make evaluation easier and enhance implementation:

-- Inventory uses of information (Table 4) to identify and document the type and number of uses of each hazards map or report.

-- Analyze uses of the hazards information and any problems identified and suggest improvement to the information or to the communication techniques.

-- Identify problems with and suggest improvements to reduction 
techniques by the monitoring of land-use decisions.

-- Interview users of information (Table 1) to evaluate the adequacy of the information and the communication techniques and to identify obstacles to their effectiveness.

Proposed-Selection Criteria--Numerous combinations of scientific information, communication techniques, users, and reduction techniques exist. Consideration of the following factors will be helpful in the selection of proposals for grants and contracts in support of the above implementation tasks:

-- User is an applicant.

-- Experienced communicator is an applicant.

-- A high probability exists for successful transfer and effective use of the information.

-- A communicator is in place and communication technique are in operation.

-- Translated scientific information is immediately available to the user.

-- Minimum time is required for translation and transfer of the information.

-- A large number of people or numerous critical facilities are at risk in the targeted area.

-- Rapidly urbanizing areas are located in the targeted area.

-- An opportunity exists for innovative or prototypical communication or reduction techniques.

-- Sponsor, convene, and coordinate at least one workshop each year designed to foster an environment for implementation of loss reduction measures at the local level.

-- Evaluate proposals and fund selected projects that will enhance implementation.

-- Enlist Federal partners.

Suggested Roles for UGMS--Initially, the role of the UGMS would be to:

-- Advise the USGS on the selection of projects that will enhance implementation.

-- Serve as a technical advisor and reviewer of funded implementation projects.

-- Enlist partners in Utah. 
Some Potential Users of Geologic and Hydrologic Information for Earthquake-Hazard Reduction along the Wasatch Front, Utah

City, County, and Area wide Government Users

City building, engineering, zoning, and safety departments County building, engineering, zoning, and safety departments Mayors and city council members

Multicounty planning, development, and preparedness agencies

Municipal engineers, planners, and administrators

City and county offices of emergency services

Planning and zoning officials, commissions and departments

Police, fire, and sheriff's departments

Public works departments

County tax assessors

School districts

\section{State Governments Users}

Department of Community and Economic Development (Community Services Office, Economic and Industrial Development)

Department of Business Regulation (Contracts Division, Real Estate Division)

Department of Financial Institutions

Department of Health (Environmental Health, Health Care Financing)

Department of Natural Resources

Department of Transportation

Division of Comprehensive Emergency Management

Division of Water Resources

Division of Water Rights

Facilities Construction and Management

Geological and Mineral Survey

Governor's Office

Legislative Fiscal Analyst

Legislative Research and General Counsel

National Guard

Planning and Budget Office

Public Service Commission

Science Advisor

State Tax Commission 


\title{
Federal Government Users
}

\author{
Army Corps of Engineers \\ Bureau of Land Management \\ Bureau of Reclamation \\ Congress and Congressional staffs \\ Department of Agriculture \\ Department of Energy \\ Department of Housing and Urban Development \\ Department of Interior \\ Department of Transportation \\ Environmental Protection Agency \\ Farmers Home Administration \\ Federal Emergency Management Agency \\ Federal Housing Administration \\ Federal Insurance Administration \\ Federal Power Commission \\ Forest Service \\ General Services Administration \\ Geological Survey \\ National Bureau of Standards \\ National Oceanic and Atmospheric Administration \\ National Park Service \\ National Science Foundation \\ Nuclear Regulatory Commission \\ Small Business Administration \\ Soil Conservation Service
}

Other National Users

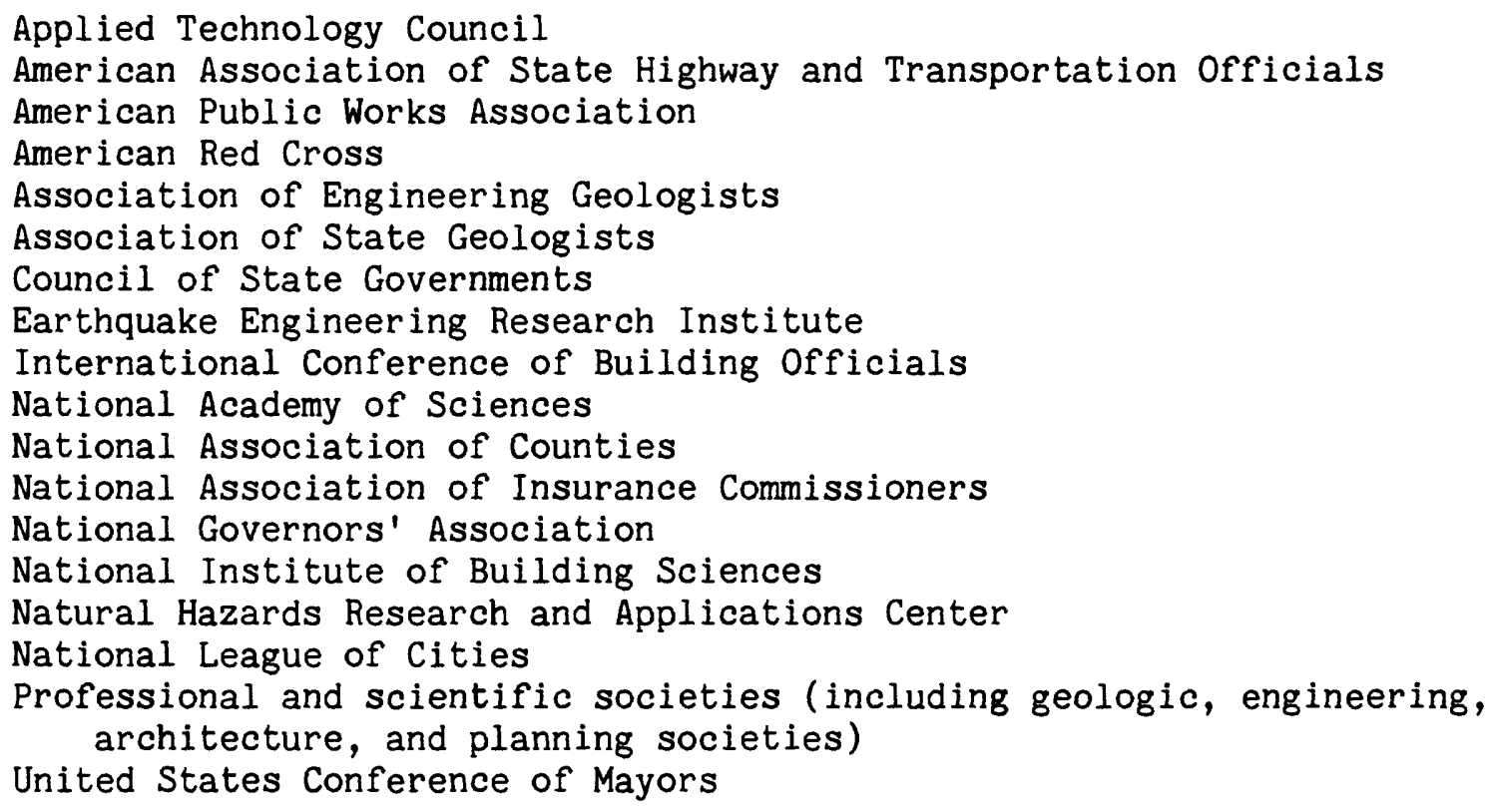


Private, Corporate, and Quasi-public Users

Civic and voluntary groups

Concerned citizens

Construction companies

Consulting planners, geologists, architects, and engineers

Extractive, manufacturing, and processing industries

Financial and insuring institutions

Landowners, developers, and real-estate persons

News media

Real-estate salespersons

Utility companies

University departments (including geology, civil engineering, architecture, urban and regional planning, and environmental departments). 
Table 2

Typical Communication Techniques

Educational services

Assisting and cooperating with universities and their extension divisions in the preparation of course outlines, detailed lectures, casebooks, and display materials.

Contacting speakers and participating as lecturers in regional and community educational programs related to the application of hazard information.

Sponsoring, conducting and participating in topical seminars, conferences, workshops, short courses, technology utilization sessions, cluster meetings, innovative transfer meetings, training symposia, and other discussions with user groups, e.g. 1983 Utah Governor's Conference on Geologic Hazards, UGMS Circular 74.

Releasing information needed to address critical hazards early through oral briefings, newsletters, seminars, map-type "interpretive inventories," open-file reports, reports of cooperating agencies, and "official use only" materials.

Sponsoring or cosponsoring conferences or workshops for planners and decisionmakers at which the results of hazard studies are displayed and reported on to users, e.g. scheduled USGS workshop, August 1984.

Providing speakers to government, civic, corporate, conservation, and citizen groups, and participating in radio and television programs to explain or report on hazard-reduction programs and products.

Assisting and cooperating with regional and community groups whose intention it is to incorporate hazard information into school curricula.

Preparing and exhibiting displays that present hazard information and illustrate their use in hazard reduction.

Attending and participating in meetings with local, district, and state agencies and their governing bodies for the purpose of presenting hazard information.

Guiding field trips to potentially hazardous sites.

Preparing and distributing brochures, TV spots, films, and other visual materials to the news media.

\section{Advisory services}

Preparing annotated and indexed bibliographies of hazard information and providing lists of pertinent reference material to various users.

Assisting local, State, and Federal agencies in designing policies, procedures, ordinances, statutes, and regulations that cite or make other use of hazard information.

Assisting in recruiting, interviewing, and selecting planners, engineers, and scientists by government agencies for which education and training in hazard information collection, interpretation, and application are criteria, e.g. pending proposal to fund county geologists.

Assisting local, State, and Federal agencies in the design of their hazard information collection and interpretation programs and in their work specifications.

Providing expert testimony and depositions concerning hazard research information and its use in reduction techniques. 
Assisting in the presentation and adoption of plans and plan-implementation devices that are based upon hazard information.

Assisting in the incorporation of hazard information into local, State, and Federal studies and plans.

Preparing brief fact sheets or transmittal letters about hazard products explaining their impact on, value to, and most appropriate use to local, State, and Federal planning and decisionmaking.

Assisting users in the creation, organization, staffing, and formation of local, State, and Federal planning and planning-implementation programs so as to assure the proper and timely use of hazard information.

Preparing and distributing appropriate user guides relating to earth hazard processes, mapping, and hazard-reduction techniques, e.g. UGMS fliers.

Preparing model State safety legislation, regulations, and development policies.

Preparing model local safety policies, plan criteria, and plan-implementation devices.

\section{Review services}

Review of proposed programs for collecting and interpreting hazard information.

Review of local, State, and Federal policies, administrative procedures, and legislative analyses that have a direct effect on hazard information.

Review studies and plans based on hazard information. 
Representative Communicators of Hazard Information

American Institute of Architects/Research Corporation

American Institute of Certified Planners, Utah Chapter

American Institute of Professional Geologists, Utah Chapter

American Society of Public Administrators, Utah Chapter

American Society of Civil Engineers, Utah Chapter

Association of Engineering Geologists, Utah Chapter

Bear River Association of Governments

Children's Museum

Church groups, church organizations, and church-sponsored events

Circuit riders (regional or project area)

City Management Association

Civic and voluntary groups

Community planning assistance programs

Council of State Governments

County extension agents

Educators (university, college, high school, and elementary school levels)

Governor's Advisory Council on Local Governments

Hansen Planetarium

Hazard-information clearinghouse (national, regional, or project area)

Hazard researchers, interpreters, and mappers

International Conference of Building Officials, Utah Chapter

Journalists, commentators, and editors, and their professional associates

Local seismic safety advisory groups

Mountain Lands Association of Governments

Museum of Natural History

National Council of State Legislators

National Governor's Conference

Neighborhood associations

Public information offices (Federal and State)

Researchers, engineers, and planners

Speakers bureaus (regional or project area)

Society of American Foresters, Wasatch Front Chapter

Urban and Regional Information Systems Association

University of Utah Seismograph Stations

Utah Association of Counties

Utah Geological Association

Utah League of Cities and Towns

Utah Geological and Mineral Survey

United States Conference of Mayors

U.S. Bureau of Land Management

U.S. Forest Service

U.S. Geological Survey

U.S. Soil Conservation Service

Wasatch Front Regional Council

Western Governor's Policy Office 
Table 4

Some Opportunities for Using Geologic and Hydrologic Information to Reduce Earthquake Hazards along the Wasatch Front, Utah

Preparing development studies and plans

Circulation of transportation studies or plans

Community facility and utility inventories or plans

Environmental impact assessments ind reports

Land-use and open-space inventories or plans

Land subdivision lot layouts

Multi-hazards inventories, risk analyses, and response capabilities Natural-hazards reduction plans

Redevelopment plans (pre- and post-earthquake)

Seismic safety and public safety plans

Discouraging new or removing existing unsafe development

Capital-improvements expenditures

Costs of insurance

Disclosing hazards to real-estate buyers

Financial incentives and disincentives

Governor's executive orders

Policies of private lenders

Non-conforming use provisions in zoning ordinances

Posted warnings of potential hazards

Public acquisition of hazardous areas

Public facility and utility service policies

Public information and education

Recording the hazard on public records

Removing unsafe structures

Special assessments or tax credits

Regulating development

Building ordinances

Design and construction regulations

Grading regulations

Hazard-zone investigations

Land-use zoning districts and regulations

Special hazard-reduction ordinances

Subdivision ordinances

Designing and building structures

Strengthening or retrofitting of unsafe structures

Critical facilities, siting, design, and construction

Engineering, geologic, and seismologic reports

Public-facility or utility reconstruction or relocation

Reconstruction after earthquakes

Repair of dams

Site-specific investigations and hazard evaluations 
Preparing for and responding to disasters

Anticipating damage to critical facilities

Damage inspection, repair, and recovery procedures

Dam and reservoir supervision

Disaster training exercises

Earthquake-prediction response plans

Earthquake-preparedness plans

Emergency response plans

Monitoring and warning systems

Relocating occupants of exceptionally hazardous buildings 


\author{
DRAFT WORK PLAN: PHASE II \\ REGIONAL EARTHQUAKE HAZARDS ASSES SMENTS \\ OF RESEARCH AND IMPLEMENTATION ALONG THE WASATCH \\ FRONT, UTAH: FY 87-88
}

FOREWORD

This draft work plan describes the integrated goals, plans, and activities of the U.S. Geological Survey (USGS), the Federal Emergency Management Agency (FEMA), Utah Geological and Mineral Survey (UGMS), and Utah Division of Comprehensive Emergency Management (CEM) for the second phase of USGS's program element, "Regional Earthquake Hazards Assessments," Wasatch front area." This program element is a part of the National Earthquake Hazards Reduction Program (NEHRP). The first phase of research and implementation had a duration of 3-years, beginning in October 1983, and focused main1y on: 1) the development of technical data bases and knowledge and 2) identification of strategies to foster implementation of earthquake 1 oss-reduction measures by a wide range of actual and potential user groups. Identification of user groups and their needs was an integral part of Phase I.

Substantial progress was realized in the first phase of research and implementation along the Wasatch front. Six triad teams prepared summary reports in July 1986 giving: 1) the status of the research and implementation in Utah after 3 years of concentrated effort and 2) suggestions for priority actions in the second phase. The triad reports, the draft work plan for research and implementation in Phase I, and the proceedings of the 1984 workshop, constitute the basis for this work plan.

The following individuals contributed to this draft work plan, either by providing input (for example, the triad teams) or by joining in the discussions held in Salt Lake City on September 29-30, 1986.

Loren Anderson

Walter Arabasz

Genevi eve Atwood

Jarold Barnes

Ear $1 \mathrm{Brabb}$

Robert Brown

Gary Christenson

Paula Gori

Walter Hays

Gary Johnson

Jef frey Keaton

Bill Kockelman

Michael Lowe

Bi11 Lund

Don Mabey

Michael Machette

Joe Moore

Craig Nelson

Jer ome 0akley

Jerry 01son

Lawrence Reaveley

\author{
Ut ah State University \\ University of Utah \\ Ut ah Geological and Mineral Survey \\ Salt Lake City Planning Commission \\ U.S. Geological Survey \\ U.S. Geological Survey \\ Ut ah Geological and Mineral Survey \\ U.S. Geological Survey \\ U.S. Geological Survey \\ Federal Emergency Management Agency \\ Dames and Moore \\ U.S. Geological Survey \\ Weber-Davis Count $i$ es \\ Ut ah Geological and Mineral Survey \\ Ut ah Geological and Mineral Survey \\ U.S. Geological Survey \\ West Valley Planning Department \\ Salt Lake County \\ Federal Emergency Management Agency \\ Federal Emergency Management Agency \\ Reaveley Enginee rs
}


Robert Robinson

Al bert Rogers

Lorayne Tempest

Jim Tingey

Del bert Ward

Les Youd
Utah County

U.S. Geological Survey

Ut ah Division of Comprehensive Emergency Man agement

Utah Division of Comprehensive Emergency Man agement

Structural Facilities, Inc.

Brigham Young University

COMPONENTS OF RESEARCH AND IMPLEMENTATION IN PHASES I AND II

In Phase I, the emphasis was placed on the simultaneous development of 5 interrelated components:

1) Development of information systems

2) Synthesis of new and existing geological and geophysical data needed for the evaluation of earthquake hazards of ground shaking, surface fault rupture, earthquake-induced ground failure, and regional tectonic deformation.

3) Ground Motion Models

4) Loss Estimation Mode1s

5) Fostering the implementation process and definition of user needs.

Figure 1 shows the perceived current status of these activities (with some grouping of components) along with the projected goals for 1990. Uncertainity bands are added to reflect the fact that certain research tasks have not been completed to the point that results can be utilized without some controversy.

In Phase II, all of the above components will have some tasks and the same goals will be pursued in varying degrees using internal and external programs funded by USGS as the primary stimuli. However, the principal emphasis in Phase II will be placed on accelerating the progress of:

Component 2: Synthesis of new and existing geological and geophysical data needed for the evaluation of earthquake hazards and research and ground motion and loss-estimation models.

Component 5: Fostering the implementation process by meeting user needs GOALS OF PHASE II

The overall goal of research and implementation tasks in Utah in Phase II is shown schematically in Figure 2. This goal, identified by the participants of the July 1986 workshop is to:

Assist user groups in Utah in devising and implementing a wide range of lossreduction measures in communities located adjacent to the Wasatch fault zone BEFORE the anticipated damaging earthquake occurs. 


\section{REGIONAL EARTHQUAKE HAZARDS ASSESSMENTS WASATCH FRONT, UTAH}

STATUS IN 1986

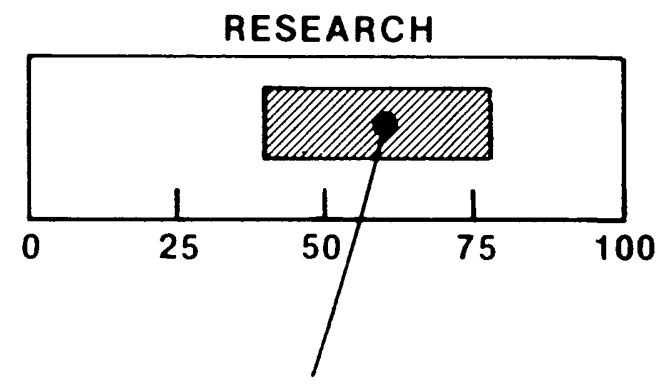

TRANSLATION FOR USE

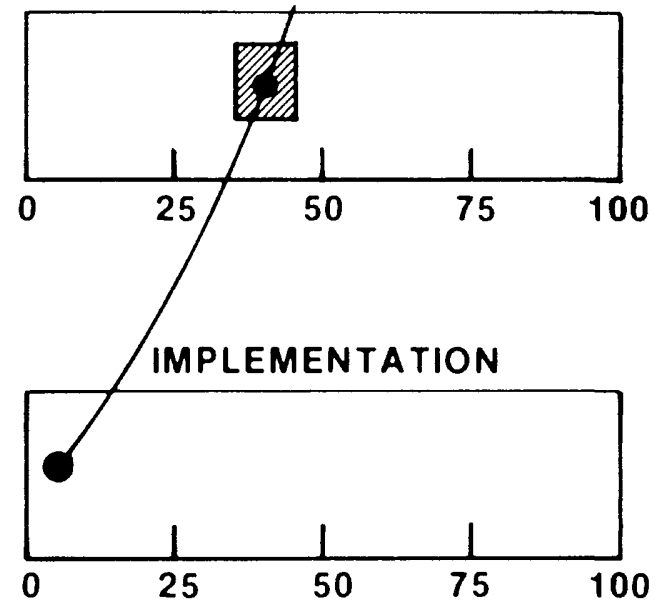

GOALS FOR 1990

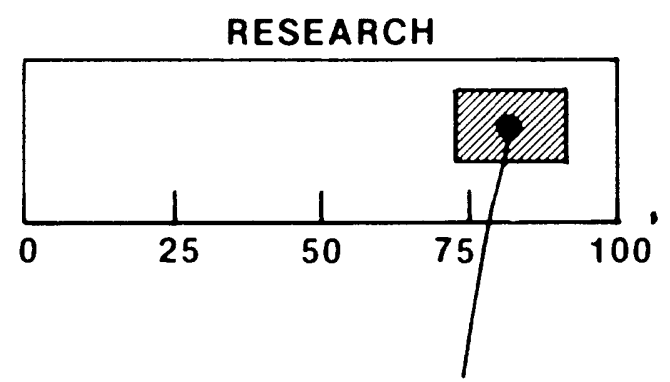

TRANSLATION FOR USE

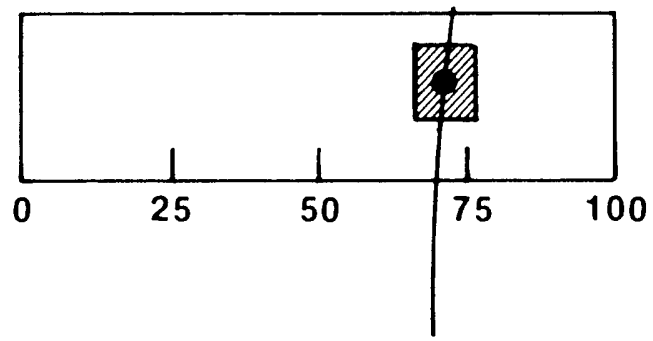

IMPLEMENTATION

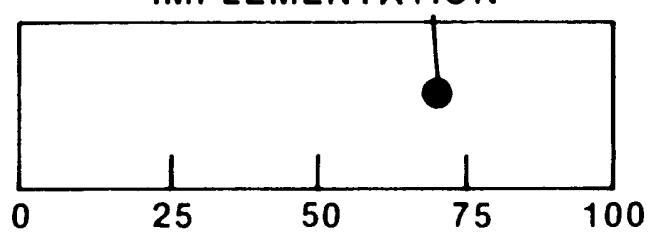

Note: Shaded box depicts range of opinions on percentage completed

Figure 1.--Schematic illustration showing the status of research and implementation in 1986 along the Wasatch front, Utah, after the completion of a 3-year concentrated effort (Phase I). The projected goals for 1990 are shown on the right of the graph. 


\section{Loss Reduction Strategies}

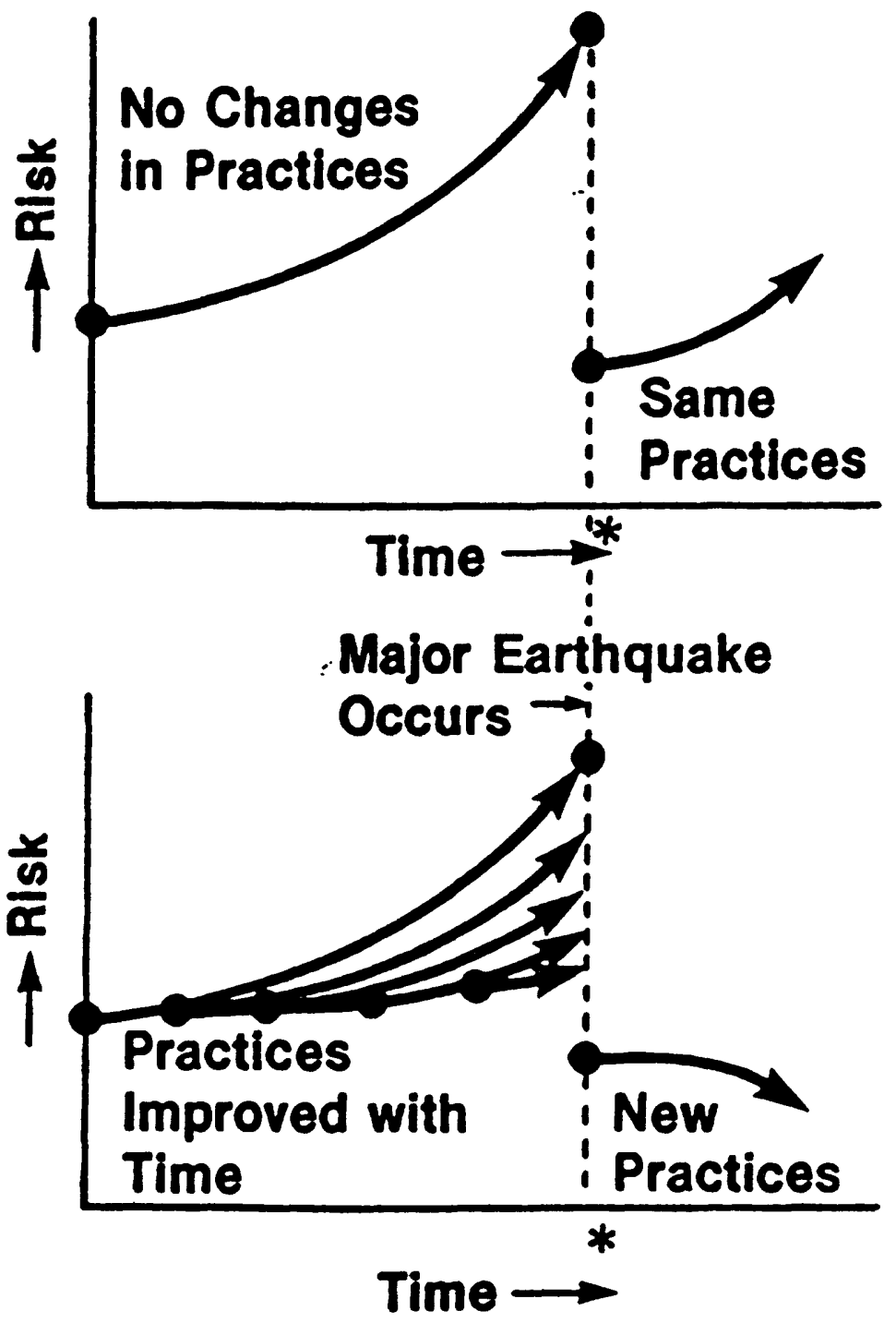

Figure 2.--Schematic illustration of the critical issue in the implementation process--"Will significant implementation of 1 oss reduction measures take place without a major earthquake?" 
Because we do not know when or where the damaging earthquake will occur, we must act as if its occurrence is imminent and that it will be a direct hit on any one of the communities along the Wasatch fault zone.

OBJECTIVES AND TASKS OF PHASE II

The principal objectives and tasks of the research and implementation activities to be carried out in Phase II are described below. In addition, the group(s) who will take the lead in accomplishing certain tasks are identified:

\section{SNYTHESIS AND TRANSLATION STANDARDS}

Objective 1: Provide to user groups the basis for implementation by synthesizing current scientific knowledge on all earthquake hazards as sociated with the Wasatch fault zone and other related fault zones in the urban areas along the Wasatch Front and set the standards for translation process.

Task 1: Synthesize current scientific information and data produced by Federal agencies in a set of maps, publications, and reports.

Lead : USGS

Task 2: Synthesize current scientific information and data produced by state agencies and others in a set of maps, publications, and reports.

Lead: UGMS

Task 3: Assess the coverage of scientific information available for the Wasatch Front and determine what, if any, gaps exists in the data coverage. Continue research on earthquake hazards assessment to ensure that all hazards are addressed and update existing information.

Lead: USGS, UGMS, University of Utah, Utah State Unviersity, Brigham Young University, J. Keaton, County Geologists.

Objective 2: Institutionalize the implementation process in Ut ah by establishing the procedure that makes scientific and translated information available for earthquake hazard evaluation to user groups and the public.

Task 1: Establish the UGMS as the "permanent memory" and secure it as Utah's official information source of earthquake hazard data as well as hazard ass es sment.

Lead: UGMS, CEM, universities

Task 2: Publish Professional Paper documenting the results of Phase I (part A) and Phase II (part B).

Lead: USGS

Task 3: Publish a folio of translated earthquake hazards maps and reports that are the official state maps for use by planners and others.

Lead: UGMS, County Geologists (through Utah Automated Geographic Reference (UAGR)). 
Task 4: Promote the need and establish a permanent base of funding for the

County Geologist Program in Jtah.

Lead: UGMS, CEM, USGS, FEMA, universities •

TRANSLATION, DISSEMINATION, AND MITIGATION

Objective 1: Provide translated earthquake hazard information to user groups that can get loss reduction measures adopted.

Task 1: Translate scientific data into products that address location, recurrence, and consequences of the earthquake hazards in a specific, accurate, consistent, and clear manner.

Lead: UGMS, USGS, County Geologists, CEM, Utah State University, Brigham Young University, J. Keaton

Task 2: Update loss estimates for the Wasatch Front area as inventories and ground shaking information are revised and made available.

Lead: USGS, UGMS

Task 3: Develop an ef fective process where translated earthquake information can readily be accessed by user groups and easily updated.

Lead: USGS, UGMS, IJAGR

Objective 2: Provide training and continuing education for professionals in Utah to improve their skills on translation and dissemination techniques.

Task 1: Assist UGMS geologists and the County Geologists in mastering translation requirements of the planning community and ef fective dissemination techniques.

Lead: USGS, Utah State University, D. Mileti (Colorado State University)

Task 2: Provide CEM technical support for their translation and dissemination effort.

Le ad: UGMS, County Geologists, USGS

Task 3: Provide opportunities to familiarize the planning community along the Wasatch Front with current earthquake hazards information.

Lead: County Geologists, Utah State University, CEM, UGMS

Task 4: Provide training and continuing education for professionals in Utah to improve their understanding of migitation techniques by assisting CEM, the County Geologists, and other key people in mastering the FEMA Earthquake Hazards Reduction Series to the point that the relevant information can be transferred to use rs at the local level. 
Lead: FEMA, USGS

Objective 3: Institutionalize a process that promotes mitigation measures which will lead to the adoption of seismic safety policies through legislation and ordinances that improves design, construction, and land-use practices.

Task 1: Update inventories of critical facilities and other high-risk structures along the Wasatch Front that are vulnerable to earthquake hazards for risk assessment. Have the information easily accessible to user groups.

Lead: CEM, FEMA, UAGR

Task 2: Conduct a feasibility study to determine how to integrate and use the earth sciences, planning, architectural, and engineering communities to upgrade the earthquake-resistant design provisions of the Uniform Building Code in Utah.

Lead: FEMA, CEM, Reaveley, UAGR, Ward, Barnes, BSSC, ICBO, ATC

Task 3: Cultivate one or more "Champions" in State government and the legislature to promote implementation of loss reduction measures.

Lead: USGS, CEM, County Geologists

\section{PREPAREDNESS EDUCATION FOR PUBLIC AWARENESS}

Objective 1: Provide clear, accurate, and credible information to the general public and State agencies to increase their awareness of earthquake hazards and mitigation measures that can reduce losses in Utah.

Lead: CEM, FEMA (UGMS for technical support)

Objective 2: Provide specific information to schools, churches, and ot her specific target groups to develop local support and establish a network that will be invaluable during a hazard emergency.

Lead : CEM, FEMA 


\section{UNIVERSITY OF WASHINGTON}

SEATTLE, WASHINGTON 98195

Graduate School of Public Affairs, DP-30

August 11, 1986

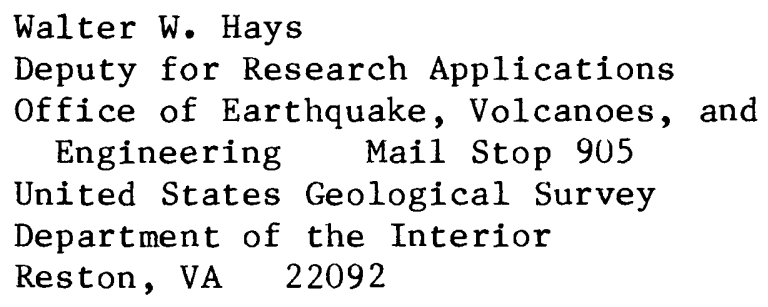

Dear Wa1t:

I am writing to provide a few observations about the Utah wrap-up and to raise some organizational issues for the Puget Sound effort. Needless to say, my attendance at the Utah session was important for stimulating thought about what follows.

By mid-September, I will be sending the final version, or close to it, of the report of the Washington State Seismic Safety Council. (We now have a final draft and are waiting for state agency comments.) I have asked Dick Buck to schedule some time as part of the October 1-2 planning meeting for Linda Noson and me to give an overview of the report and its implications for the next steps regarding policy development in the state.

First, a few impressions about the Utah session. I was impressed by a number of things that came together: (1) good press coverage; (2) reasonably strong advocacy for earthquake risk reduction within the state - particularly the role of UGMS; (3) the quality of the information base about potential risks and the technology for displaying it (e.g., Bob Alexander's work); and (4) a sense of momemtum, despite the recent legacy of inaction at the state level, which could be capitalized upon. At the same time, I was a bit surprised that more of the policy and implementation issues had not been thought through at the state and local level (e.g., the procedures for revising codes/zoning designations; the status of liability within the state, alternative financing mechanisms, costs of retrofits). Presumably that will come through the type of commitments you sought from agencies at the end of the sessions. Most importantly, it appears over the three years you made considerable headway in shifting from a primarily federally dominated effort (in terms of expertise and leadership) to more of a state driven effort. 
With respect to similar efforts in Washington state, I must admit considerable concern about the potential for fostering the type of state-level advocacy that is necessary for long run success in translating USGS research activities into effective state and local actions. The legacy in this state (detailed more fully in our report) is one of a series of ad hoc efforts - largely driven by interested individuals outside of state government - without strong

advocacy within state government agencies. Moreover, when federal funding has been made available to help "induce" state activity (e.g., FEMA funding of the so-called Puget Sound Earthquake Preparedness Effort), the state has largely dropped the ba11.

This may not strike you as being all that different than the situation going into Utah where the interim result seems to be the emergence of a strong state partner in UGMS. My sense, based upon conversations with those that have been on various sides of efforts to launch seismic safety efforts in our state and our own recent Council, is that the situation is different. The Division of Emergency Management is not likely to evolve as the lead advocate, as indicated by their 1imited capacity to deliver with the FEMA funding or to support our Council effort. The Geologist's Office may be a more compatible lead partner for you, but their function in state government restricts them from the necessary front-end policy work and advocacy. (Indeed, I would argue this is the limitation that UGMS ran into in Utah but was able to overcome in part because of the Director's political sensitivities and skills.) Our Seismic Safety Council is due to expire the end of the federal fiscal year. Even if continued, our progress is stymied by the lack of staff support for conducting or commissioning the type of research about costs, financing, loss potential, and so forth that is necessary for designing detailed policies or programs.

My suggestion is not to wait to see if a state leader emerges as was apparent1y done in Utah. Rather, I argue it is best to create the desired base by creating a state-based information and policy center for seismic safety. The key to this center is a strong individual with appropriate ties to state agencies. I am confident that the best individual is Linda Noson (who carries the title of "state seismologist" but who in reality is partially funded through the University of Washington without state funding for the title she carries). The appropriate organizational structure would be something like a USGS-funded University of Washington Seimsmological Information, Education, and Policy Center with provisions for state agency participation. Such an arrangement would provide a person with a demonstrated track record in this state and an organization that has both credibility among state agencies and sufficient freedom to begin to influence state and local policy.

The center, in conjunction with the Division of Earth Resources and Geology of Department of Natural Resources (Ray Lasmanis), would be essentially be responsible for the state-end of the partnership. This could include on-going educational and informational activities (response to press and individual inquiries, structured education programs), coordination of data sources and information, newsletter among particpants in the Puget Sound effort, and organizing seminars and the annual workshop. 
The implementation aspects of the USGS program could be promoted through the envisioned center, beginning early on, by establishing a "policy forum" in which various people are brought in to address liability, financing, and other issues. This could be linked to state policy development by creating an advisory board to the center that in effect plays the same role of the current Washington Seismic Safety Council. The difference from the current situation is that the newly created center would be positioned to provide a stronger staff and dissemination function than is presently the case.

Such a center need not require a large staff, since it is primarily coordinating other activities. It would take a director (Linda Noson) and perhaps two or three staff people plus appropriate support staff and operations funding. The "policy forum" to work well would require some funding for individual experts to write commissioned papers on key policy issues.

Let me close by indicating that this letter is written in an effort to offer constructive ideas about fostering state and local action in Washington state. The ideas are stimulated by my recent experience with the Seismic Safety Council, but also reflect the research $I$ have undertaken in studying federal-level (primarily FEMA) efforts to stimulate hazards reduction programs. Part of that research, noted in the enclosed flyer, has focused on the type of issues you have faced in making state and federal partnerships evolve over time so that states (and localities) become active in earthquake hazards reduction. Needless to say, these are my own views and do not necessarily reflect those of other members of the Washington State Seismic Safety Council.

I look forward to working with you and others in developing the USGS effort in the Puget Sound Area. Thank you again for inviting me to attend the Ut ah workshop.

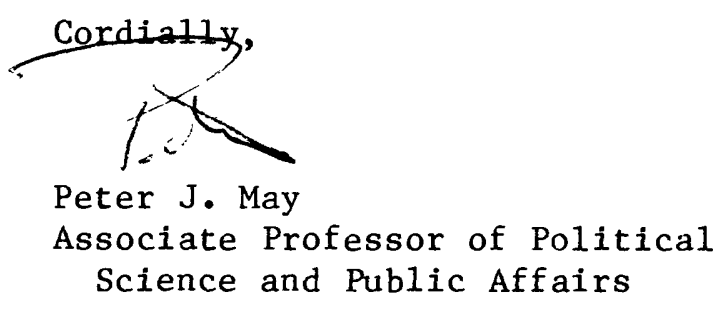

enc1.

cc: Dick Buck, FEMA Region X 
Statement prepared for presentation to House Subcommittee on Science, Research and Technology: March 10, 1987.

\author{
by \\ Don R. Mabey, Deputy Director \\ Utah Geological and Mineral Survey
}

Utah has not experienced a highly destructive earthquake in a major population center since the first permanent settlements were established 140 years ago. However, every earth scientist that I know, who has examined the geologic record, agrees that on the average of once every few hundred years major earthquakes have occurred in the area where 90 percent of Utah's population resides, and they agree that Utah should be prepared for a major earthquake to occur at any time.

It was G.K. Gilbert, one of the U.S. Geological Survey's and this Nation's most famous geologists, who first warned of the earthquake hazard to Salt Lake City. In 1883, four years after the USGS was organized, Gilbert wrote the first paper by a USGS scientist on earthquakes and it was published on the front page of the Salt Lake Daily Tribume. In this paper, he documented the geologic evidence that Salt Iake City was in an active earthquake zone and pointed out the vulnerability of many buildings in Salt lake City to earthquakes. He concluded by stating:

It is useless to ask when this disaster will occur. our occupation of the country has been too brief for us to learn how fast the Wasatch grows: and, indeed, it is only by such disasters that we can learn. By the time experience has taught us this, Salt Lake City will have been shaken down and its surviving citizens will have sorrowfully rebuilt it of wood: to use a homely figure, the horse will have escaped, and the barndoor, all too late, will have been closed behind him.

The thrust of our earthquake program in Utah is to avoid what Gilbert predicted. We want to take actions now, before the first highly destructive earthquake hits the Wasatch Front population center; actions that will minimize the loss of life, destruction of property and the disruption to the economy of Utah and the Intermountain Region. Because our knowledge of the earthquake hazard is based on scientific research rather than experience, the earthquake research conducted by or supported by the USGS is essential to this effort.

Prior to 1983, research, largely supported by the USGS and NSF, had established that a serious earthquake hazard existed in the wasatch Front area and provided general indications of the major effects to be expected when an earthquake cocurs. The University of Utah Seismograph Stations - with substantial funding support from the National Earthquake Hazards Reduction Program - was operating a network of seismograph stations. In 1981, the Utah 
Seismic Safety Advisory council, funded by the State of Utah with technical assistance from the USGS, had published a list of recommended seismic safety actions but the recommendations were generally being ignored. There was no state or local govermment agencies actively promoting earthquake hazard recuction. This was the status when the USGS approached the Utah Geological and Mineral Survey with a proposal to develop a cooperative program of Earthquake Hazards Reduction for the Wasatch Front area of Utah.

In a series of meetings between the two organizations the objectives for a three year program were defined. Five elements were included: (1) Hazard Definition, (2) Strong Motion Modeling, (3) Lost Estimation Modeling, (4) Information Systems, (5) Implementation. This last element, implementation, was to receive particular emphasis. We have made significant progress in all elements. In the hazard definition element a particular important development is the improved understanding of the recurrence rate of major earthquakes on the Wasatch fault. In this element state geologists have worked with and been trained by USGS experts working in Utah. As a result of this training Utah now has a staff much better trained to conduct earthquake investigations. As part of the strong motion element a badly needed network of strong motion instruments has been installed.

In the information area we have dramatically improved communication between groups concerned with earthquake hazard recuction in the region. A quarterly earthquake publication, The Wasatch Forum, was established. It is printed and distributed by the state but has been edited by a USGS information specialist. Beginning this summer one of our staff will become editor. We have conducted several workshops - some general and others targeted at specific groups or organizations. We are translating the results of the scientific research into a series of interpreted maps and reports that can be used directly by planners, engineers and others. A computer based system developed by the USGS for managing and applying earthquake and other geologic hazard information has been transferred to the state computer system.

The earthquake hazard has received substantial publicity in newspaper reports and editorials and in radio and television broadcasts. A particularly important hour-long documentary on the Wasatch Front earthquake hazard entitled "When - Not If" was recently broadcast twice in prime time by one of Salt Lake City's major television stations. Public awareness of the hazard is high.

We have developed effective coordination between the Utah Geological and Mineral Survey and USGS hazard investigation programs on one hand and the State Division of Comprehensive Emergency Management, who manages the FEMA supported earthquake response and education programs, on the other.

We are particularly pleased with progress related to implementation. In Utah most responsibilities for actions involving earthquake hazard reduction are at the city and county levels. We concluded that if the local govermments had a hazards geologist on their staffs to work with county and city planning and engineering departments and advise other officials, actions to promote seismic safety would be more likely. We proposed a program with the USGS providing temporary funding for the salaries of hazards geologists for the Wasatch Front counties, the Utah Geological and Mineral Survey organizing and supervising the program and the counties providing administrative support. The USGS and the counties agreed and the program was established. The four most populous counties are employing three geologists with the two smallest of these four counties sharing one geologist. The program is a major success. The 
local govermments are now using geology in the development and review of projects much more than before. And most important, even though all four counties have severe budget problems, they have tentatively agreed to continue the employment of the geologists after the Federal funding is terminated next year.

Another important need was to establish an Earthquake Information office at the State level to provide a contimuing source of earthquake hazard information and advocate seismic safety measures. Two weeks ago, despite budget problems that required reduction of appropriations to most state agencies to 91 percent of current year's level, the Utah State Legislature approved new state funding for an Earthquake Hazard Information officer - another major advance.

Since the start of the program seven Wasatch Front cities have adopted geologic hazard ordinances with earthquake safety elements. Included are three of the state's four largest cities - Salt Lake City, Provo and ogden. Two more cities and three of the four targeted counties are currently developing similar ordinances.

overall, the program has been a major success but some phases have not worked as well as others. The procedures for awarding grants does not always produce the most needed research, and we have not been completely successful in coordinating individual projects funded under the grants program with other activities in the Wasatch Front program. Although coordination with USGS projects has been generally good, the state of Utah has not been able to work as well with the lost Estimate Studies projects as we had hoped.

The progress made in three years by the Wasatch Front Earthquake Hazard Reduction Frogram is impressive. We have obtained a significantly improved understanding of the earthquake hazard. We have greatly improved public awareness of earthquake hazards. State technical personnel are better trained. We have developed systems for managing and communicating hazard information. We have developed, through the county Hazards Geologist Program, a system for utilizing the information at the local level, which we believe will contimue. And most importantly, we have obtained an impressive commitment from all levels of govermment to actions to reduce the earthquake hazard.

I can assure the committee that the efforts of the U.S. Geological Survey Earthquake Hazard Reduction Program in the Wasatch Front area of Utah are accomplishing the defined objectives. It is an outstanding example of a Federal effort aiding a state to accomplish a program that the state had neither the funding or technical resources to do alone. Similar programs can be expected to work in other areas, and I recommend that they be supported. I also want to stress that the success of the Wasatch Front Program was achieved because there was a strong foundation of scientific research on earthquake hazards built by years of work supported by the National Earthquake Hazards Recuction Program. Any substantial reductions in this research effort will undermine this foundation and in the long run prove to be unwise. 


\section{TECTONIC FRAMEWORK AND EARTHQUAKE POTENTIAL \\ OF THE WASATCH FRONT AREA AND OTHER PARTS OF UTAH}

By

Michael Machette, U.S. Geological Survey

William Lund, Utah Geological and Mineral Survey

Walter Arabasz, University of Utah

OBJECTIVES OF THE RESEARCH ACTIVITIES DURING THE PAST THREE YEARS

Objectives of this part of the NEHRP Program on "Regional Earthquake Hazards Assessments--Wasatch Front, Utah," were outlined in USGS Open-File Report 84763 (p. 22-44). Studies undertaken along these objectives fall into two broad fields: Geologic Framework Studies and Seismological/Geophysical Studies. Generally, the objectives are to collect and synthesize basic geologic and geophysical data required for evaluation of earthquake hazards and to conduct additional research needed to achieve the goals of the program element.

Some specific research activities were outlined at the August, 1984 planning session for USGS and UGMS scientists. In addition, pertinent research was undertaken by the academic and private sector under the auspices of the USGS's grants and contracts program. However, the earthquake near Borah Peak, Idaho, on 0ctober 28,1983 , caused significant diversion of scientific effort from the Wasatch Front work: studies of the behavior and setting of this strong, recent earthquake in the Intermountain Seismic Belt clearly have been of enormous value to our understanding large-magnitude earthquakes that may occur in the Wasatch Front area. For this reason, several studies of the 1983 earthquake have been included in the following list of research objectives and principal investigators.

Geologic Framework Studies

* Quaternary geology of the Wasatch Front; Honeyville to Fayette, Utah (Machette, USGS)

* Statistical analysis of segmentation of the Wasatch fault zone (Wheeler, USGS)

* Tectonic geomorphology of the Wasatch Front (Mayer, Miami Univ., Ohio)

* Evaluation of paleoseismicity on the Salt Lake City segment of the Wasatch fault zone (Lund, UGMS)

* Structure of the Salt Lake City segment of the Wasatch fault zone (Bruhn, Univ. of Utah)

* Evaluation of paleoseismicity and earthquake hazards of the West valley fault zone, Salt Lake urban area (Keaton, Dames and Moore)

* Neotectonics of the Hansel Valley-Pocatello Valley corridor, northern Utah and southern Idaho (McCalpin, Utah State Univ.)

* Late Quaternary tectonics of Cache Valley, Utah (McCalpin, Utah State Univ.)

* Late Quaternary history of the James Peak fault, Utah (Ne1son, USGS and USBR)

* Neotectonic framework of the central Sevier Valley area, Utah, and its relationship to seismicity (Anderson, USGS)

* Surface faulting associated with the 1983 Borah Peak, Idaho, earthquake (Crone, USGS) 
Seismological/Geophysical Studies

* Review and evaluation of crustal models, Basin and Range province (Pakiser, USGS)

* Geophysics of eastern Great Basin transition zone (Diment, USGS)

* Regional geophysics and tectonic framework of the Wasatch Front region--Constraints on stress state (Zoback, USGS)

* Interpretation of subsurface and geophysical data, Utah Valley to ogden (Mabey, UGMS)

* Subsurface geometry of late Quaternary faults, Wasatch Front (Crone, USGS)

* Tectonic deformation, Wasatch Front region (Wood, USGS and Boise State Univ.)

* Strain measurements in the Wasatch Front area (Savage, USGS)

* Seismological, geophysical, and geodetic studies of the Borah Peak earthquake (many investigators from USGS and Univ. Utah)

* Regional seismic monitoring (Univ. Utah)

* Analysis of regional seismic network data (Univ. Utah)

* Identification of source zone characteristics and earthquake potential estimates (Univ. Utah)

ASSESSMENT OF THE EXTENT TO WHICH OBJECT IVES HAVE BEEN MET

Following a general discussion, our assessments of the extent to which the objectives of this research program have been met are grouped as follows: Geologic Framework Studies (al1 investigators) and Seismologica1/Geophysical Studies by the USGS and UGMS and by the University of Utah. This division parallels the objectives outlined above.

At the August 1984 USGS/UGMS workshop on earthquake hazards and risk in Utah, it appeared that despite abundant previous work on various aspects of the seismotectonics of the Utah region, researchers had strong convictions about how much of importance was not known about fault segments, recency of movement, earthquake behavior, and fault mechanics in the region. Such fundamental studies would have to be pursued on a long-term basis. Clearly, many critical problems weren't going to be solved in the remaining 2 years of the "Wasatch Front initiative"--especially given the time lags inherent to programmatic scheduling and budget limitations. The implicit strategy seemed to call for appropriate response to short-term priorities for implementationoriented products, but persistent and continued work on key problems that researchers had defined. In the areas of seismology and geophysics especially, this seems to be precisely what has happened in the Utah region.

\section{Geologic Framework Studies}

One of the critical products for the implementation phase of this program is the maps that show surficial geology along the Wasatch Front. These maps, six in al1, are being compiled by Machette, Personius, Nelson, and Scott of the USGS. The mapping has been completed and Scott's map of the Salt Lake City area has been released. McCalpin started a similar mapping project in the Cache Valley and he is cooperating with the USGS to insure a compatible product. His mapping should be completed by the end of FY87. 
Fundamental studies of slip rates on and segmentation of the Wasatch fault zone published by Schwartz and Coppersmith (1984) are being expanded through the aforementioned mapping efforts, and by site-specific studies conducted by the UGMS and USGS. The results of statistical analyses of fault segmentation by Wheeler and by tectonic geomorphology by Mayer and Maclean generally support the ten fault segments currently proposed for the Wasatch fault zone. Investigation of one new trench has been completed by the UGMS and USGS (Lund and Schwartz) and three more sites are planned for excavation in FY86. Completion of these studies will provide at least one excavation site on the eight fault segments suspected of having Holocene displacement.

Studies of other faults in the region, such as in the Hansel valley by McCalpin and in the southern Cache Valley and Strawberry Valley by Nelson and others, have contributed greatly to our understanding of fault mechanics and timing in the eastern Basin and Range province and the western Rocky Mountains. Recent stratigraphic, paleontologic, and radiometric studies of lake sediments in the Bonneville Basin by Scott and others, Currey and Oviatt, and McCalpin have provided a modern, detailed framework for correlation of surficial deposits along the wasatch Front.

Studies of the surface ruptures as sociated with the 7.3 Borah Peak earthquake have advanced our understanding of fault segments, rupture propagation, and the geometric patterns and of fet amounts associated with large-magnitude earthquakes in the Intermountain Seismic Belt. Drawing from these studies, Bruhn has suggested a scenario for rupture propagation during narmal faulting on the Salt Lake City segment of the Wasatch fault zone.

Perhaps the most important objectives that remain to be accomplished are (1) a thorough understanding of the most recent movement along all segments of the fault zone, (2) better definition of the ends of segments, and (3) understanding how and what geologic structures might control segment ends. However, planned and continued work toward these objectives should provide a satisfactory data base for future hazards analysis work.

Seismological/Geophysical Studies by the USGS/UGMS

In assessing the USGS/UGMS accomplishments, apparent changes in execution of the initial program plan are reflected by (1) the absence of reports by some of the early-identified project leaders and (2) the authorship of relevant reports by some other authors. Also, the occurrence of the Borah Peak earthquake shortly after the official start of the program (FY84; Oct. 1, 1984 ) caused changes and dilutions of time on project assignments.

Objectives dealing with an evaluation of crustal models for the Basin and Range province and the geophysics of the eastern Great Basin transition zone do not appear to have been pursued--at least not as originally planned. However, Zoback (USGS) has studied various aspects of the geophysics and tectonic framework of the Utah region. Major efforts by Mabey and by Case indicate significant completion of the UGMS objective of interpreting subsurface and geophysical data for filled valleys along the Wasatch Front. Investigation by the USGS of subsurface fault geometry along the Wasatch Front has involved (1) Crone and Harding's acquisition and interpretation of MINIESOSIE high-resolution seismic reflection data for investigation of nearsurface faulting and Zoback's interpretation of a 30-km-long seismic 
reflection profile across the Wasatch fault zone near Nephi. Finally, although Wood started monitoring of tectonic deformation along the Wasatch Front this aspect of the program has not been continued.

Most of the short-term geophysics-related objectives originally outlined for the USGS/UGMS appear to have been met--recognizing that final reporting is still underway.

Seismological/Geophysical Studies by the University of Utah

Seismological research by the University of Utah continues to be intrinsically long-term in nature. Short-term research objectives are proposed for competitive funding on an annual basis under the USGS's external research program. The basic objectives of regional seismic monitoring and interpretation of seismic network data are being met on an ongoing basis. A synopsis of successes and some persistent problems in meeting specific research objectives is given in item 3 ("Significant Accomplishments").

SIGN IFICANT ACCOMPL ISHMENTS, OCTOBER 1983 TO PRESENT

This summary of significant accomplishments is necessarily subjective, and the bibliographic citations are not exhaustive. The list follows that outlined in items 1 and 2. Most USGS Projects and outside contracts file Semi-annual Technical Reports, which have been compiled in USGS Open-File Reports (OFR) $84-268,85-22,85-464$, and $86-31$ for FY84 and FY85 (the first 2 years of this program).

Geologic Framework Studies (al1 personnel)

* Quaternary geology of the Wasatch Front; Honeyville to Fayette, Utah: of the six maps being compiled, two are in final form. Personius (1986) has completed a map of the Brigham City segment at a scale of $1: 50,000$ and Scott and Shroba (1985) published a preliminary version of the Salt Lake City map at 1:24,000 scale. Information concerning large-scale changes in slip rate on the Wasatch fault zone was summarized by Machette (1984) and Machette and others (1986).

* Studies of segmentation of the Wasatch fault zone: Three independent approaches to this problem have yielded compatible results. Wheeler (1986) recognizes four persistent segment boundaries for the Quaternary, whereas Maclean (1985), Mayer and Maclean (1986), and Machet te and others (1986) recognize as many as ten late Quaternary fault segments, eight of which have demonstrable Holocene movement.

* Paleoseismicity on the Salt Lake City segment of the Wasatch fault zone: Trenching at Dry Creek (the only remaining site suitable on the segment) has yielded new information on the two most recent fault events (Lund and Schwartz, 1986). When dating is completed, it will be possible to determine a slip rate and recurrence interval for this segment of the fault zone.

* Structure of the Salt Lake City segment of the Wasatch fault zone: As a direct result of observations made from the Borah Peak and Hebgen Lake earthquakes, Bruhn and others (1986) developed two scenarios for rupture propagation during a large-magnitude earthquake on this fault segment. If shown valid, this type of analysis would allow others to make more accurate predictions of earthquake damage. 
* The West Valley fault zone, Salt Lake urban area: Keaton and others'

(1986) investigation of two previously unstudied faults shows a history of multiple offsets not unlike the Wasatch fault zone. Slip rate versus time shows marked increase in faulting after withdrawal of Lake Bonneville.

* Neotectonics of the Hansel Valley-Pocatello Valley corridor, northern Utah and southern Idaho: McCalpin and others described evidence of prehistoric ruptures on two faults that have had recent activity (1934 and 1960). Faults in the Hansel Valley show 4-5 events in the past 65$140 \mathrm{ka}$, and major of fset seems to be associated with deep lake cycles in Bonneville Basin. Their thermoluminescence dating study shows potential for dating faulted deposits of less than 200,000 years age.

* Late Quaternary tectonic history of the James Peak and Strawberry faults, Utah: Although investigated as part of a Bureau of Reclamation program on dam safety, these studies have added to our appreciation of tectonics in the back valleys of the Wasatch Front. Nelson and Sullivan (1986) and Nelson and VanArsdale (1986) have shown that these faults have substantially lower slip rates and longer recurrence intervals than the Wasatch fault zone.

* Neotectonic framework of the central Sevier Valley area, Utah, and its relationship to seismicity: Anderson and Barnhard (1984 and 1986) have used paleoslip indicators to decipher the history and direction of slip on late Tertiary faults. These studies show that the area has concentrated microseismicity, suggestive of strike-slip faulting, at complex structural junctures. Although the results are not applicable to the Wasatch Front, the area's seismicity may be related to thin-skin detachments and the recently mapped strike-slip faults probably are not capable of generating large-magnitude earthquakes.

* Geologic studies of the 1983 Borah Peak, Idaho, earthquake: In addition to a multitude of significant papers in the Borah Peak volumes (USGS OFR 85290), there have been several other papers that contribute to this program. Scott and others (1985) describe the geologic and tectonic setting for the earthquake on the basis of their regional study of the Snake River Plain and adjacent areas. Crone and Machette (1984) summarized the initial results of the USGS's investigation of surface ruptures associated with the earthquake.

\section{Seismological/Geophysical Studies (USGS/UGMS)}

* Regional geophysics and tectonic framework of the Wasatch Front region: Constraints on stress state (Zoback, 1984); compilation of Utah gravity data, investigation of crust-mantle structure beneath the Western U.S., and analysis of seismic reflection and gravity data from the Sevier Desert basin in central Utah (summarized in OFR's).

* Interpretation of subsurface and geophysical data for filled valleys along the Wasatch Front: Compilation of significant drill-hole data (Case, 1985); synthesis of gravity, magnetic, and seismic reflection data for investigation of basin-fill thickness and blocks of contrasting bedrock 1 it thology (Mabey, 1986).

* Subsurface geometry of late Quaternary faults (Crone and Harding, 1984; Zoback, 1986); also see OFR summaries by Crone and Harding).

* Monitoring tectonic deformation along the Wasatch Front (Wood, 1984).

* Strain measurement in the Wasatch Front area (Savage and others, 1985). 
* Seismological, geophysical, and geodetic studies of the Borah Peak, Idaho, earthquake: Many reports (not all cited in the Appendix) printed in OFR 85-290 (the Borah Peak volume A); some are in press in the Bulletin of the Seismological Society of America. Includes studies of seismicity (J.W. Dewey), source characteristics (J. Boatwright and G.L. Choy), intensity distribution (C.W. Stover), and geodesy (R.S. Stein and S.E. Barrientos).

\section{Seismological/Geophysical Studies (University of Utah)}

* Seismological studies of the Borah Peak, Idaho, earthquake (Doser, 1985; Doser and Smith, 1985; Richins and others, 1985; Smith and others, 1985; Zollweg and Richins, 1985).

* Correlation of seismicity with geologic structure of the Wasatch Front area (Arabasz, 1984; Arabasz and Julander, 1986; Smith and Bruhn, 1984; also see reports of the University of Utah Seismograph Station).

* Geodetically, geologically, and seismologically determined strain rates (Smith and others, 1984; Snay and others, 1984; Eddington and others, 1985).

* Wave-form analysis: Cross-correlation studies using digital data from the Univ. of Utah seismic network for high-precision resolution of discrete loci of seismic slip and for waveform analysis of sequences of preshocks, mainshocks, and aftershocks (Pechmann and Thorbjarnardottir, 1984).

* Pore fluid, seismogenic characteristics of faulted rock at depth, and longterm uplift rates on the Wasatch fault zone (Parry and Bruhn, 1986).

* Network seismology: Upgrade, calibrate, and modify the Univ. of Utah seismic network, including development of portable telemetry stations for special studies, and development of four-component, higher-dynamic-range stations for source studies. (Summaries relating to this seismic network appear regularly in OFR's, and an expanded description of accomplishments ap pears in the Proceeding of the 0ct. 1985 Symposium and Workshop on Regional Seismographic Networks, convened by the National Research Council.)

* Other network-related studies: Results and citations relating to other research accomplishments since 0ct. 1983 are summarized in OFR's. Two notable projects involve studies of source properties of local earthquakes and investigations of crustal structure from network data.

\section{RECOMMENDATIONS FOR FURTHER RESEARCH}

Extensive group discussions were held at the 1984 USGS workshop on earthquake hazards and risk in Utah regarding recommendations for future seismological/geophysical research. The summary and recommendations made at that time are still relevant (USGS Open-File Report 84-763)--es pecially in view of the inherent long-term nature of such studies. These include specific recommendations for better documentation of fault history, es pecially the age of most recent movement on each fault segment, expanded geodetic studies, investigations of subsurface fault geometries throughout the seismogenic layer of the crust, and accelerated research in seismology.

Several specific recommendations for the next two years either were made or reiterated at the 1986 meeting in the panel discussion group. There seemed to be a consensus that there are four critical as pects of the work that apply to the next 2 years. These are broadly grouped as follows: (1) recognition of 
short-term users needs (i.e. is the data base adequate for synthesis and implementation?), (2) a strong need for synthesis of the existing (1986) geologic data, (3) many of the results have fundamental importance to the fields of geology, seismology, and geophysics, and (4) there is an element of urgency in the geologic studies because many of the important exposures are being concealed.

User needs

Three items of very high priority are needed by users (which includes other geologists).

* Assessment of earthquake potential including refinement of recurrence intervals, lapse times, and causal factors related to apparent changes in slip rate on the Wasatch fault zone. This assessment should include scenarios for moderate magnitude earthquakes (M 5.5-6.5) as well as large ones (M 7.5).

* Construct maps of surface faulting/zones of deformation for postulated earthquake events along the populated segments of the fault zone.

* Review the scientific assumptions for probabilistic estimates of ground shaking.

Synthesis of existing data Most of these items were judged to be of high priority to the program.

* Tie seismicity to geologic structures subsurface geology, geophysics, and bedrock geology.

* Review and refine the earthquake data base.

* Compile a modern (Quaternary) fault map for the state of Utah.

* Synthesize data and use multidisciplinary team to interpretate the geometry and lithology of the thick fault-bounded basins along the Wasatch Front.

* Compile a catalog and designate a repository (UGMS) for "gray literature" and other relatively obscure data sources (including early vintage terrestrial and aerial photographs).

\section{Urgent elements}

Because of the ephemeral nature of many exposures in the urban corridor, the collection of certain types data is judged to be urgent. The first three items seemed to be of very high priority, and the remaining two were of high priority.

* Potential trench sites on faults in the urbanized areas are disappearing rapidly. Special attention should be directed to trenching sites which may soon become inaccessible.

* More geologic data are urgently needed from some segments (specifically the Weber, Salt Lake City, and Provo).

* There should be more emphasis placed on a systematic excavation inspection program and its coverage should be expanded outside of the Salt Lake City metropolis. In addition, highest priority should be placed on the continuation, past FY 88, of the County Geologist Program, because these geologists provide a critical link between the scientific community and the user community. 
* Someone needs to make a systematic search for unrecognized faults in urban areas and beneath both Great Salt Lake and Utah Lake. A shallow sparker survey of the lakes could have a high payback.

* There should be an ef fort to collect earthquake precursor data (geodetic, gas emission, water level change, etc.).

Items of importance to science

Although these items may seem esoteric to the non-scientfic community, they were judged to be important to our general understanding of earthquake mechanics and ultimately to the assessment of the potential for large devastating earthquakes along the Wasatch Front. These items are generally viewed as longer-term research problems, but are of no less importance than the short-term needs.

* Acquire high-quality digital wave-form data.

* Develop a more complete stratigraphic model based on absolute age determinations.

* Study the structural character of fault segments and barriers to develop a framework for subsequent models of earthquake nucleation and rupture propagation.

* Find world-wide analogs to structural setting and style of the Wasatch fault zone.

* Maintain and expand our geodetic monitoring networks in the region. In addition to the general topics mentioned above, several items were consistently mentioned in the panel discussions that appear to deserve further attention.

\section{Geologic Framework Studies}

* As further-site specific investigations are conducted (mainly trenches), there should be a continued ef fort to refine fault zone segments, especially boundary conditions of and structural controls between segments.

* Evaluate the seismic history of various fault segments (probably the five between ogden and Santaquin) through as many seismic (and stratigraphic) cycles as possible. Length and amount of of $\mathrm{fset}$ need to be determined for paleoearthquakes along each fault segment to better define the maximum magnitude of potential earthquakes. Well-constrained values for elapsed time since the most recent event and recurrence interval between former events are required to make a probabilistic analysis of seismic hazard potential along the wasatch Front.

* Further investigations of the possible causal relation between deep-lake cycles and seismicity on the Wasatch fault zone. A thorough mechanical analysis of the possible effects of a deep lake should be performed, since basin-margin and intrabasin faults may respond differently to the same lithostatic and hydrostatic loads.

\section{Seismological/Geophysical Studies}

* There appears to be a clear need for a systematic review and refinement of the earthquake data base for the Utah region by the USGS, the University of Utah, and other involved parties. More formal coordination in assembling these data should have occurred in the past 2 years. Stateof-the-art probabilistic hazard computations clearly require significant preparatory work involving rigorous statistical analysis of earthquake 
catalog information. And it is essential that such efforts be carried out in an "open" forum.

* National review of regional seismographic networks makes it clear that networks such as that operated in the region by the University of Utah are woefully inadequate for critical modern studies because of their band-1imited, low-dynamic-range, seismographic characteristics. Early attention should be given to this problem.

\section{REFERENCES CITED}

Anderson, R.E., and Barnhard, T.P., 1984, Extensional and compressional paleostresses and their relationship to paleoseismicity and seismicity, central Sevier Valley, Utah: U.S. Geological Survey Open-File Report 84763, p. 515-548.

Anderson, R.E., and Barnhard, T.P., 1986, Neotectonic framework of the central Sevier Valley area, Jtah, and its relationship to seismicity: Title submitted for USGS Professional Paper; expanded abstract available.

Arabasz, W.J., 1984, Earthquake behavior in the Wasatch Front area: Association with geologic structure, space-time occurrence, and stress state: U.S. Geological Survey Open-File Report 84-763, p. 310-339.

1986, Observational seismology and earthquake hazards evaluation in the Wasatch Front area: Title submitted for USGS Professional Paper, expanded abstract available.

Arabasz, W.J., and Julander, D.R., 1986, Geometry of seismically active faults and crustal deformation within the Basin and Range-Colorado Plateau transition in Utah: Geological Society of America Special Paper 208 (in press).

Bruhn, R.L., Gibler, P.R., Houghton, W., and Parry, W.T., 1986, Structure of the Salt Lake segment, Wasatch normal fault zone: Implications for rupture propagation during normal faulting: Title submitted for USGS Professional Paper; expanded abstract available.

Case, W.F., 1985, Significant drill holes of the Wasatch Front valleys including Cache Valley and Tooele Valley: Utah Geological and Mineral Survey Open-File Report 82. (For summary, see USGS Open-File Report 86-31, p. 523.)

Crone, A.J., and Harding, S.T., 1984, Near-surface faulting associated with Holocene fault scarps, Wasatch fault zone, Utah--A preliminary report: U.S. Geological Survey Open-File Report 84-763, p. 241-268.

Crone, A.J., and Machette, M.N., 1984, Surface faulting accompanying the Borah peak earthquake, central Idaho: Geology, v. 12, no. 11, p. 664-667.

Currey, D.R., and Oviatt, C.G., 1986, Durations, average rates, and probable causes of Lake Bonneville expansions, stillstands, and contractions during the last deep-lake cycle, 32,000 to 10,000 years ago: Manuscript submitted for USGS Professional Paper.

Doser, D.I., 1985, Source parameters and faulting processes of the 1959 Hebgen Lake, Montana, earthquake sequence: Journal of Geophysical Research, v. 90, p. 4537-4555.

1985, The 1983 Borah Peak, Idaho and 1959 Hebgen Lake, Montana earthquakes: Models for normal fault earthquakes in the Intermountain seismic belt: U.S. Geological Survey Open-File Report 85-290, p. 368-384.

Doser, D.I., and Smith, R.B., 1985, Source parameters of the 28 October, 1983 Borah Peak, Idaho, earthquake from body-wave analysis: Bulletin of the Seismological Society of America, v. 75, p. 1041-1052. 
Eddington, P.K., Smith R.B., and Renggli, K., 1985, Kinematics of Basin-Range intraplate extension: Geological Society of London, Proceedings of Symposium on Continental Crustal Extension (in press).

Keaton, J.R., Currey, D.R., and 0lig, S.J., 1986, Paleoseismicity and earthquake hazards evaluation of the West Valley fault zone, Salt Lake urban area: Title submitted for USGS Professional Paper; expanded abstract available.

Lund, W.R., and Schwartz, D.P., 1986, Trenching along the Salt Lake segment of the Wasatch fault zone: Title submitted for USGS Professional Paper; expanded abstract available.

Mabey, D.R., 1986, Subsurface geology along the Wasatch Front: Title submitted for USGS Professional Paper.

Machette, M.N., 1984, Preliminary investigations of late Quaternary slip rates along the southern part of the Wasatch fault zone, central IJtah: USGS Open-File Report 84-763, p. 391-406.

Machette, M.N., Personius, S.F., Scott, W.E., and Nelson, A.R., 1986 , Quaternary geology along the Wasatch Front: Evidence for ten fault segments and large-scale changes in slip rate along the Wasatch fault zone: Title submitted for USGS Professional Paper; expanded abstract available.

Mayer, L., and Maclean, A.S., 1986, Tectonic geomorphology of the Wasatch Front, Utah, using morphologic discriminant analysis--preliminary implications for Quaternary segmentation of the Wasatch fault zone: Geological Society of America Abstracts with Programs, v. 18, no. 2, p. 155.

Maclean, A.S., 1985, Quaternary segmentation of the Wasatch fault zone, Utah, as studied by morphometric discriminant analysis: Oxford, Ohio, Miami University M.S. thesis, 200 p.

McCalpin, James, 1986, Thermoluminescence (TL) dating in seismic hazard evaluations--an example from the Bonneville Basin, Utah: Proceedings of the 22nd Symposium on Engineering Geology and Soils Engineering, Boise, Idaho, 1986, p. 156-176.

1986, Neotectonics of the Hansel Valley-Pocatello Valley corridor, northern Utah and southern Idaho: Title submitted for USGS Professional Paper; expanded abstract available.

Nelson, A.R., and Sullivan, J.T., 1986, Late Quaternary history of the James Peak fault, southernmost Cache Valley, north-central Utah: Title submitted for USGS Professional Paper; expanded abstract available.

Nelson, A.R., and VanArsdale, R. B., 1986, Recurrent late Quaternary movement on the Strawberry normal fault, Basin and Range-Colorado Plateau transition zone: Neotectonics, v. 1, no. 2, p. 7-37.

Parry, W.T., and Bruhn, R.L., 1986, Pore fluid and seismogenic characteristics of fault rock at depth on the Wasatch fault, Utah: Journal of Geophysical Research, v. 91, p. 730-744.

Pechmann, J.C., and Thorbjarnardottir, B., 1984, Investigations of a $\mathrm{M}_{\mathrm{L}} 4.3$ earthquake in the western Salt Lake Valley using digital seismic data: U.S. Geological Survey Open-File Report 84-763, p. 340-365.

Personius, S.F., 1986, Surficial geologic map of the Brigham City segment and part of the Collinston segment, Wasatch fault zone; Box Elder and Weber Counties, Utah: USGS Miscellaneous Field Studies Map, pamphlet and 1 plate, 1:50,000 scale (in prep.)

Richins, W.D., Smith, R.B., Langer, C.J., Zollweg, J.E., King, J.J., and Pechmann, J.C., 1985, The 1983 Borah Peak, Idaho, earthquake: Relationship of aftershocks to the mainshock, surface faulting, and regional 
tectonics: U.S. Geological Survey Open-File Report 85-290, p. 285-310. Savage, J.C., Lisowski, M., Presc ot t, W.H., 1985, Strain accumulation in the Rocky Mountain states: Journal of Geophysical Research, v. 90, p. 1031010320 .

Schwartz, D.P., and Coopersmith, K.J., 1984, Fault behavior and characteristics of earthquakes--examples from the Wasatch and San Andreas fault zones: Journal of Geophysical Research, v. 89, no. B7, p. 5681-5698. Scott, W.E., and Shroba, R.R., 1985, Surficial geologic map of an area along the Wasatch fault zone in the Salt Lake Valley, Utah: USGS Open-File Report 85-448; 2 plates, scale $1: 24,000$.

Scott, W.E., McCoy, W.D., Shroba, R.R., and Rubin, Meyer, 1983, Reinterpretation of the exposed record of the two last lake cycles of Lake Bonneville, Western United States: Quaternary Research, v. 20, no. 3, p. 261-285.

Scott, W.E, Pierce, K.L., and Hait, M.H., Jr., 1985, Quaternary tectonic setting of the 1983 Borah Peak earthquake, central Idaho: Bulletin of the Seismological Society of America, v. 75, no. 4, p.1053-1066.

Smith, R.B., 1986, Significance of the 1983 Borah Peak, Idaho, earthquake: Title submitted for USGS Professional Paper, expanded abstract available. Smith, R. B., and Bruhn, R.L., 1984, Intraplate extensional tectonics of the Western U.S. Cordillera: Inferences on structural style from seismic reflection data, regional tectonics and the rmal-mechanical models of brittle-ductile deformation: Journal of Geophysical Research, v. 89, p. 5733-5762.

Smith, R.B., Eddington, P.K., and Leu, L.L., 1984, Strain rates in Utah from seismic moments, paleoslip, and geodetic surveys: U.S. Geological Survey Open-File Report 84-763, p. 422-437.

Smith, R.B., Richins, W.D., 1984, Seismicity and earthquake hazards of Utah and the Wasatch Front: Paradigm and paradox: U.S. Geological Survey OpenFile Report 84-763, p. 73-112.

Smith, R.B., Richins, W.D., and Doser, D.I., 1985, The 1985 Borah Peak, Idaho, earthquake: Regional seismicity, kinematics of faulting and tectonic mechanism: U.S. Geological Survey Open-File Report 85-290, p. 236-263.

Snay, R.A., Smith, R. B., and Soler, T., 1984, Horizontal strain across the Wasatch Front near Salt Lake City, Utah: Journal of Geophysical Research, v. 89, p. 1113-1122.

Wheeler, R.L., 1986, A statistical analysis of segmentation of the Wasatch fault: Title submitted for USGS Professional Paper; expanded abstract available.

Wood, S.H., 1984, Contemporary vertical tectonics along the Wasatch fault zone measured by repeated geodetic leveling: U.S. Geological Survey open-File Report 84-763, p. 269-285.

Zoback, M.L., 1984, Constraints on the in-situ stress field along the Wasatch Front: USGS Open-File Report 84-763, p. 286-309.

1986, Interpretation of a $30 \mathrm{~km}$ seismic reflection profile across the Wasatch fault zone near Nephi, Utah: Title submitted for USGS Professional Paper, expanded abstract available.

Zollweg, J.E., and Richins, W.D., 1985, Late aftershocks of the 1983 Borah Peak, Idaho, earthquake and related activity in central Idaho: U.S. Geological Survey Open-File Report 85-290, p. 345-367. 
THE GROUND SHAKING HAZARD AND

VARIOUS ASPECTS OF LOSS ESTIMATION

IN THE WASATCH FRONT REGION OF UTAH

\author{
Prepared For \\ Workshop on Earthquake Hazards Along the Wasatch Front \\ Salt Lake City, Utah \\ July, 1986
}

By

Delbert B. Ward, Structural Facilities, Inc.

Albert Rogers, U.S. Geological Survey

Robert Smith, University of Utah

\title{
BACKGROUND OF THE RESEARCH EFFORT
}

A multi-year program, begun in 1984 , to focus research and implementation efforts upon earthquake hazards and risks of Utah's Wasatch fault sets the theme for this paper. With two years of the initial three-year program effort now concluded, and with the third and final year's effort just getting underway, it is timely and appropriate to examine

* Workshop reports were prepared by different triad groups for several components of research and implementation efforts dealing with earthquake hazards along Utah's Wasatch Front. Triad reports were presented at the outset of workshop discussions of the respective agenda subjects and were intended to stimulate further discussions and to provide an overview of recent research and implementation work as well as a subjective evaluation of the significance and progress of the work.

1 Editors Note: See Appendix B for list of strong motion instruments in Utah. 
what has been accomplished to date, to review objectives drafted more than two years ago that were intended to guide the effort, and to offer a critical assessment of the effort to date.

A comprehensive draft work plan for the overall effort, which was created at the outset, contains five interrelated components :

Information systems
- Synthesis of geological and geophysical
data for evaluation of earthquake hazards
Ground motion modeling
- Loss estimation models
o Implementation

This paper deals only with the third and fourth components--namely, ground motion modeling and loss estimation models.

\section{OBJECTIVES STATED IN THE 1984 DRAFT WORK PLAN}

Each component of the 1984 draft work plan included statements of goals, objectives, and tasks to guide the individual element work effort. We repeat here portions of the statements that deal with ground motion modeling and loss estimation models which we deem important to the purposes of this paper.

\section{Ground Motion Modeling}

As stated in the 1984 draft work plan:

"This component is concerned primarily with the prediction of the effects of local geologic site conditions on ground shaking in the salt Lake City region. ... the application, extension, and validation of relevant research techniques will be continued in the Salt Lake City area and along the Wasatch front."

Three priorities of effort were set forth in the draft work plan.

(1) Install strong-motion accelerographs in the Salt Lake City area, and acquire and use the 
mini-Sosie portable reflection system in ground-response research.

(2) Prepare a synthesis report of the ground shaking data available from prior studies in Utah.

(3) Extend the results of these studies, performing deterministic and probabilistic hazard analysis and utilizing new equipment to acquire basic data.

Five specific tasks were outlined for this component.

o Preparation of a synthesis report using ground response data in the Salt Lake CityOgden-Provo-Logan-Cedar City area derived from nuclear-explosion ground-motion data which has been published but not synthesized.

o Application in the Wasatch Front urban areas of research on deterministic and probabilistic hazard analysis, and extended using timedependent models of earthquake occurrence.

o Application of a methodology to zone the ground shaking hazard in the Wasatch Front region, using geotechnical factors to predict how site conditions will influence ground motion during an earthquake.

o Research with high frequency techniques to determine subsurface conditions within the Wasatch Front study area that are known to exhibit high ground response.

- Preparation of revised estimates of the prababilistic ground-shaking hazard in the Salt Lake City region, including maps of peak acceleration and intensity for exposure periods of 10,50 , and 250 years.

\section{Loss Estimation Models}

As stated in the 1984 draft work plan:

"In this component all available hazards data 
will be used in the development of economic

loss (risk) and casualty estimates."

Three priorities of effort also were set forth in the draft work plan for this component.

(1) Update the existing building inventory in Salt Lake City (especially concerning highrise buildings), and create an inventory for lifeline systems.

(2) Establish building inventories and lifeline system inventories in other parts of the study area, seeking to achieve uniformity with the Salt Lake City inventories.

(3) Reassess the vulnerability relationships for Utah.

Two specific tasks were outlined for this component.

- Research on earthquake loss studies, placing primary emphasis on the Salt Lake City, Ogden, and Provo metropolitan areas, consisting of four sub-tasks.

-- Upgrade the existing building inventory in Salt Lake City.

-- Develop an inventory of buildings in other parts of the study area.

-- Reassess vulnerability relationships for Utah, utilizing new data from the Coalinga and San Fernando earthquakes.

-- Develop additional data on the distribution and vulnerability of 1 ifeline systems in the Salt Lake City-Ogden-Provo areas.

- To the extent possible, acquire the same data, as identified in the first task, for other counties in Utah, and perform loss estimates. 

Sector Effort

Although many of the specific work tasks outlined in the 1984 draft work plan were built upon on-going work of the U.S. Geological Survey, it must be emphasized that the multiyear research and implementation effort dealing with earthquake hazards of Utah's Wasatch Front region was envisioned as a combined effort engaging the skills and interests within state and local governments as well as university researchers and professionals in the private sector to supplement the federal effort. The program has proceeded this way even as the U.S. Geological Survey has served heavily in the roles of task initiation, coordination, and funding support.

Given that the Wasatch Front earthquake hazards project has been a combined effort, one must look at research and implementation efforts among all of the aforementioned participants in order to gain an appreciation of what has been accomplished to date. Although we, the authors, are aware of various earthquake hazards study efforts by many participants, we have not tracked systematically the research and implementation efforts, and we make no representation here that all relevant work has been acknowledged. We note, however, that our draft summary of the work has been supplemented by additional information obtained during the workshop, and we have incorporated that additional information into this final version of the paper.

\section{ACCOMPLISHMENTS OF THE PROGRAM TO DATE}

Figures 1 and 2 provide a synoptic overview of research and implementation efforts during the past three years which were aimed at providing improved understanding of the earthquake hazards and risks in Utah's Wasatch fault region. Figure 1 deals with the ground motion modeling component of the draft work plan; Figure 2 deals with loss estimation models for the study area.

The two figures, which have identical formats, represent our attempt to compare research and implementation efforts with the priorities and tasks outlined in the 1984 draft work plan that appear earlier in this paper. In the figures, we have recorded abbreviated titles of research and/or implementation projects for the two components of which we 
Reported 1984 Workshop

Reported -

1985 Conference Reported 1986 Workshop

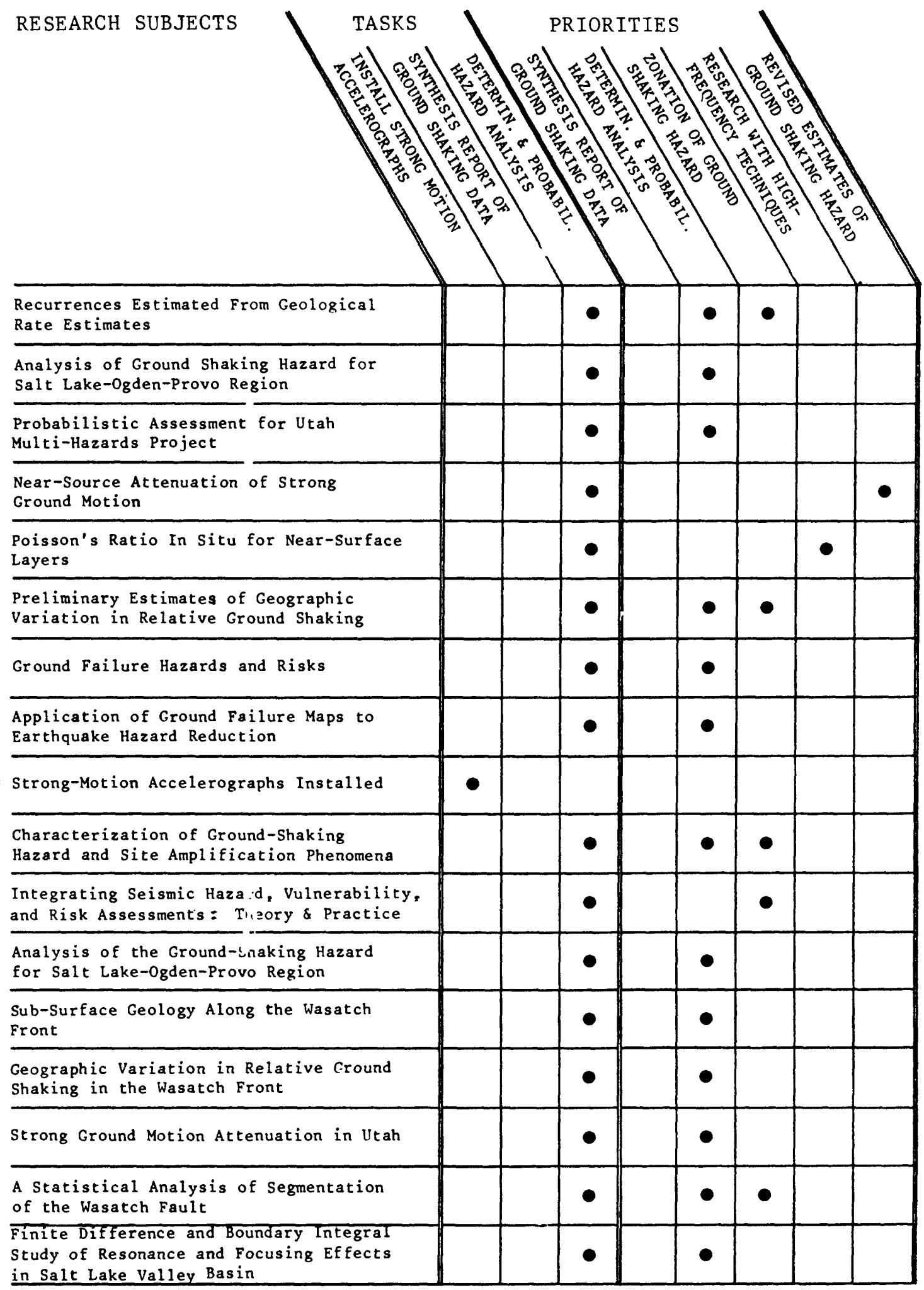




\section{A PROGRESS ANAIYYSIS}

EVALUATION OF EARTHQUAKE HAZARDS AND RISK IN UTAH

\section{LOSS ESTIMATION MODELS}

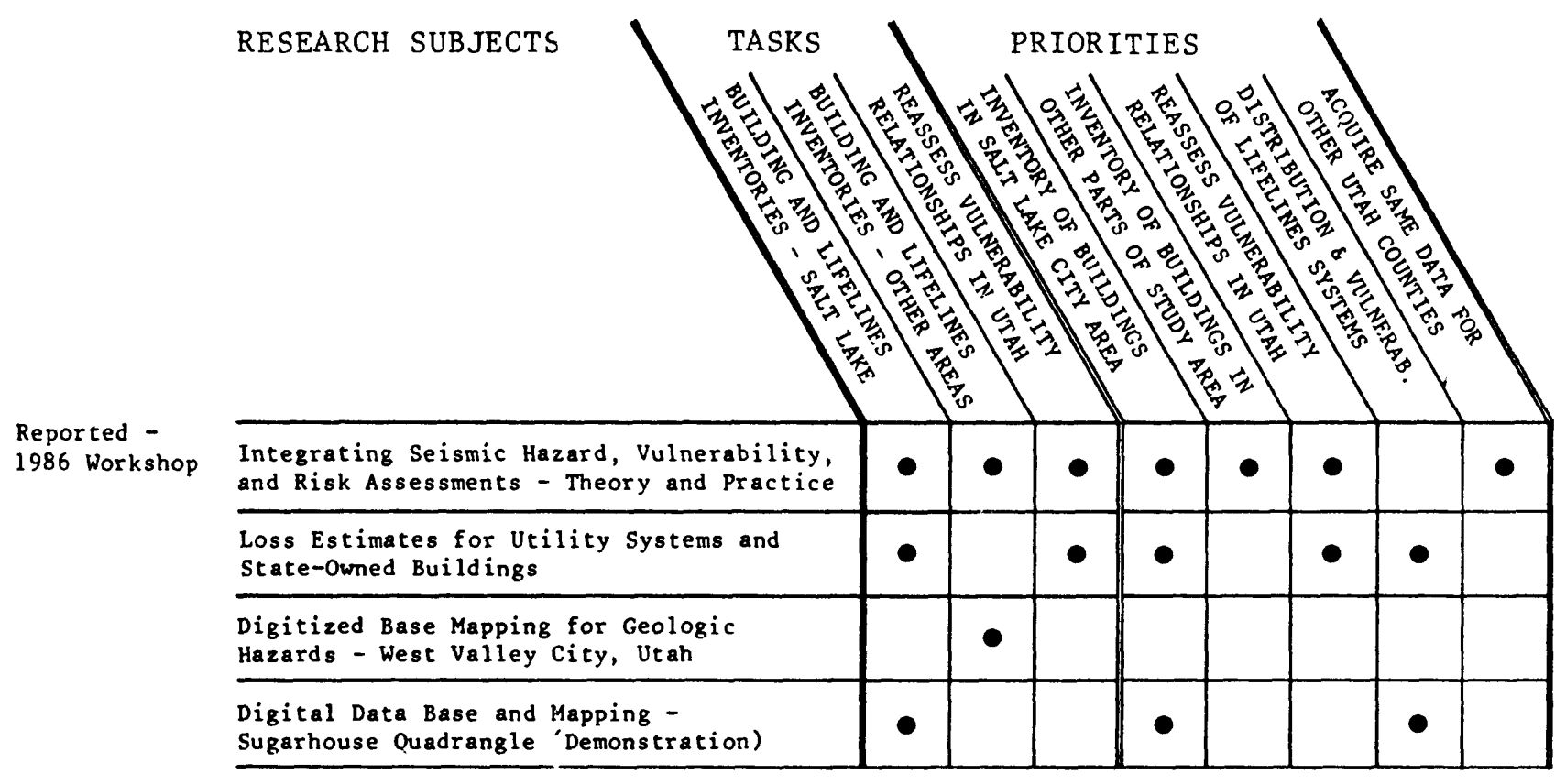


are aware. Using our best judgement, we have assigned these efforts to one or more of the priority and/or task designations. Some of the projects are drawn from proceedings of previous workshops plus this current workshop which were convened as a part of the overall earthquake hazards program for the region. Other projects listed in the figures--some of which have been published and some of which are just underway--are drawn from the combined knowledge of workshop participants and the authors.

To the extent that the authors' judgements and assignments of projects to categories shown in the figures are reasonable, one can see at a glance the extent to which priorities and tasks have been met. These figures are not intended to suggest anything about whether or not the research work has yielded reliable answers to fundamental questions which remain to be answered concerning earthquake hazards and risks in the study area.

Figure 1 reveals that a great amount of research attention has been given to the ground motion modeling component. Only one priority--the preparation of a synthesis report on ground shaking data--has not been met. Although the deterministic and probabilistic hazard analysis element is very general and so encompasses most of the research projects, the listing of research subjects reveals that the research effort has treated a diverse range of problems.

Albert Rogers has provided a more detailed summary of the research effort and accomplishments, treating the ground motion modeling component in three parts rather than as a single element as indicated in Figure 1--namely, source, transmission path, and site effects. This expansion of the component into sub-components is helpful to understanding interrelationships of the research work. Accordingly, his summary of significant accomplishments is reproduced here to further indicate the breadth of the research effort.

\section{Source}

Significant accomplishments --

-- Revised segmentation of the Wasatch Front

-- New segmentation slip rates for some segments

- Suggestion that slip rates are related to 
paleo-lake level

-- Discovery that some scarps in the Great Basin may be terminated by detachment faults at shallow depths

-- Successful testing of experimental highfrequency reflection techniques for studying Quaternary fault geometry and exploration for Quaternary faults

-- Discovery of strike-slip faulting in both the geologic and seismic records for a portion of the Colorado Plateau-Basin-Range Transition Zone

- Reaffirmation of segmentation from the Borah Peak earthquake

\section{Transmission Path}

Significant accomplishments --

- Revised peak acceleration and velocity curves for western Utah based on regression models and a world-wide strong motion data set

High and low $Q$ versions

\section{Site Effects}

Significant accomplishments --

- Measurements of site effects in several

Wasatch Front urban areas

- Replication of site response factors in Salt Lake City

- Successful testing of the capability of high frequency reflection techniques to map the thickness of reflectors in the upper 200 feet

-- Successful testing of $\mathrm{P}$ - and S-wave high frequency techniques to measure Poisson's ratio in near-surface sediments 
-- Evaluation of geologic site conditions at some nuclear-burst recording sites and strong motion instrument sites -- lithology, shear velocity, and thickness

Figure 2 suggests that less research and implementation effort has been directed to the loss estimation models component of the draft work plan than has been directed to the ground motion modeling component.

Although a cursory glance at Figure 2 would suggest that each of the work priorities and tasks has been addressed in the research, this is only partially true for those elements that deal with inventories in areas of Utah outside Salt Lake City. Furthermore, one project of the four listed is just underway and another, the digital data-based mapping of salt Lake's Sugarhouse Quadrangle, is an experiment to explore the feasibility and usefulness of computer-based mapping of hazardous conditions. Of the remaining two projects listed, only one-namely, loss estimates for utility lifeline systems-is completed and published. The more comprehensive project dealing with building inventories and loss estimates for these facilities is near completion, and some findings have been reported, but the inventory details are not yet

generally available.

From the assessment stated above, one can conclude that the loss estimation models component is being attended to, and that some scattered information is becoming available, but no systematized and comprehensive results are yet in place.

With respect to the issue of "reliable answers to fundamental questions," the authors have chosen to not make an assessment at this time. Before this is done, we strongly suggest that synthesis of the completed research work must be done and, especially, that appropriate uses for proposed models be described to supplement the research concepts. More is said on this subject in the next section of the paper which deals with recommendations for additional research in the next few years.

\section{RECOMMENDATIONS FOR ADDITIONAL RESEARCH}

The recommendations for additional research which are made in this section reflect the aggregated views of (1) the 
authors of the Triad III report, (2) three independent workshop discussion groups, and (3) workshop participants as a whole. Suggestions were accumulated at different times during the workshop from each of the three groups named. The challenge for the authors of this paper has been to assemble and report the suggestions in a fair and comprehensible fashion.

Before listing the recommendations, we emphasize that there was no overall procedure established for evaluating the merits of individual recommendations or ranking of them in order of importance by workshop participants as a whole. Thus, it would be improper to suggest or conclude that there is any consensus view reflected by the fact that any particular recommendation is included. The best that can be said is that many of the recommendations were developed by the three discussion groups working independently and often were repeated by more than one group. Thus, the recommendations included herein, at very least, were deemed important by more than just one person.

The recommendations for additional research are divided into two broad classifications--namely, (1) those that deal with a general or philosophical issue, and (2) those that are quite specific as to research problem or task. Within the second classification, recommendations are further divided into one or the other of the ground motion modeling or loss estimation models components.

\section{General Recommendations}

Recommendation: Differentiation is needed between concept models (ideas that research seems to validate) and applications models (concepts that have been reasonably verified or generally accepted).

Discussion: Earthquake hazards studies seem to hold interest for distinctly different reasons among two different groups--namely, scientists who develop new concepts and models that better describe earthquake phenomena and effects, and applications-oriented people who attempt to use state-of-the-art information and methodologies for evaluating hazards and risks. Given the accelerated pace at which research on earthquake hazards in the Wasatch Front region is taking place, it is increasingly difficult for the applications-oriented group to differentiate between 
reported research results which simply (or not so simply) describe a new concept or a new way of looking at a particular problem, and new research results that present valid and accepted methodologies or models which can be substituted for older methodologies or models.

Based upon these conditions, the recommendation is that the next phase of research effort in Utah's Wasatch Front region be structured in a manner that

acknowledges and is responsive to at least three levels of interest and use:

(1) Basic research in which exploration of new concepts and development of new or modified old models is encouraged and supported.

(2) Analysis and validation of concepts from basic research, with the goal of developing and refining the best or most suitable ones for application.

(3) Applications and implementation support in which validated concepts and models are stated in the most simple terms and then suitably described by means of guidelines for use outside the research community.

The second level cited above is an entirely new element for the program, as is a part of the third level that calls for simplification of concepts and models plus guidelines for application.

Recommendation: Elements of the original 1984 draft work plan dealing with ground motion modeling and loss estimation models, which initially were given high priority but which were not completed during the three-year period just ending, should be completed as expeditiously as possible--in particular, the synthesis report on ground shaking data.

Discussion: An examination of Figures 1 and 2 suggests that the original draft work plan has not been completed. We recognize that some priorities and tasks require more than a three-year effort, and that some activities cannot take place until other research work is done--e.g., preparing loss estimates. However, on the assumption that the original draft work plan 
priorities and tasks remain valid, the incompleted work now must be given greater priority than it received during the previous three years. Notwithstanding the fact that certain basic research still is needed, it also is a fact that basic research could be extended into a never-ending activity. This should not be allowed to happen at the expense of bringing other elements of the earthquake hazards program up to a state-of-the-art level.

\section{Specific Recommendations}

Ground Motion Modeling

Recommendation: Efforts must be continued to obtain strong ground motion records in the Wasatch fault region.

Discussion: Although a few strong ground motion accelerographs have been placed at free-field locations in the Wasatch Front region, in accordance with one priority of the initial draft work plan, the strong ground motion instrumentation initiative has not been fully realized. Regardless of difficulties that may arise in obtaining funding for these recording instruments, either from local or federal sources, the need is real for strong ground motion records both for free-field sites and for structures. Efforts to achieve a modest distribution of instruments for both types of sites throughout the region must be continued.

Recommendation: Studies of segmentation of the Wasatch fault, including studies of slip rates of segments, should be continued for the purpose of determining significance of this characteristic to earthquake effects.

Discussion: Studies of segmentation characteristics of the wasatch fault have raised important new questions that need attention beccause of possible implications for hazard and risk analysis. One of the questions is: Is there a directivity effect of fault rupture that alters distribution of intensity levels? Another is: What is the significance of segment length to risk and loss estimates?

Recommendation: Studies of wasatch fault geometry should be continued giving increased emphasis to subsurface reflection 
studies.

Discussion: Tilt angles of fault planes have been shown to affect significantly ground motion intensity distributions and, consequently, risk and loss estimates. Due to the fact that geometry of the Wasatch fault (tilt is downward from east to west) has a relationship with built-up areas along the west face of the wasatch range, the feature needs full consideration in attenuation curves that may be developed for applications effort. The question of possible directivity of fault rupture has similar implications for attenuation and subsequent loss estimates which must be addressed.

Recommendation: Measurements of $Q$ (a crustal property affecting attenuation of ground motions) at frequencies of engineering importance should be undertaken in the Wasatch Front region.

Recommendation: Spectral attenuation functions for the Wasatch Front region should be developed, with an ultimate goal of providing a set of standard curves that encompass the numerous attenuation relations.

Discussion: The point has been raised that research has led to too many attenuation relations and that, while all of these may be of scientific interest, they ought to be simplied in some fashion for applicationsoriented users.

Recommendation: New near-surface stratigraphic framework concepts should be applied to older data for the purpose of evaluating how subsurface conditions affect ground accelerations.

Recommendation: Collection of data on site response and reflection and from boreholes should be continued.

Recommendation: Geotechnical-site response correlations should be completed, leading to extrapolated site response maps for the principal metropolitan areas along the Wasatch Front region.

Discussion: The 1985 Mexico earthquake revealed that basin deposits can affect site response significantly, even from distant earthquakes. Suspected similarities 
between Mexico City and Wasatch Front near-surface deposits should be thoroughly investigated and the resulting findings incorporated into site response functions for the wasatch Front region.

\section{Loss Estimation Models}

Recommendation: Data from building and lifelines systems inventories, including fragility classifications, that have been completed for some communities should be assembled in systematic fashion and made available to other potential users in the study area.

Discussion: Although considerable inventory and loss estimation data on some communities in the study area have been compiled, this information appears in scattered research reports or, in the case of some data, has not been made available at all. If this information is to benefit others in the study area, it must be assembled in some kind of order and made available.

Recommendation: Loss estimates should be prepared for earthquake scenarios of 6 to 7 Richter magnitude events in selected areas of the Wasatch Front region.

Discussion: Loss estimates that have been completed or are being made to date all have been based upon worstcase events (large magnitude earthquakes). Loss estimates based upon worst-case events, while valuable for some purposes, may be misleading for less severe earthquake events because there are nonlinear relationships between earthquake strength and damage. Other earthquake scenarios are needed so that a broader perspective of $r$ isk is available for consideration in development of public policy for earthquake hazards reduction.

Recommendation: Studies recently completed providing loss estimates for public water supply systems and natural gas systems should be assembled in simplified form for use as prototypical examples of the loss estimation process so that they can be more easily used by other implementers in the study area.

* * * * * * *




\title{
GROUND FAILURE, ROCK FALLS AND TECTONIC DEFORMATION \\ IN THE WASATCH FRONT AREA
}

\author{
by \\ Loren R. Anderson, T. Leslie Youd, and Earl E. Brabb
}

\section{OBJECTIVES OF THE RESEARCH DURING THE PAST THREE YEARS}

The objective of the research in this element was directed toward the collection and analysis of geological, seismological and engineering (geotechnical) data for the definition of the ground failure hazard. The studies sponsored by the USGS Earthquake Hazard Reduction Program were specifically targeted toward the liquefaction, landsliding and tectonic subsidence hazards.

Other natural hazard studies were carried out under the sponsorship of the USGS, UGMS and other agencies. The floods, landslides, and debris flows during the spring and summer months of 1983 and 1984 caused a significant effort to be directed toward understanding and mitigating non-earthquake induced landslides and debris flows. USGS, UGMS and the U.S. Forest Service all directed major efforts in responding to these events. Although the work was carried out in an emergency response mode with only minimum documentation it never the less contributed significantly to the engineering and scientific communities understanding of landsliding hazards along the Wasatch Front. In addition to the emergency response activities carried out largely by agency personnel, several other research studies were carried out unders the sponsorship of USGS, UGMS, the U.S. Forest Service and FEMA. Most of these studies were informally coordinated with the eathquake induced ground failure studies and they have tended to augment each other.

The products of this element are to be translated maps of the ground failure harzard for the Wasatch Front. The seven specific studies sponsored by the Earthquake Hazard Reduction Program include:

- Development of Liquefaction Potential Maps for Davis, Salt Lake, Utah, Weber, Box Elder and Cache counties (Four separate studies).

- Developmentof Seismic Slope Stability Maps for Davis, Salt Lake, Utah, Weber, Box Elder and Cache counties (Two separate studies). 
- Evaluation of Potential Consequences of Earthquake - Induced Tectonic Subsidence Along the Wasatch Front, North - Central, Utah.

\section{EXTENT TO WHICH RELIABLE ANSWERS HAVE BEEN OBTAINED}

Of the seven studies listed above five have been completed and final reports have been prepared and submitted to USGS and to other federal, state and local agencies and to many private businesses (Anderson and others, 1982; Anderson and others, 1986a; Anderson and others, 1986b; Keaton and others, 1987; and Keaton, 1987). The two studies that are yet to be completed include the Liquefaction Potential Mapping Study for Weber, Box Elder and Cache counties, Anderson and Keaton (1985) and the Seismic Slope Stability Study for Utah, Weber, Box Elder and Cache counties, Keaton and Anderson (1985). These two studies are well under way and should be completed within this year.

In all cases where the maps have been completed they are reliable and can be considered as translated maps. The maps have been distributed to the appropriate county agencies and are being used in earthquake hazard mitigation activities within the counties. The Liquefaction Potential Map for Salt Lake County is included in a draft ordinance that the Salt Lake County Planning Department has prepared that deals with natural hazard mitigation. The Liquefaction Map for Utah County is also being used in a hazard mitigation program that is being carried out by Utah's Department of Comprehensive Emergency Management. It has been included as one of a series of overlay maps that deal with natural hazards. The use of these maps to date illustrates that the maps can be used in a meaningful way by county planning departments and other organizations charged with the responsibility for natural hazard mitigation.

In generating the maps most of the available subsurface data for the study areas was collected and cataloged. This data is currently available from the Department of Civil and Environmental Engineering at Utah State University. The data has been used by several other studies sponsored by the earthquake hazard reduction program.

\section{SIGNIFICANT ACCOMPLISHMENTS}

The most important accomplishment of the ground failure element of the earthquake hazard reduction program during the past several years has been the publication of: 1) the Liquefaction Potential Maps for Davis, Salt Lake and Utah counties, 2) the Seismic Slope Stability Maps for Davis and Salt Lake counties and 3) the Tectonic Subsidence Maps for the Wasatch Front. The publication of these maps is significant because they represent the first product from the Earthquake Hazard Reduction Program that is translated science and that can be used directly by public agencies to implement earthquake hazard mitigation programs. This in no way implies more importance to these 
studies than to the many studies of the program that have produced scientific products because these scientific products provided the bases for the translated hazard maps.

In addition to the publication of the maps described above there are many supporting products of the study that must be mentioned. These supporting products are listed below for each group of studies.

\section{Products of theLiquefaction Studies}

- Subsurface Data from nearly all subsurface investigations that have been performed in the study area. This data has been compiled in an easily accessable format and it is available from the Department of Civil and Environmental Engineering at Utah State University. The information includes:

1) Boring Locations

2) Boring Logs

3) Brief summaries of subsurface conditions for some areas.

- Shallow Ground Water maps for the study areas. These maps are an interpretation of the data that was obtained from the subsurface information. They indicate ranges in depth to first ground water for the study areas.

- Liquefaction Potential maps for the study areas. These maps are the main product of the liquefaction studies and represent translated hazard maps.

\section{Products of the Seismic Slope Studies}

- Digital topography for 19 quadrangles in Davis and Salt Lake counties.

The data has been compiled for a 30 meter by 30 meter grid (UTM coordinates) and it includes the following information: 1) elevation, 2) slope, 3) slope aspect, 4) down slope curvature and 5) cross slope curvature. The data is stored on magnetic tape and it is available from the Department of Civil and Environmental Engineering at Utah State University.

- Soil Properties Map for the study area. This map was developed using the data that was collected during the liquefaction studies and the surficial geologic maps that were developed by Miller $(1980,1982)$.

- Seismic Slope Stability Maps for Davis and Salt Lake counties. These maps are the main product of the seismic slope stability study and 
represent translated hazard maps.

\section{Products of the Tectonic Susidence Study}

- Map of the potential for tectonic subsidence due to vertical displacement along the Wasatch fault.

- Map of lake inundation that would result from tectonic subsidence.

- Map of shallow groundwater ponding that would result from tectonic subsidence.

\section{RECOMMENDATIONS FOR RESEARCH IN THE NEXT TWO YEARS}

Three separate group discussions on future ground failure hazard research needs were held during the 1985 USGS Utah workshop on earthquake hazards and risk. The general conclusions of each group were:

- Complete the studies that have been funded on ground failure hazard mapping.

- Initiate implementation programs that will utilize the ground failure maps that have been developed. This step is essential and must be a high priority activity of the earthquake hazard reduction program.

- Support the County Geologist program that has been introduced by the USGS Earthquake Hazard Reduction Program.

- Conduct other studies along the Wasatch Front that will help us better understand the relationship between the initiation of liquefaction and the resulting ground failure. Similar studies would be applicable for seismic slope stability.

In carrying out implementation studies consideration must be given to other earthquake hazards in addition to the earthquake induced ground failure studies. Furthermore, for the implementation studies to be complete they must also include other significant natural hazards. 


\section{REFERENCES}

Anderson, L.R., Keaton, J.R., Aubry, Kevin, and Ellis, S.J., 1982, Liquefaction potential map for Davis County, Utah: Utah State University and Dames \& Moore, Final Report for U.S. Geological Survey Earthquake Hazards Reduction Program, Contract \#14-08-0001-19127

Anderson, L.R., Keaton, J.R., Spitzley, J.E., and Allen, A.C., 1986a, Liquefaction potential map for Salt Lake County, Utah: Utah State University and Dames \& Moore, Final Report for U.S. Geological Survey Earthquake Hazards Reduction Program, Contract 14-08-0001-19910

Anderson, L.R., Keaton, J.R., and Bischoff, J.E., 1986b, Liquefaction potential map for Utah County, Utah: Utah State University and Dames \& Moore, Final Report for the U.S. Geological Survey Earthquake Hazards Reduction Program, Contract 14-08-0001-21359.

Keaton, J.R., Anderson, L.R., Topham, D.E. and Rathbun, D.J., 1987, "Earthquake-Induced Landslide Potential in and Development of a Seismic Slope Stability Map of the Urban Corridor of Davis and Salt Lake Counties, Utah". Dames \& Moore and Utah State University, Final Report for the USGS Earthquake Hazard Reduction Program, Contract 14-08-0001-21913.

Keaton, J.R., Potential consequences of earthquake-induced tectonic deformation along the Wasatch Front, Utah: Utah State University, Final report to the U.S. Geological Survey for Earthquake Hazards Reduction Program Grant 14-08-0001-g1173. 
COLLECTING, COMPILING, TRANSLATING, AND DISSEMINATING

EARTHQUAKE-HAZARDS INFORMATION FOR URBAN AND REGIONAL

PLANNING AND DEVELOPMENT IN THE WASATCH FRONT AREA, UTAH

by

Gary Christenson, Jerold Barnes, Joseph Moore, Craig Nelson, Robert Robison, Mike Lowe, and William Kockelman

\section{OBJECTIVES}

The following objectives relate to collecting, compiling, translating, and disseminating scientific and technical information concerning earthquake hazards:

- Translating information (including hazard location and severity) for use by planners, engineers, and decisionmakers.

- Ensuring effective dissemination of the information to users, including devising systems whereby users will have easy access to information that has useful media, scales, and formats.

- Providing assistance to state and local units of government in assessing hazards, obtaining specific information, and improving access to geologic, seismic, and geotechnical expertise.

- Presenting examples of reduction techniques and experience in their use.

- Incorporating the collection, compilation, translation, and dissemination work into ongoing programs of state and local units of government.

\section{ASSESSMENT}

Many projects have just begun or rely upon the results of other projects to provide the necessary technical or scientific information. Therefore, the extent to which the above objectives have been met is difficult to evaluate. The following work directed to the above objectives

* With assistance from Wendy Hassibe, Jim Tingey, Ralph Findlay, Deedee O'Brien Wendy Dewsnup, Perry Hardin, Bruce Kaliser, and Don Mabey 
was begun or accomplished during the past three years:

Collecting, Compiling, and Translating Information

- Statewide Geologic Hazards Bibliography -- compiled over 2500 published and unpublished maps and reports and indexed them under author and type of hazard (UGMS: Christenson).

- Statewide Earthquake Bibliography -- compiled about 800 references regarding earthquakes and earthquake hazards (UGMS: Mabey).

- Statewide Generalized Hazards Mapping -- planned maps $(1: 750,000)$ showing selected hazards (UGMS: Christenson).

- Building Excavation Inspection Program -- logged over 100 excavations and indexed them by location (UGMS: Gill).

- Wasatch Front Counties Hazards Libraries -- collected and indexed by author, type of hazard, and location over 780 maps and reports for Utah and Juab counties; over 850 maps and reports for Weber and Davis counties; and over 890 maps and reports for Salt Lake County (County planning departments: Robison, Lowe, Nelson).

- Wasatch Front Mapping -- published seven maps $(1: 100,000)$ showing geology, surface water, ground water, and mineral resources (A, B, $C$, and D series) (UGMS: Davis).

o Tooele County Hazard Mapping -- showing lifeline systems and faultrupture $(1: 24,000)$ (CEM: Tingey).

- University of Utah Demonstration Project -- developing a Geographic Information System $(1: 100,000)$ for risk analysis, land-use planning, and earthquake hazards risk reduction for salt Lake County (University of Utah Department of Geography: Emmi, Hardin).

- West Valley City Earthquake Hazards Reduction Program -- creating a geographic-based file and map of selected earthquake hazards to be incorporated into City development policies and ordinances (City of West Valley: Moore).

- Rockfall Potential Mapping -- along the Wasatch Front $(1: 100,000)$ (UGMS: Case).

- Seismic Slope Stability Mapping -- for Davis and Salt Lake counties (USU Engineering Department: Anderson; Dames and Moore, Keaton).

- Liquefaction Potential Mapping -- for Davis, Salt Lake, and Utah counties $(1: 48,000)$ (USU Engineering Department: Anderson; Dames and Moore: Keaton). 

showing areas of subsidence and flooding for several levels of Great Salt Lake and Utah Lake (Dames and Moore: Keaton).

- Utah County Comprehensive Hazard Mitigation project -- including risk mapping, development of a feasible mitigation program, and establishment of an effective mitigation organization (Utah County; CEM: Dewsnup).

- Weber County/Ogden City Multihazards Mitigation Plan -- developed pre-disaster hazard-mitigation strategies and implementation measures (CEM: Dewsnup).

Disseminating Information

- Survey Notes -- publication and distribution quarterly to over 3000 readers (UGMS: Atwood and staff).

- Wasatch Front Forum -- publication and distribution quarterly to about 350 readers; contributions from Federal, state, and local units of government and private individuals (USGS: Hassibe).

- Geologic Hazards Outreach Program -- curriculum developed and made available to schools in the Salt Lake Valley; presentations this year have reached 3000 students in 99 classrooms in 29 schools (UMNH: O'Brien).

- Earthquake Preparedness Packets -- development and distribution of earthquake safety information (CEM: Tingey).

- Earthquake Awareness and Education Program -- including a one-halfhour television program (CEM: Tingey).

- Educational services to state and local units of government -including giving speeches and lectures, responding to public inquiries, publishing lists of publications, encouraging preparedness, maintaining a sales office, distributing one-page hazard information sheets, sponsoring and coordinating workshops and special meetings for users (UGMS: Atwood, Mabey, and staff; CEM: Tempest, Findlay, and staff; USGS: Hays, Gori, Hassibe, Kockelman; County planners and geologists).

- Advisory services to state and local units of government -- on geologic factors affecting risk assessment, hazard identification, siting of critical facilities, detailed hazard mapping, siting of public facilities, siting of debris basins, impact of road cuts, environmental planning, emergency preparedness, and ordinance amendments (UGMS: Kaliser, Lund, Christenson; County planning departments: Robison, Lowe, Nelson).

- Review services (including recommendations) to state and local governments -- on rezoning applications, development permits, geo- 
technical reports, geologic hazards ordinances, location of critical facilities, and proposed annexations (UGMS: Kaliser, Lund, Christenson; County planning departments: Robison, Lowe, Nelson).

- Public Inquiries office -- providing access to or copies of geologic and seismologic reports to over 8000 persons per year; making presentations to civic and school groups (USGS: Hassibe).

\section{MOST SIGNIFICANT ACCOMPLISHMENTS}

Much of the work planned under existing programs is in progress but will not be completed for one or two more years. Under the UGMS Wasatch Front County Geologists Program, a series of translated (interpretive) maps $(1: 100,000)$ depicting hazards along the Wasatch Front are planned along with a report describing these hazards. Collecting and indexing hazards information and providing technical assistance to planners are being emphasized under this program. Under the UGMS Applied Geology Program, statewide hazard maps $(1: 750,000)$ are being completed. Other projects emphasize specific hazards mapping, evaluation of reduction techniques, education, and information dissemination.

Some of the most significant accomplishments to date are:

- Education of planners and decisionmakers in the Wasatch Front area regarding earthquake hazards through meetings, workshops, and placement of geologists on planning staffs in five Wasatch Front counties.

- Creation of county hazard information libraries with ready access to existing hazards information in five county planning department offices.

- Quality control over geotechnical investigations, particularly seismic hazards studies, by providing geological review of reports submitted to local planning agencies.

- Compilation of 1 iquefaction potential maps and reports for three counties.

- Increased communication between earthquake hazards investigators.

- Incorporation of the School Outreach Program into the Museum's overall program, staffing, and budget. 
Because technical and scientific information is a prerequisite for effective implementation, it is recommended that information collected during the first three years be made available for translation and dissemination. It is further recommended that emphasis during the remaining two years of the program be placed on implementation projects. Many of the projects that have been funded will extend into this period, but priority should be assigned to projects which:

- Continue the building excavation inspection program (UGMS staff).

- Continue the compiling of the statewide hazards bibliography (UGMS staff).

- Provide occurrence intervals and severity of various hazards to give planners and decisionmakers a basis for estimating risk (USGS staff and grantees).

- Provide State and local hazards susceptibility maps and reports (County geologists; UGMS staff; USGS grantees).

- Develop guidelines for local governments to use in writing earthquake-hazards ordinances (UGMS staff).

- Continue providing educational, advisory, and review services aimed at State and local planners and decisionmakers (UGMS staff; USGS staff; County geologists; CEM staff; Museum staff).

- Incorporate collecting, compiling, translating, and disseminating work into ongoing programs of state and local governments.

During the past two years, some additional needs have been identified; the following specific needs should be assigned priority:

- Developing model ordinances, which address earthquake hazards, for local governments.

- Collecting examples of reduction techniques for each hazard, and evaluating them for effectiveness. 
Status of work on collecting, compiling, translating, and disseminating earthquake-hazards information for urban and regional planning and development in the Wasatch Front area, Utah

Topic

Status

(fifths completed)

(c = continuing)
Recommended priority for the next 3 to 5 years

\section{A. Collecting and compiling work}

1. Statewide geologic and earthquake hazards

$12(3) 45$

(1) 23 bibliographies (UGMS)

2. Building excavation inspection program (UGMS)

12345 (C)

(1) 23

3. County geologic hazards libraries (Co. geologists)

$123(4) 5$

\section{B. Work products}

1. Statewide generalized hazard maps (UGMS)

2. Wasatch F ront map series (UGMS)

3. Geology and geotechnical source directory (UGMS)

4. Wasatch Front county hazards index maps (Co. geologists)

5. Utah Co. hazards susceptibility maps and reports (Co. geologist)

6. Juab Co. hazards susceptibility maps and reports (Co. geologist)
(1) 2345

$123(4) 5$

$123(4) 5$

1234 (5)

(1) 2345

(1) 2345

(1) 23

(1) 23

$12(3)$

$12(3)$

I 2 (3) (1) 23 
7. Weber Co. hazards susceptibility maps and reports (Co. geologist)

8. Davis Co. hazards susceptibility maps and reports (Co. geologist)

9. Sal t Lake Co. hazards susceptibility maps and reports (Co. geologist)

10. Earthquake preparedness packets (CEM)

11. Earthquake television program (CEM)

12. Weber Co./Ogden City hazard maps at las (CEM)

13. Utah Co. hazard maps atlas (CEM; Utah Co.)

$12(3) 45$

\section{Dissemination Work}

1. Wasatch Front Forum (UGMS/USGS)

2. Survey Notes (UGMS)

3. Guidelines for local hazards ordinances (UGMS)

4. State educational, advisory, and review services program (UGMS/CEM/USGS staffs)

5. County educational, advisory, and review services program

(County planning department geologists)

6. Geologic Hazards Outreach Program (UMNH)

7. Utah County comprehensive hazards mitigation project (CEM)

8. City of West Valley Program (City)

9. Public Information Office (USGS)

\section{$12(3) 45$}

12345 (C)

$12(3) 45$

12345 (C)

12 :

1 (2) 3

(1) 23

(1) 23

12345 (C) 
DEVELOPMENT AND IMPLEMENTATION OF IMPROVED LOSS-REDUCTION MEASURES IN UTAH

by

\author{
Genevieve Atwood, Utah Geological and Mineral Survey \\ Lorayne Tempest, Utah Division of Comprehensive Emergency Management \\ Gary Johnson, Federal Emergency Management Agency \\ Jerome 01son, Federal Emergency Management Agency
}

GOALS, PRIORITIES, AND OBJECTIVES

The USGS draft workplan FY 84-86 stated the following as the goals and priorities for the first three years' effort towards "Implementation".

Goal--The goal of this component is effective use of scientific information to reduce loss of life and damage to property caused by earthquake hazards as well as by other geologic and hydrologic hazards. Successful achievement of the goal requires COMMUNICATION of TRANSLATED SCIENTIFIC INFORMATION to RESPONSIBLE OFFICIALS and INTERESTED PARTIES seeking to REDUCE HAZARDS by use of one or more REDUCTION TECHNIQUES. These aspects of the problem and its solution will be discussed below, providing a framework for a integrated work plan involving all concerned parties and guidelines for proposals to the USGS's external grants and contracts program.

Priorities-The first priority is to determine the needs of users in Utah for earthquake hazards information. The second priority is to produce translated (i.e., interpreted information derived from basic scientific data) scientific information that meets the needs of these user groups. The third priority is to foster an enviromment for implementation of research results by local govermments, utilizing workshops, training classes, questionnaires and other procedures to communicate the scientific information.

Many loss reduction measures can be developed and implemented when such an environment exists and when information is available. Over the last three years, various state and local entities have attempted to meet the following objectives:

Make information available: Provide information so that informed individuals or entities can make rational decisions on how to cope with the earthquake hazards and risks; provide geologists, planners, decisionmakers, and the public with readily available large scale depictions of earthquake and associated hazards and provide these same groups with readily available large scale depictions of demographic information, lifeline systems, critical facilities and public interest areas of concern.

Educate certain sectors of the community: Target certain key groups of individuals who can reduce earthquake risk and provide them with information so they can implement earthquake hazard reduction. 
Recognize and avoid the hazand: Encourage public sector to avoid earthquake hazards and risks where possible, to engineer for them, and to prepare for them.

Engineer to reduce losses: Improve the capability of existing as well as new buildings to withstand earthquakes.

Preparedness: Prepare govermment and response forces to cope with the potential earthquake damages in order to reduce loss of life, alleviate human suffering, and reduce property losses; reduce losses by preparing public and private sector to cope with hazards associated with earthquakes; create organized cadre of individuals to do post-earthquake evaluations.

$$
\text { 1983-86 - LOSS REDUCTION STUDIES, PROIECTS, AND ACCOMPLISHMENTS }
$$

The last three years efforts have heightened the awareness of Utah's decisionmakers to earthquake hazards and fostered an environment for implementation of research results, but it is the opinion of the "triad" that these achievements are very limited considering the potential for achieving loss reduction. Implementation of loss reduction measures has lagged far behind the advances in scientific/technical knowledge. The following projects have implemented loss reduction:

Make information available

(also refer to Triad IV report: collecting, compiling, translating, and disseminating earthquake-hazards information for urban and regional planning and development in the Wasatch Front Areas, Utah).

State-wide hazards bibliography

State-wide quadrangle hazards mapping

Wasatch Front Forum - Newsletter

Wasatch Front counties hazards libraries (in progress)

Geologic Hazards outreach program of Utah Museum of Natural History

"Disclosure" legislation proposal in the legislature (legislation failed but the basic program of information compilation was funded)

\section{Educate certain sectors of the community}

Targeted agencies - specific workshops

UGMS (role for next 5-10 years and role after a major earthquake)

CEM (workshop for planners and emergency response personnel)

Planning community (translate information to users) 
Building officials - ICBO program to certify plan checkers, certify building inspectors and certify testers

Formal workshops and training

1983 EERI - Regional earthquake hazards in Utah

(approximately 100 registrants)

1985 AIA - Workshop for architects and engineers for seismic design

Conference on lifelines workshop by Mountain Fuel - Craig Taylor

Informal workshops and training

State agencies - UGMS brown bag lunch series for state agency users of earthquake information (Water Rights, Water Resources, issues concerning Great Salt Lake)

The public

Good press coverage; particularly, trenching studies and workshops

Recognize and avoid the hazards

Mapleton City ordinance - 1984

Provo ondinance - 1985

Multi-hazards program in ogden - ordinance adopted, pre-disaster hazard mitigation stratigies can serve as a model program for the Nation

Multi-hazards program in Utah county - risk mapping, development of mitigation program (in progress)

Funding of statewide hazards information compilation

(in progress)

University of Utah geography department's demonstration project for Salt Lake county (in progress)

West Valley City earthquake hazards reduction program. to be incorporated into city development policies and ordinances

(in progress)

\section{Engineer to reduce losses}

Progress in private sector for inspectors largely through activities of ICBO

Little progress with construction standards for new schools (partial failure)

Less plan checking of state facilities (backward step)

Local building departments, codes and enforcement some communities are demanding more information and more responsible development; some have been put under considerable duress 
The USGS deployment of strong motion devices has resulted in local govermment awareness and interest

Legislation was proposed (but failed) that would require entities that charge fees to review plans to review those plans.

Some voluntary retrofit of selected buildings

Some buildings at University of Utah

Some utilities (Mountain Bell)

Some school districts (Davis County-20 schools; Salt Lake City and Granite doing inventories; Alpine District-somewhat)

Salt Lake City and County Building retrofit for historic preservation and for loss of life (in progress)

\section{Preparedness}

Earthquake response plan - CEM has completed plans for state agencies and for four counties (Weber, Davis, Salt Lake, Utah)

Mutual Aid Agreements - CEM has established cooperative agreements between counties, between state and counties for support, and between the military and state for support

UGMS/CEM/Seismograph Stations have written Standard operating Procedures for after a major earthquake (in progress)

Review of Department of Natural Resources Emergency Operation Plan (in progress)

Response to events - (a) post-earthquake investigations of Borah Peak included the engineering community, university community, governmental entities, CEM, UGMS, etc.; (b) landslide and mud flow events of 1983, 1984, 1985 heightened awareness and the preparedness of capabilities of local govermments. In particular, the Thistle landslide provided a prototype for state response to an emergency; (c) the rise of Great Salt lake has shown how expensive and inexorable geologic hazards can be

SPECIFIC RECOMMENDATIONS FOR RESEARCH AND IMPIEMENTATION PROTECTS

TO REDUCE LOSSES

Make information about the hazard available: translate scientific information into a usable format 
Maintain the county geologists program to advise local governmental entities of the earthquake hazards and risks and work directly with their planning departments

Establish UGMS as the repository of earthquake hazards information in Utah with the responsibility to maintain a library of geotechnical information

Establish an Earthquake Information officer at UGMS to be a source of information concerning detailed mapping and studies of earthquake hazards throughout the state. This person should systematically obtain additional data at scales and in formats usable by county and local officials

Prepare information about the hazards that can be understood by laypeople

Develop ways to depict earthquake and associated hazards using computer techniques

Accelerate large scale $(1: 24,000)$ seismic risk and associated hazards mapping for major risk areas

Make information about the risk easily available: facilities at risk, mitigation, preparedness

Develop maps showing location of critical facilities such as lifelines, schools, hospitals and their susceptibility to hazards. Development of computerized overlays of critical facilities and lifelines

Disseminate more definitive information about true risks, directed to specific audiences including actions that can be taken to reduce risk

Develop scenarios for postulated earthquakes of specific magnitude and on specific faults including realistic estimates of where damages will occur

Identify structures and the types of structures that are susceptible to failure

Develop site specific $(1: 2,400$ scale) geologic reports that are legally and politically defensible

Educate certain sectors of the community: identify and target users who have urgent needs and can be expected to use the information most effectively. The possible target groups are numerous: elected officials, local planning commissions and staff, real estate agents, employees of local and state governments, private sector, LDS Church, the press/media, schools/students/parents, hospital and medical personnel, architects and engineers, building inspectors, building contractors, city and county attorneys, etc. 


\section{State of Utah:}

The state legislature should continue funding a core program after the initial three-year funding from USGS is completed.

CEM should develop video programs for public education on earthquake hazards and preparedness and provide "public service announcements" to advise the public on who to call or contact should they desire earthquake hazards information.

The office of State Personnel should recognize that hazards training, identification, mitigation measures, and reporting techniques should be reflected in the job descriptions of many state and local govermment-funded personnel.

The Division of Facilities Construction and Management should assign an engineering geologist to inspect sites for state buildings and other state-financed buildings. This person could be located at UGMS or DFCM.

The Attorney General's Office should take an active lead in developing laws that reflect the issue of liability and natural hazards. Sound legal judgements based on events in other parts of the country should protect the people of the State of Utah from undue hardships caused by natural hazards.

Utah's Department of Transportation should implement a seismic safety program for its highway bridge structures.

The Public Service Commission should review the seismic safety practices of regulated utilities and enforce standards concerning earthquake resistance of public utility systems.

The Board of Education should require that new schools meet appropriate earthquake safety standards.

The Division of Water Resources should see that local water districts identify and correct conditions in water supply systems that are vulnerable to earthquake damage.

\section{Local Government:}

County Hazards Geologists Program should be continued in order to develop information and provide support to planning departments.

Multi-hazards projects such as those in Ogden and in Utah County should be undertaken by many local govermments. 
Statutes should require that local govermments plan for earthquake safety and other geologic hazards.

Ordinances should be set into place requiring that home buyers be informed of studies on earthquake and other natural hazards that may involve property they are interested in purchasing. For each property purchase, a statement of natural hazards should be seen and signed by the potential purchaser of the property.

Create model ordinances that recognize the hazards. Require developers to engineer for the hazard using standards and guidelines that incorporate adequate procedures for planning and siting of developments...particularly critical facilities and lifelines.

Local govermments can use peer review to increase professionalism and better achieve quality reports, especially review of design plans for public schools.

\section{Recognize and avoid the hazard}

The State Building Board should require that geoseismic examination of potential sites for state buildings, hospitals, schools, or any other public facility be made early enough in the decisionmaking process to be incorporated into the choice of a site.

The legislature should require that site evaluations of geologic hazards be made for all public-use facilities.

Local Planning Commissions should require a geologic hazards report before tracts of land are developed.

\section{Engineer to reduce losses}

Continue strong-motion instrumentation programs to obtain needed information about earthquake-induced ground motions in Utah. Develop within the state the capacity to conduct research in strong motion estimation, to analyze strong motion data, and to provide information on strong ground shaking to the engineering community.

Strengthen building code enforcement practices.

Require earthquake safety code provisions in facilities built under state jurisdiction.

Adopt legislation requiring compliance with earthquake safety provisions of the building code. 
Develop and implement abatement programs leading to eventual elimination of existing high hazard, public-owned facilities. Undertake structural analysis of emergency facilities to determine which facilities are the weakest and in need of repair/maintenance. A persistent seismic retrofit program needs to be implemented for these critical emergency services.

Undertake a program of selective retrofit or replacement of high hazard facilities that are essential in our community or that have large occupancy of people.

\section{Preparedness}

Provide secure and reliable communication system for post-earthquake response and recovery activities.

Define agency and professional onganizations' response roles after a major earthquake.

Motivate private sector preparedness. 
QUESTIONNAIRE IV: IMPLEMENTATION OF SPECIFIC ACTIONS TO REDUCE POTENTIAL

LOSSES FROM EARTHQUAKE HAZARDS IN THE WASATCH FAULT, UTAH AREA

Research/Implementation technique

Priority for next

1. Make information available - hazards

a. County geologist program

b. Repository for earthquake information

c. Earthquake Information Office

d. Develop information for laypeople

e. Depict earthquake hazards using computers

f. Accelerate 1:24,000 mapping

2. Make information available - risks

a. Maps of critical facilities, computerize

b. Disseminate site specific information

c. Write scenarios

d. Identify types of structures susceptible to failure

3. Educate certain sectors of the community

a. State legislature

b. CEM and the general public

c. State agency personnel

d. Division of Facilities Construction and Management

e. Attorney General's office

f. Department of Transportation

g. Public Service Commission

h. Board of Education

i. Water Management Agencies

j. Local Government

4. Recognize and avoid the hazard

a. Geoseismic evaluations for critical facilities

b. Site evaluations for all public-use facilities

c. Local government ordinances

5. Engineer to reduce losses
a. Strong motion instrumentation
b. Building code enforcement
c. Require earthquake safety in state construction
d. Legislate compliance with earthquake code
e. Identify critical facilities at risk
f. Retrofit or replace critical facilities

6. Preparedness
a. Communications for post-earthquake response
b. Define agency/other entities' roles
c. Motivate private sector

Status three years

$\begin{array}{llllllll}1 & 2 & 3 & 4 & 5 & 2 & \end{array}$


by

Lawrence Reaveley, Reaveley Engineers \& As sociates, Inc. Delbert Ward, Structural Facilities, Inc. Walter Hays, U.S. Geological Survey

\section{THE UNIFORM BUILDING CODE}

The most widely used standard for earthquake-resistant design is the Structural Engineers As sociation of California (SEAOC) Code. The SEAOC Code, which was incorporated into the 1973 Uniform Building Code, contains the following commentary about aseismic design.

Basica11y, the problem is that the entire phenomenon, from the earthquake ground motion to the realistic response of structures to this ground motion, is very complex. Codes, of necessity are generalized simplifications. Complex mathematical analyses have been made on simple and idealized structures subjected to past earthquake ground motions. These have been helpful in improving our understanding of the phenomenon. However, for purposes of design of the vast majority of structures, it is necessary to reduce this complex, dynamic problem to one of equivalent static lateral forces. These can be related to the dynamic characteristics of the structure. They provide the basic code criteria, applied with stresses within the elastic limit. However, in applying these simplified concept, the structural engineer must do this with sound judgment that can only be developed with experience, observation, and study of the earthquake phenomenon. He must be especially aware of the nature of the response of the particular structure under design and he must evaluate the capabilities of the structure to perform satisfactorily beyond the elastic-code-stipulated stresses.

The Uniform Building Code is a minimum standard to assure public safety. The requirements are intended to safeguard against major failures and 1 oss of 1ife. The aim of the code is to provide structures that wi11:

A. resist minor earthquakes without damage;

B. resist moderate earthquakes without structura1 damage, but with some nonstructural damage;

C. resist major earthquakes without collapse, but with some structural and nonstructural damage.

D. The basic formula used in the current edition (1985) of the Building Code is:

where

$$
\mathrm{V}=\mathrm{ZIKCSW}
$$

$\mathrm{V}$ is the base shear or total lateral force to be resisted at the base of the structure, 
$Z$ is zone factor, based on the Algermissen (1969) U.S. seismic risk map having four seismic risk zones. The numerical values of $\mathrm{Z}$ for the four zones are: $z=1$ for zone $3 ; z=0.5$ for $z$ one $2 ; z=0.25$ for zone 1 ; and $\mathrm{Z}=0$ for zone 0 .

I is the importance factor for the building.

$\mathrm{K}$ is an arbitrary factor that, in effect, is a safety factor adjustment based on an arbitrary classification of the type of construction. It recognizes that different degrees of hazard against collapse are inherent in different types of construction; $K$ has no relation to the actual forces expected.

$C$ is a coefficient related to the period of the structure. A plot of $C$ against period represents a response spectrum and roughly parallels that derived from the 1940 Imperial Valley, California, earthquake accelerogram recorded in E1 Centro, California.

$S$ is the soil-structure interaction factor. It ranges form 1 to 1.5 , the highest value occurring when the building and soll periods are equal.

$W$ is the weight or total dead load of the structure.

THE PROBLEM IN UTAH

Figure 1 shows the information sequence of the building code process. The current situation in Utah is that considerable new knowledge is becoming available on the earthquake potential of specific faults, the ground-shaking hazard, soil amplification, earthquake-induced ground failures, and other phenomena. Also, recent damaging earthquakes (for example, the 1985 Mexico earthquake) have provided earthquake engineers with important information on earthquake-resistant design. This new knowledge has not been incorporated in the current edition of the Uniform Building Code (UBC) nor in design considerations for structures in Utah. This fact raises five questions:

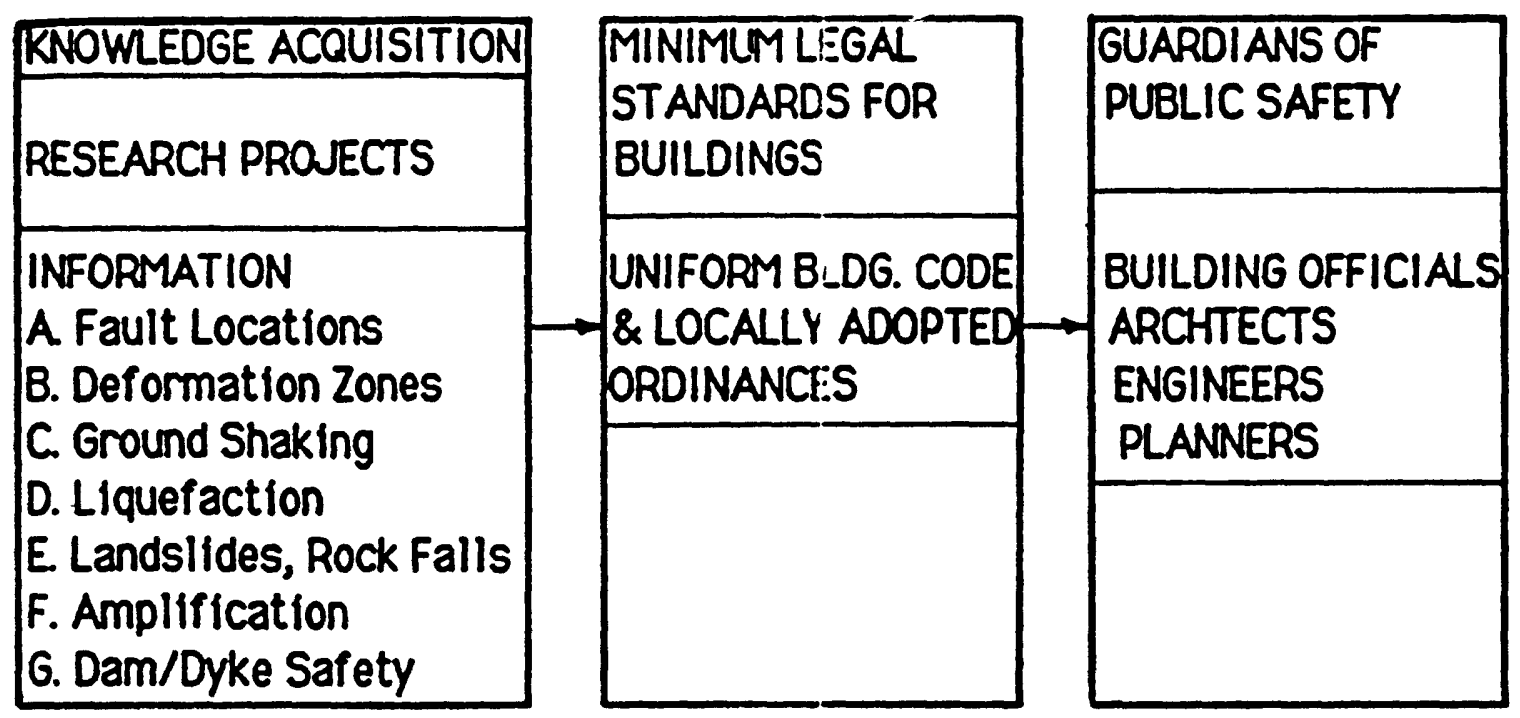

Figure 1.--Schematic flow diagram of the information sequence in the building cude process. 
Question 1: How does information move from research to the UBC?

Question 2: What organization is responsible to put research findings into an acceptable format for inclusion in the UBC?

Question 3: What organization is responsible to put research findings specific to Utah into a format for inclusion in the UBC or locally adopted ordinances?

Question 4: Should the UBC contain localized, detalled, seismic criteria? Question 5: Should the local building officials establish the requirements for their jurisdictions?

RECOMMENDATIONS TO IMPROVE EARTHOUAKE-RESISTANT DESIGN IN UTAH?

The best strategy for improving the UBC for Utah applications appears to have three parts. They should be accomplished within the next 3 years before the 1991 edition of the UBC and are:

A. Update the zoning map which gives the $\mathrm{Z}$ factor. A new more realistic map (Figure 1) was proposed by the Applied Technology Council (ATC) in 1978. It uses the concept of a 50-year exposure time and a 90 percent probability of nonexceedance.

B. Determine if the soil-structure interaction factor is adequate for Ut ah solls

C. Integrate land-use planning and structural design considerations into practice.

To make the building code process work, the following arguments must be resolved in Utah:

Argument 1: The UBC/ATC zoning maps are too generalized to represent the variations in local ground shaking that are expected along the Wasatch front; therefore, a separate zoning map is required for each population center.

Argument 2: The soil effects in Utah are not adequately accounted for by both the UBC and ATC codes.

Argument 3: Local officials do not know enough to establish realistic design criteria.

Argument 4: Local governments will not, in and of themselves, see the need to promote seismic safety.

Argument 5: Architects, engineers, and geologists are inadequately trained in earthquake hazards mitigation.

Argument 6: Political officials do not support their building officials . 


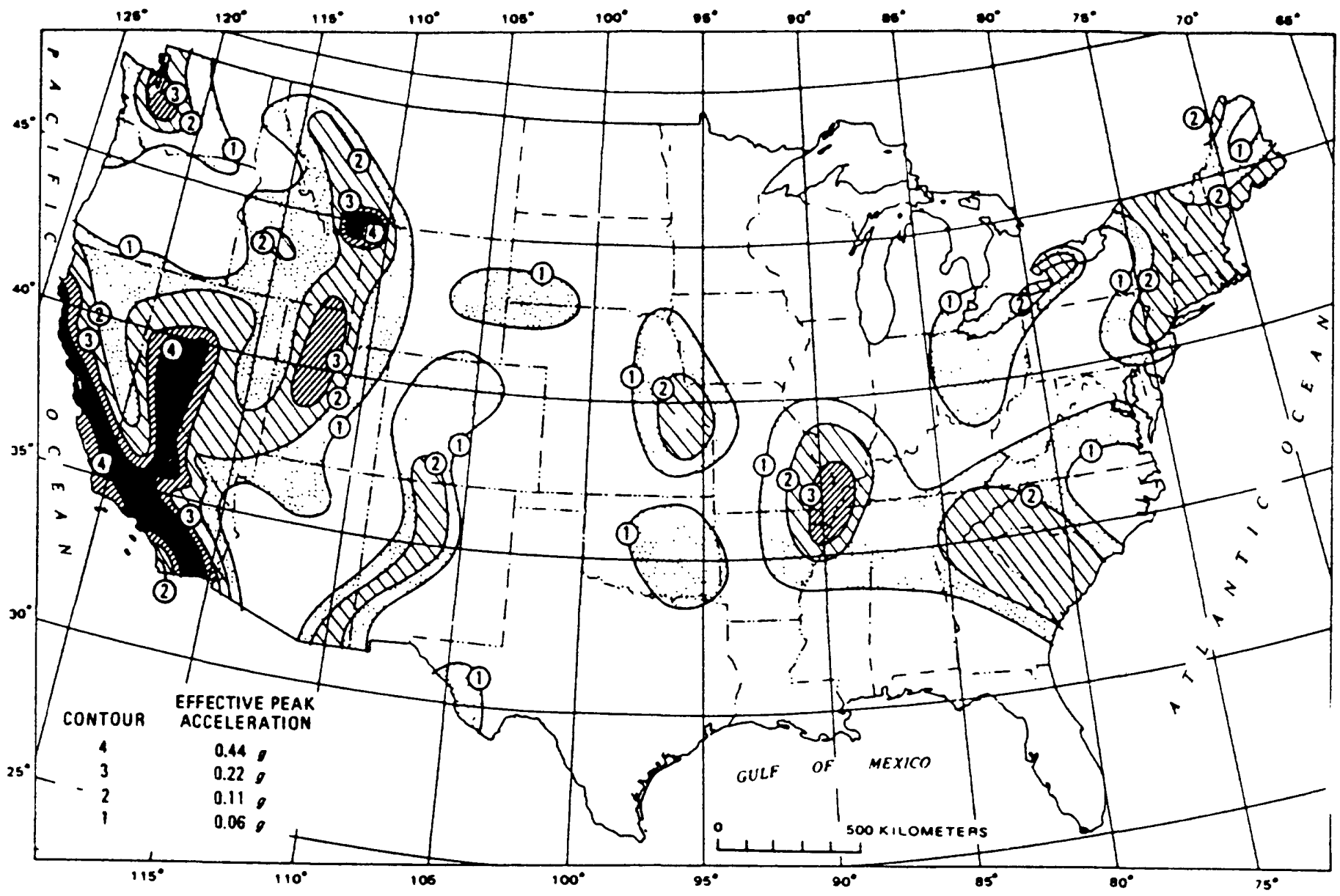

Figure 2.--Preliminary design regionalization proposed for 1976 Uniform Building Code (from Applied Technology Council, 1976). 
APPLYING DIGITAL CARTOGRAPHIC AND GEOGRAPHIC INFORMATION SYSTEMS TECHNOLOGY AND PRODUCTS TO THE NATIONAL EARTHQUAKE HAZARDS REDUCT ION PROGRAM*

by

Robert H. Alexander, Michael P. Crane, Thomas P. DiNardo, Leanne M. Firestone, E1don Jessen, Carol S. Mladinich, Carl L. Rich

\section{INTRODUCTION}

Sugar House Quadrangle in east-central Salt Lake County, Utah, has served as a test site for demonstrating applications of digital mapping technology to earthquake hazards reduction. The steep slopes of the Wasatch Range occupy approximately the eastern two-fifths of the of the quadrangle area. The nearly flat-lying western portion, site of rapid urban expansion in recent decades, is underlain by alluvial and lake deposits that are susceptible to high liquefaction and groundshaking hazards during earthquakes. The quadrangle also contains surface traces of north-south trending segments of the Wasatch Fault, likely sites of ground rupture during earthquakes.

Sugar House Quadrangle is noteworthy for its diversity of geologic, topographic, and land use features representative of the Wasatch Front earthquake hazard zone. These advantageous characteristics for a test site were recognized in the selection of the quadrangle as the site of a number of interdisciplinary studies and mapping efforts performed to demonstrate the applications of earth science information to land planning and management. Those studies resulted in the publication of the series of maps constituting the Sugar House Quadrangle Folio, Miscellaneous Geologic Investigation Maps I-766, A through 0, 1972-1977.

The Sugar House Quadrangle Folio contains basic information that pertains to several land management and hazard mitigation applications, information that includes surficial geology, slope, landslides and associated deposits, relative slope stability, construction materials, urban growth, thickness of saturated deposits, minimum depth to water in shallow aquifers, depth of bedrock, flood and surface water information, relative ages of faults, and inferred relative stability of the land surface during earthquakes.

This atlas has drawn heavily upon the materials of the Sugar House Quadrangle Folio, augmented by data from State and local government sources, from the National Mapping Division's digital map data bases, and from direct compilation and digitizing by members of the project team under Research Project RMMC 86-1.

Especially helpful have been detailed consultations with participants of the multi-agency National Earthquake Hazards Reduction Program, including those from the Geologic Division of the U.S. Geological Survey, the Federal Emergency Management Agency, the Utah Geological and Mineral Survey, and the Utah Division of Comprehensive Emergency Management.

The maps included here are illustrative of the kinds of information needed in earthquake hazards applications; many other kinds of information, and wider geographic coverage, would be needed in emergency management operations. The atlas is presented as a demonstration of how digital mapping and geographic information systems (GIS) technologies might in the future make those operations more effective and efficient. 


\section{Plate 1: Wasatch Front Earthquake Hazards Reduction Project}

The location of the Sugar House Quadrangle test site is indicated, in relation to the four counties -- Weber, Davis, Salt Lake, and Utah -which are the highest-priority counties for earthquake hazard reduction efforts, and which contain over 80 percent of the State's population. The approximate location of the surface trace of the Wasatch Fault is also indicated.

\section{USGS STANDARD DATA BASES}

Under this heading are the topographic map and derived digital data bases that are standard USGS products. The flexibility of the many display options for digital map data bases is illustrated by the selective and distinctively shaded presentations. Certain data bases were updated by manually digitizing from state and local government sources current in 1986.

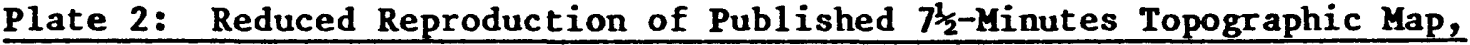
Sugar House Quadrangle, Utah

The stable-base mylar print of this map was used as a base map for plotting and digitizing the various data themes contained in this atlas. The most recent update of this map was from aerial photographs taken in 1975. The quadrangle is scheduled for revision in 1987-88.

\section{Plate 3: Boundaries and Public Land Survey System}

Computer-generated plots of boundaries and shading indicate political jurisdiction each of which will have certain responsibilities for emergency management and recovery before, during, and after damaging earthquakes. Map overlay software permits partitioning of other data bases according to these jurisdictions. The standard USGS digital line graph (DLG) data base was updated using 1986 data from local sources.

Plate 3 represents only a few of the many kinds of boundary information that might be useful in earthquake hazard reduction. Others include water districts, school districts, police and fire service areas, and utility service areas.

\section{Plate 4: Roads and Trails}

The standard DLG transportation categories include roads, trails, railroads, pipelines, and transmission lines. Such information is useful for geographic reference aids when using less-familiar earthquake hazard maps such as 1 iquefaction or groundshaking potential. Transportation facilities are also critical lifelines subject to disruption during earthquakes, and accuracte data bases are helpful in many aspects of disaster planning, response, and recovery. The themes "roads and trails" depicted in Plate 4 were selected from the standard DLG data base and manually updated to 1986. 
For simplicity, all road types are portrayed in plate 4 with a singleline symbol, whereas in the published topographic map some are represented cartographically by two parallel lines and other symbolization to identify different road types. For identifying conditions of roads during and after a disaster, many different attributes of the segments of a road network (e.g., type of street or highway, street name, type of road surface, state of repair, traffic carrying capacity) could be carried in the digital data base and plotted on command, along with measures of road lengths or plots of least-time paths through given segments of a road network.

\section{Plate 5: Digital Elevation Models}

Displayed in Plate 5 are computer graphics representations of the standard digital elevation model (DEM) data base for Sugar House Quadrangle. Different perspective views are shown to illustrate the capabilities of displaying digital topographic data as though the terrain surface were viewed from different compass directions, and different exaggerations of the vertical with respect to the horizontal dimensions. For example, without vertical exaggeration (A) a more realistic view, particularly of the mountains, is presented, but low-relief features are obscured. Vertical exaggeration (B) distorts the high-relief wasatch Range, but permits easier viewing of some of the more subtle terrain features such as the scarps along the Wasatch Fault and the benches formed at levels of ancient Lake Bonneville. Data on slope and aspect are used in a variety of assessments of earthquake hazards effects.

\section{GEOLOGIC AND HYDROLOGIC DATA}

Maps in this section are examples of geologic and hydrologic data bases which are useful in various phases of earthquake hazard assessment and mitigation. Data on landslides and floods are included because such phenomena can be induced by earthquakes and can greatly add to the damage and losses sustained.

\section{Plate 6: Surficial Geology}

Surficial geologic maps, properly interpreted and used in conjunction with other data, can aid in delimiting zones of differing degrees of expected ground stability during earthquakes. In Plate 6, a recentlycompleted surficial geologic map is shown, simplified by computer processing. The more detailed original map (also digitized, though not shown) has 23 categories, generalized to 7 for this presentation. A beneficial by-product of this digital map data base is a quicklyavailable computer-generated multicolor plot.

\section{Plate 7: Lands lides and Associated Deposits}

Landslides and mudflows from the recent geologic past may indicate zones of future potential damage from similar events that could be triggered by 
earthquakes. Also, in assessing land susceptibility to earthquake hazards, planners must consider other hazards as well; the population and land use data bases needed to calculate vulnerability are similar. For these reasons, maps of potential landslide and mudflow zones, such as those portrayed in Plate 7 , are included here among data bases recommended for earthquake hazard reduction.

Plate 8: Modified Hydrography

Al1 themes portrayed on this map except storm drainage pipelines and manmade open channels are typically contained in the standard USGS DLG data bases for $7 \frac{1}{2}$-minute quadrangles. Storm drainage pipeline and man-made open channel data were obtained from local sources and digitized manually into the data base. The DLG data for the Sugar House Quadrangle were input to the data base directly from computer-compatible tapes, then manually updated where data for doing so were available. Since for earthquake planning and response it is sometimes helpful to consider all hydrographic factors together, the various hydrographic themes were combined in one presentation for this plate. These and other map themes can, if desired, be displayed separately or in any combinations.

\section{Plate 9: Liquefaction Potential}

The potential for ground failure due to liquefaction is mapped in Plate 9. As a result of liquefaction, buildings, roads, and other structures may settle, tilt, collapse, or otherwise fail. of the four degrees of severity mapped for the most vulnerable areas of the Wasatch Front -- high, moderate, low, and very low -- all except low are present in the area of the Sugar House Quadrangle. Computer calculations performed after digitizing and input of the map unit boundaries revealed that $14.2 \mathrm{~km}^{2}(3,497$ acres), or 9.7 percent of the quadrangle area falls in the high liquefaction potential category; another 17 percent is subject to moderate liquefaction potential.

\section{Plate 10: Relative Land Surface Stability During Barthquakes}

Maps depicting geographic variation in relative groundshaking expected or predicted during earthquakes are being prepared for the Wasatch Front region by USGS scientists working under the National Earthquake Hazards Reduction Program. Such maps are useful, when used in conjunction with other data, in calculating expected losses to buildings and other structures.

Since the new USGS maps were not available in time for inclusion in this atlas, an older map, published in the Sugar House Quadrangle Folio in 1977 , is included as Plate 10. Data from a variety of sources -geologic, geophysical, hydrologic, historic -- were used.

Plate 11: 100- and 500-Year Flood Zones

FEMA flood insurance maps can be useful in determining areas of potential flooding resulting from earthquake-induced dam failure, or from other 
hydrologic anomalies. Such maps for the area of Sugar House Quadrangle were recompiled on the $1: 24,000-$ scale base map and digitized for inclusion in the project data base. The resulting computer-generated plot is shown as Plate 11 .

\section{GEOGRAPHIC DATA}

Maps in this section contain examples of various geographic data coverages that are useful for earthquake planning, response, and recovery. These coverages include critical facilities and lifelines that are the foci of response and recovery operations. Also included are the census geographic units which make possible the linking of data on population and housing to specific geographic areas or zones.

\section{Plate 12: Selected Lifelines}

Damage to lifelines -- those critical facilities for transporting and delivering people, water, fuels, waste, electrical energy, information, and other commodities necessary for the functioning of a modern economy -- can be very disruptive during the response and recovery phases following an earthquake. Therefore, lifeline data bases are important in planning to minimize earthquake losses. Plate 12 illustrates the distributions of two such lifelines, watermains and primary natural gas lines.

\section{Plate 13: Selected Critical and Response Facilities}

The location, functions, and capacities of facilities that will be critical to the response planning for a major earthquake are important factors for an emergency management data base. These facilities may be used, for example, as command centers and as temporary shelters. Schools, fire stations, medical facilities, and law enforcement stations, depicted in Plate 13, are only a few of the many critical and response facilities.

Plate 14: Census Tracts, 1980

Census tracts are the principal data units for assigning information from the census of population and housing to geographic areas within a metropolitan region. Tract boundaries were replotted from Census Bureau maps to the USGS quadrangle base, permitting geographic association of census data with hazard zones and response facilities. Tracts 1034 and 1109 were selected to illustrate types of census data useful for earthquake hazard planning, and geographic variation in population and housing characteristics. Examples of such characteristics are total population, numbers in very young and very old age categories, age of residence, and type of fuel used for heating. 
Plate 15 was compiled to illustrate the possibility of employing census data to define geographic units smaller than tracts. Tract 1034 is subdivided into block groups and individual blocks. In urban areas where the census bureaus DIME files are available and updated, further geographic breakdown to street address ranges is possible. The more detailed geographic units are helpful in matching population and housing characteristics with hazard zones. Eventually, through collaboration now taking place between USGS and Census Bureau, the data bases of the two agencies will be geographically more compatible.

\section{Plate 16: Land Use and Land Cover, 1986}

Applications of land-use data bases to earthquake hazard analysis include quick delineation of built up areas where major concentrations of people, industries, and critical facilities are located. Land-use maps are also useful for planning future developments and monitoring compliance with hazard zonation. Land-use data bases were compiled for this project using 1981 and 1986 aerial photography. The standard USGS land use/land cover classification scheme was employed.

\section{ANALYSIS EXAMPLES}

This section includes examples of computer-aided analysis that can be performed by extracting, combining, measuring, or otherwise comparing data from the various project data bases. The users can pose questions to the analysts who mediate between user and data base at the present early stage of adoption of the GIS technology. Later the users may "own" their analysis capability. The types of analysis demonstrated here are selected from a much larger set of data base manipulations that are possible with current GIS software and hardware. The examples were chosen to reflect needs and interests of users with specific earthquake hazard problems to solve, and/or users with specific responsibilities in earthquake hazard mitigation. However, not all of the types of analyses needed by such users are illustrated here, and future analytical capability may be driven by users' responses to demonstrations of system capabilities.

\section{Plate 17: Land Surface Slopes}

A slope map can be automatically produced, given appropriate software, from the DEM data base. Since a pre-existing slope map was available for Sugar House Quadrangle (from the Sugar House folio maps), that map was digitized and used as a demonstration product. Data on slopes are used in delineation of landslide, avalanche, and liquefaction potential hazard zones.

Plate 18: Zone of Potential Surface Rupture Associated with Fault Trace

GIS software was used to calculate a 600-foot buffer zone surrounding the Wasatch fault trace. Such a zone is estimated by Utah geologists to be 
subject to surface rupture during earthquakes; however, the zone designated in Plate 18 is primarily for demonstration of the computer buffering capability, not for specific site evaluation. Since the fault dips to the west, the buffer zone is asymmetric with respect to the fault trace (500-foot offset to the west and 100-foot offset to the east).

\section{Plate 19: Lifelines in Potential Surface Rupture Zone}

Plate 19 was produced by overlaying two data bases: 1ifelines (P1ate 12) and potential surface rupture zone (Plate 18 ). The technique is used to highlight areas where the lifelines are particularly vulnerable to the hazard of surface rupture. The system also calculates total length of pipelines in the surface rupture zone.

\section{Plate 20: Schools and Residential Areas in High Liquefaction Potential Zones}

Potential vulnerability of schools and residences to liquefaction hazards is illustrated by selecting themes from the critical and response facilities map ( $P$ late 13), land use (Plate 16), and liquefaction (Plate 9). Residential and critical facilities outside the high liquefaction zone are excluded from this plot. Counts and area measurements are also available.

Plate 21: Schools and Residential Areas on Land Surfaces with Lowest Stability During Earthquakes

The data bases from land use ( $\mathrm{Plate} 16$ ), and from critical and response facilities (Plate 13), were combined with the data base on land with lowest predicted stability during earthquakes (Plate 10).

Plate 22: Areas of Land Use Change, 1981-1986, Land Use in 1981

Areas of land use change from 1981 to 1986 were mapped by comparing the 1981 map (precursor to Plate 16) with 1986 aerial photography. In Plate 22 the areas of change are coded to indicate land use before the change (1981).

Plate 23: Areas of Land Use Change, 1981-1986, Land Use in 1986

Areas of 1 and use change from 1981 to 1986 were mapped by comparing the 1981 map with 1986 aerial photography. In Plate 23 the areas of change are coded to indicate 1 and use after the change (1986). Graphic display and area calculations for such maps are greatly facilitated by the use of digital mapping and GIS. When compared with geologic and hydrologic data bases, maps such as those of Plates 22 and 23 can indicate either increase or decrease in vulnerability of new facilities to geologic and hydrologic hazards. 


\section{P1ate 24: Undeveloped Land (1986) Not in Major Geologic Hazard Zones}

Computer data bases on potential surface rupture zones, high liquefaction potential zones, least stable land during earthquakes, landslides, mud flows, flash floods, and steep slopes were automatically compared with land use still undeveloped in 1986. The remainder (the shaded areas) indicates undeveloped land still remaining outside a major hazard zone. Such maps can be useful in the land use planning process.

P1ate 25: Undeveloped Land in 1981 Classified as Developed in 1986

Plate 25 illustrates another of the many choices for display of land use change data drawn from a digital map data base. This plate shows all land in an undeveloped category in 1981 which had changed into a developed category in 1986. If obtained in a timely basis, such maps can be useful in indicating to planners the general pattern of development. The pattern of growth might also be used to predict locations of future growth.

Plate 26: Urban Growth, 1890-1986

The graph in Plate 26 depicts the development history of Sugar House Quadrangle over a period of almost 100 years. The major geographic constraint to such development has been the steep slopes of the Wasatch Range in the eastern portion of the quadrangle. Pre-1981 data were obtained by Richard Van Horn and published in the Sugar House Quadrangle Folio. 1981 and 1986 data were obtained from this project (Plates 16 and 23).

\section{P1ate 27: Growth of Built-up Land, 1890-1986, Incremental}

Plate 27 displays spatial patterns of incremental development growth for each period of change plotted in the graph, Plate 26. Post-1969 growth took place primarily as infilling and as the extension of small subdivisions eastward toward the Wasatch Range slopes.

Plate 28: Growth of Built-up Land, 1890-1986, Cumulative

Plate 28 displays spatial patters of cumulative development growth for each period of change plotted in the graph, Plate 26. The illustrations of Plates 26, 27, and 28 may be useful to convey the possibilities of appropriate earthquake hazard planning in other quadrangles where the development has not proceeded as far toward the limits of geologic constraints as that in the Sugar House Quadrangle.

\section{IMPLEMENTATION}

Implementation of earthquake hazard reduction involves translation of the scientific conclusions into actions which reduce the region's vulnerability to future earthquakes. Among the major tasks of implementing earthquake 
hazard reduction will be the organization, management, and communication of a body of information that is essential for wise decisions and actions. Pre-earthquake planning for safe reconstruction following the disaster is also a function of implementation. Information and its effective communication are required not only to describe the environmental and economic conditions at a given time, but also to take account of changes, such as population growth and regional development, that are affecting the future vulnerability of the region. This concluding section of the atlas contains some options and suggested steps that can be taken to apply GIS capability and coordinated digital data bases to the implementation process.

\section{Plate 29: Implementing Earthquake Loss Reduction}

Plate 29 contains summaries of results and recommendations that were presented in workshops and other presentations of project results. Though some of the results and recommendations pertain to support of earth science research, most pertain to the role of information systems in implementing long-term earthquake loss reduction measures.

Plate 30: Diagrammatic Relationship of Land Ownership Parcels and Other Data Bases

A long-term goal for implementing earthquake hazard information systems is the eventual linking of data bases at the land parcel level with data bases at the quadrangle and smaller-scaled map levels. This illustration was prepared to illustrate such relationships. Block 208 is at the southeastern corner of Block Group 2, Census Tract 1034, Sugar House Quadrangle. Land parcel data on file in the Salt Lake City Planning Department were obtained for the ownership parcels in Block 208, plotted and shaded by land use category. Coordination of local government records, in a digital map data base, could provide access to such data categories as building age, number of stories, type of construction, valuation, and other data contained in building permit and tax assessment records. The location of the fault rupture zone is only for purposes of illustration; the original data used to portray the fault zone are not detailed enough for accurate representation at a map of this scale. Similarly, the location of the water mains and primary natural gas mains are derived from data entered on smaller scale maps, and do not necessarily represent accurate location with respect to the land parcels depicted. 


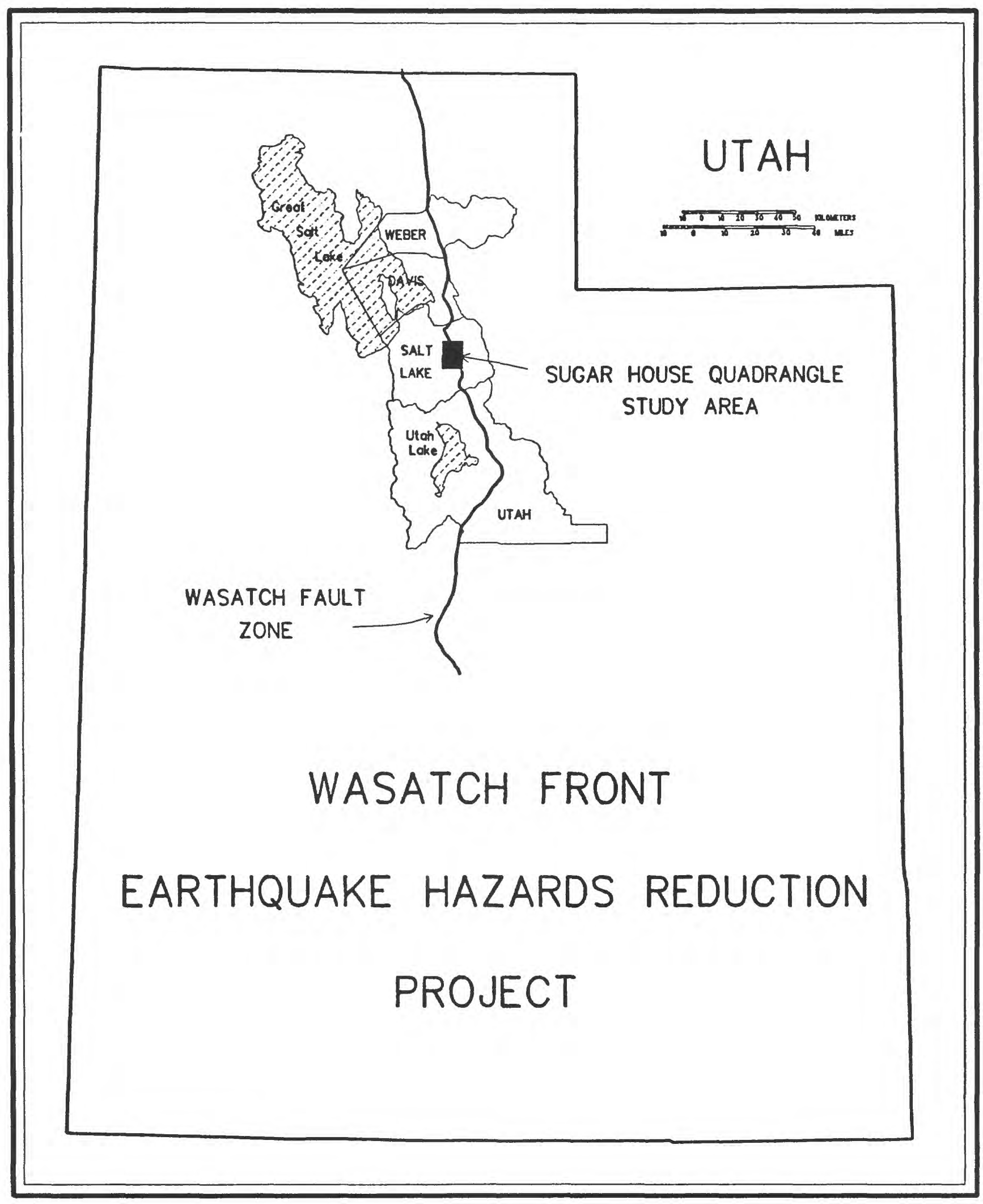


USGS STANDARD DATA BASES 
PLATE 2

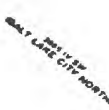

UNITED STATES

DEPARTMENT OF THE INTERIOR

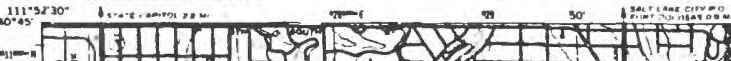

H 140

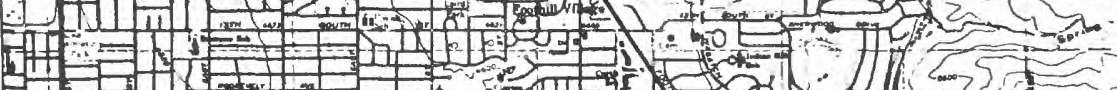

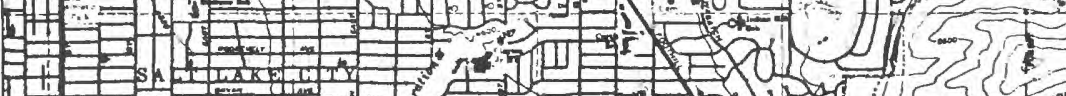

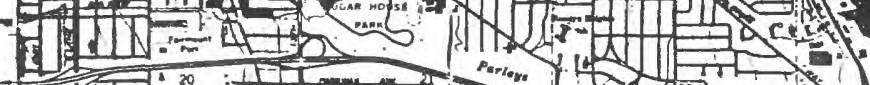

III

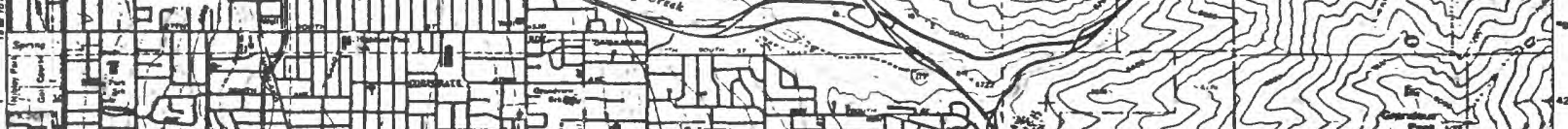

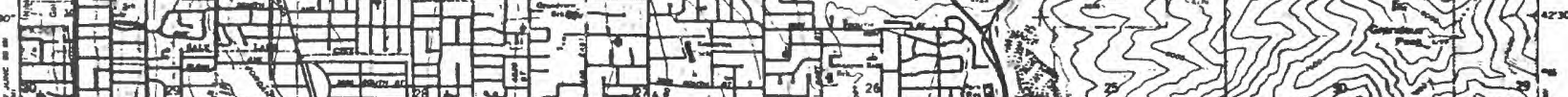

1.

II 3 -

- $f$ :

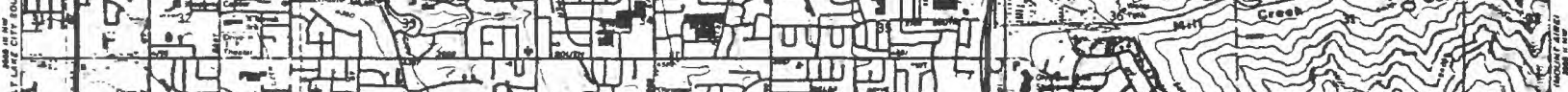

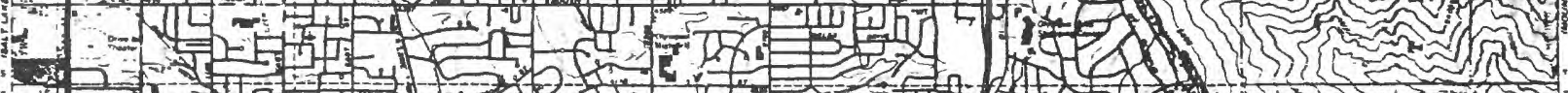
13

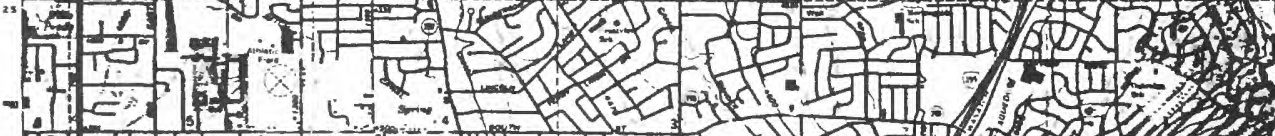

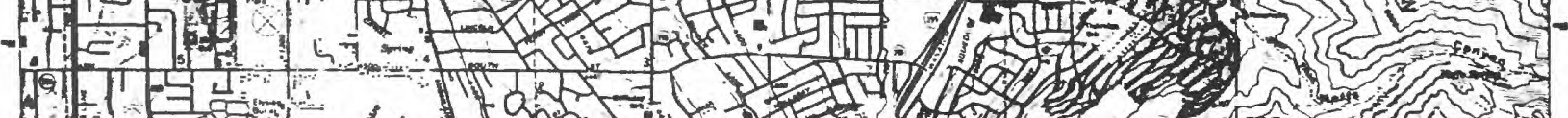

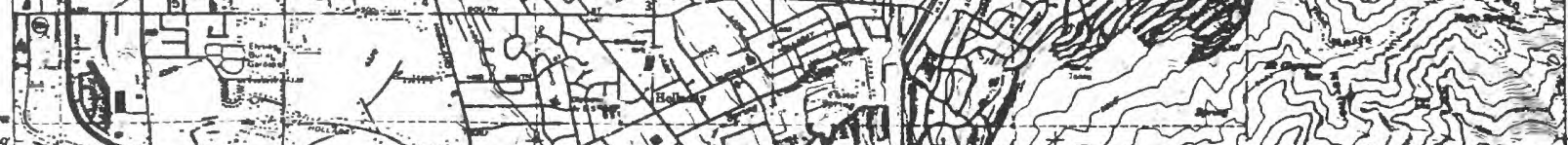

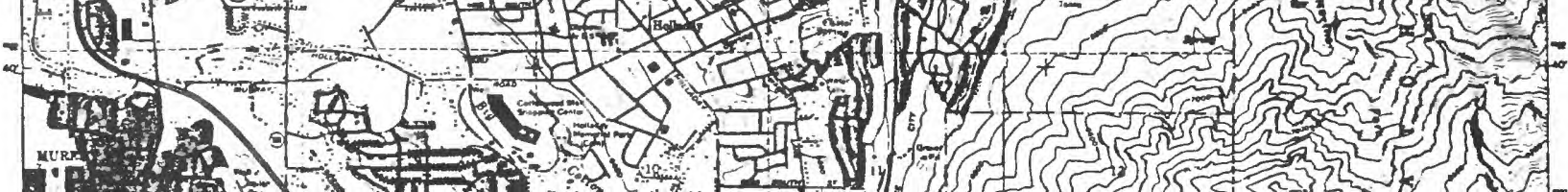

2 .

(n)

If

$4=1$.

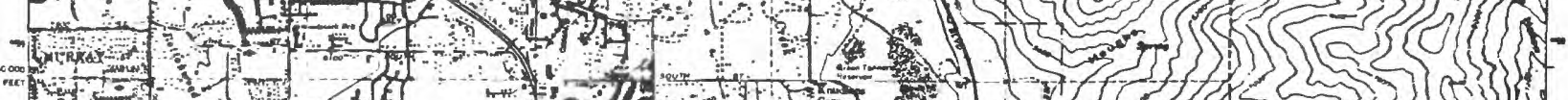

(1)
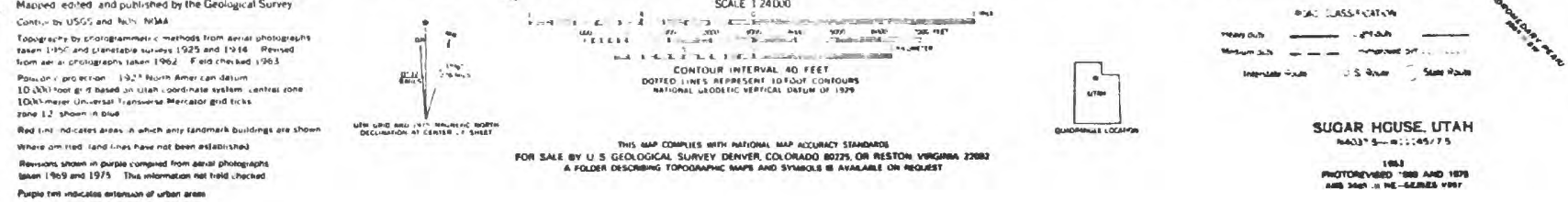

rament = 


\section{BOUNDARIES AND PUBLIC LAND SURVEY SUGAR HOUSE QUADRANGLE, UTAH}

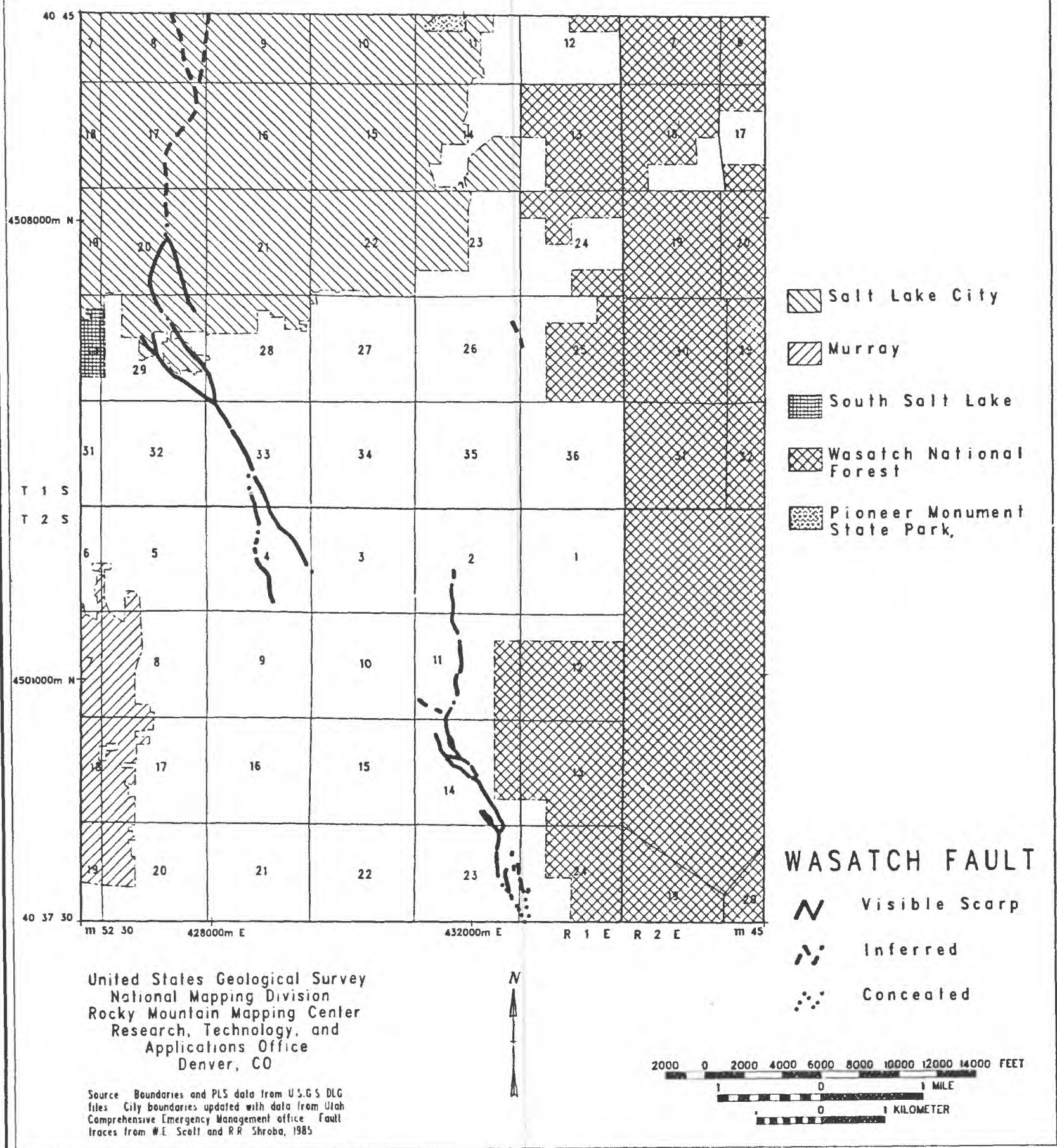




\section{ROADS AND TRAILS SUGAR HOUSE QUADRANGLE, UTAH}

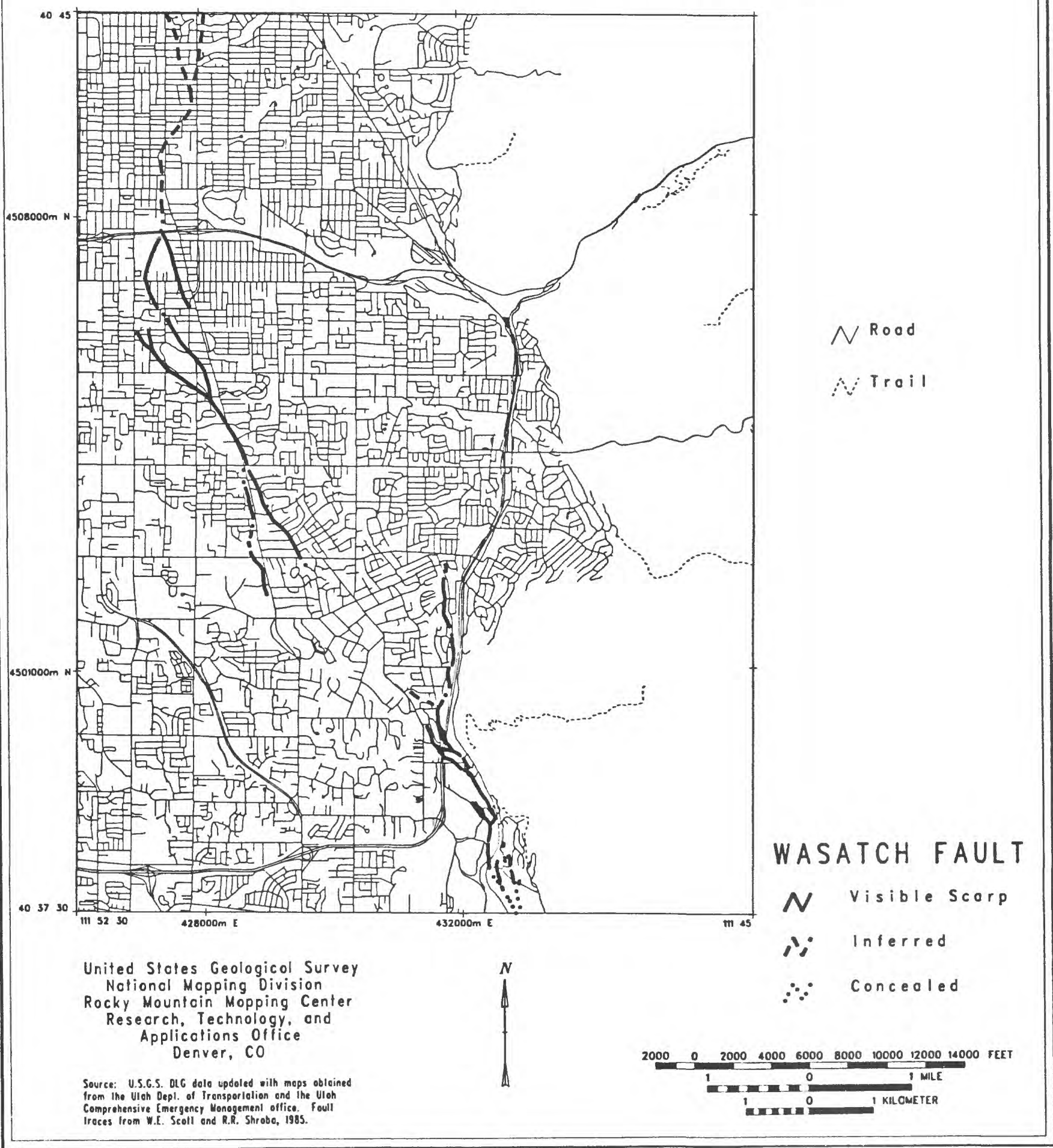


DIGITAZ ELEJATIOH MODEE A

\section{SUGAR HOUSE QUADRANGLE, UTAH}

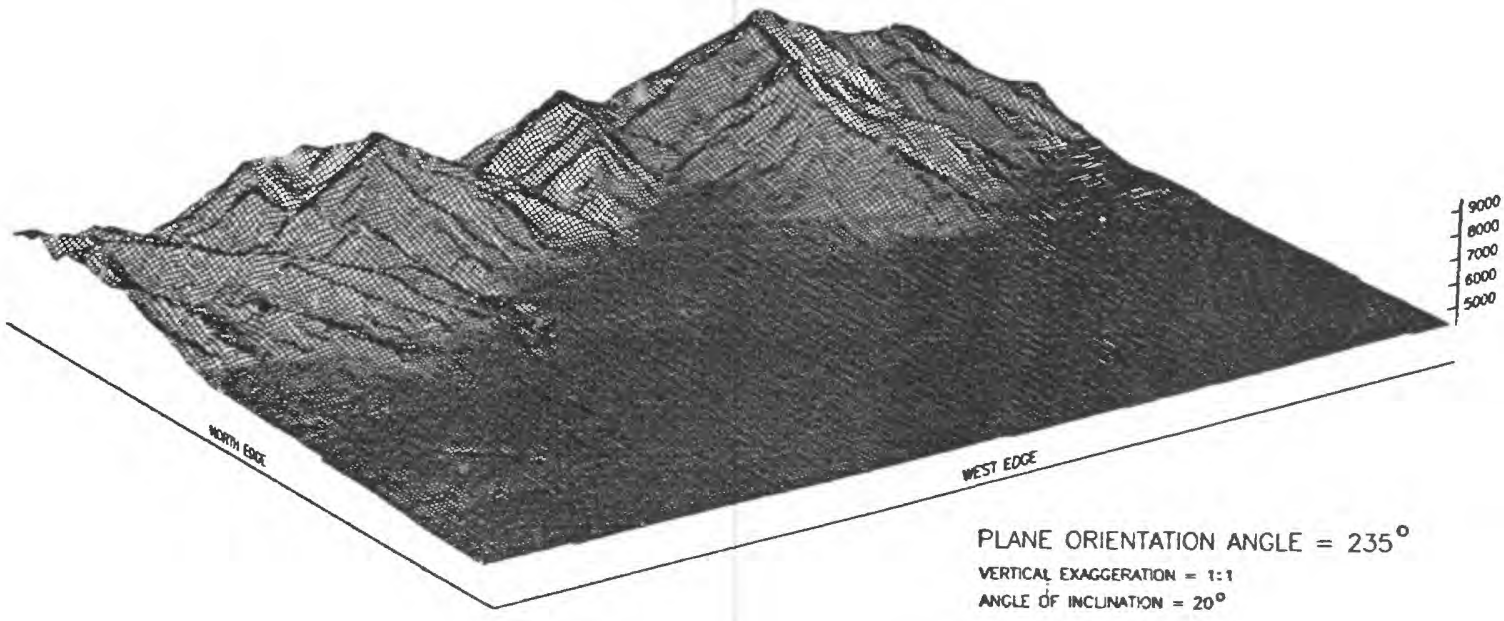

DIGITAL ELEVATION MODEL 3

SUGAR HOUSE QUADRANGLE, UTAH

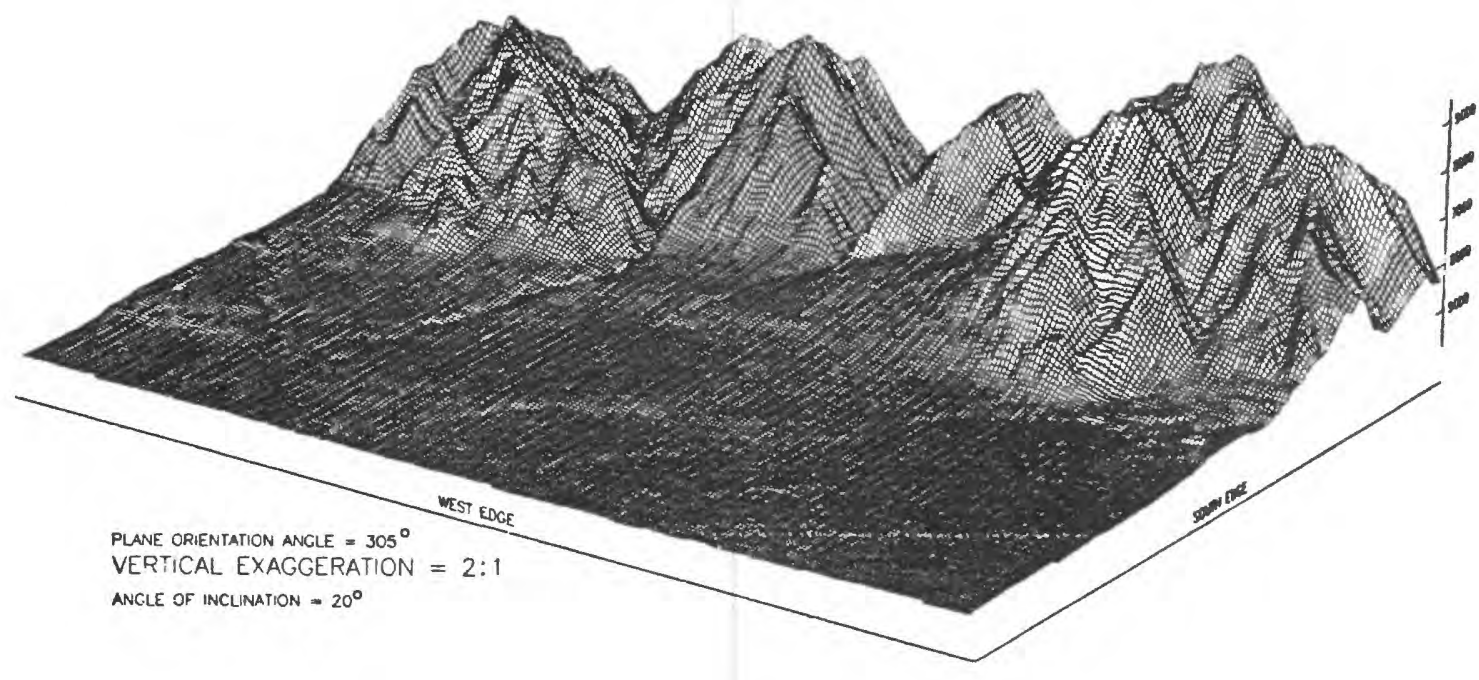


GEOLOGIC AND HYDROLOGIC DATA 


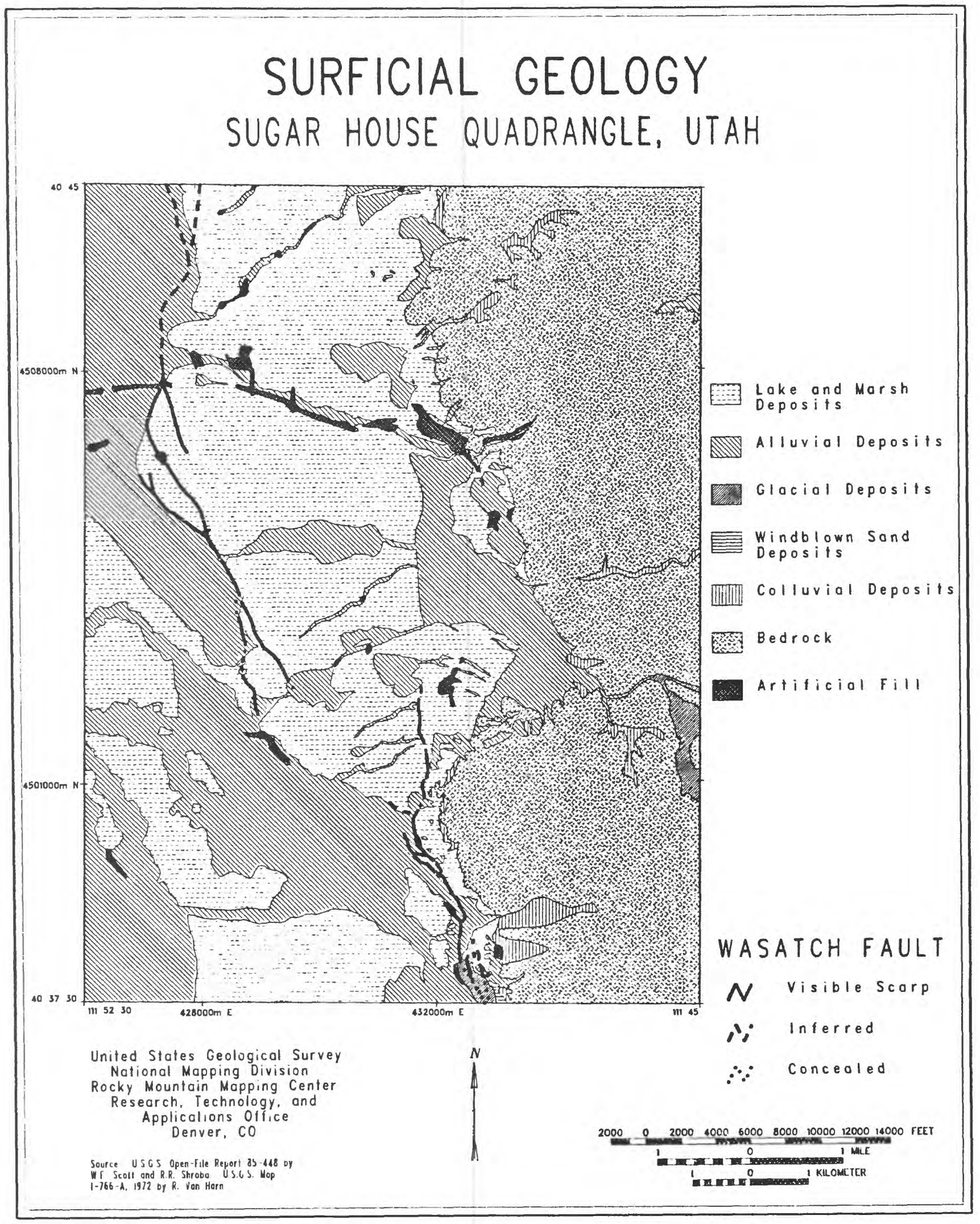




\section{LANDSLIDES AND ASSOCIATED DEPOSITS SUGAR HOUSE QUADRANGLE, UTAH}

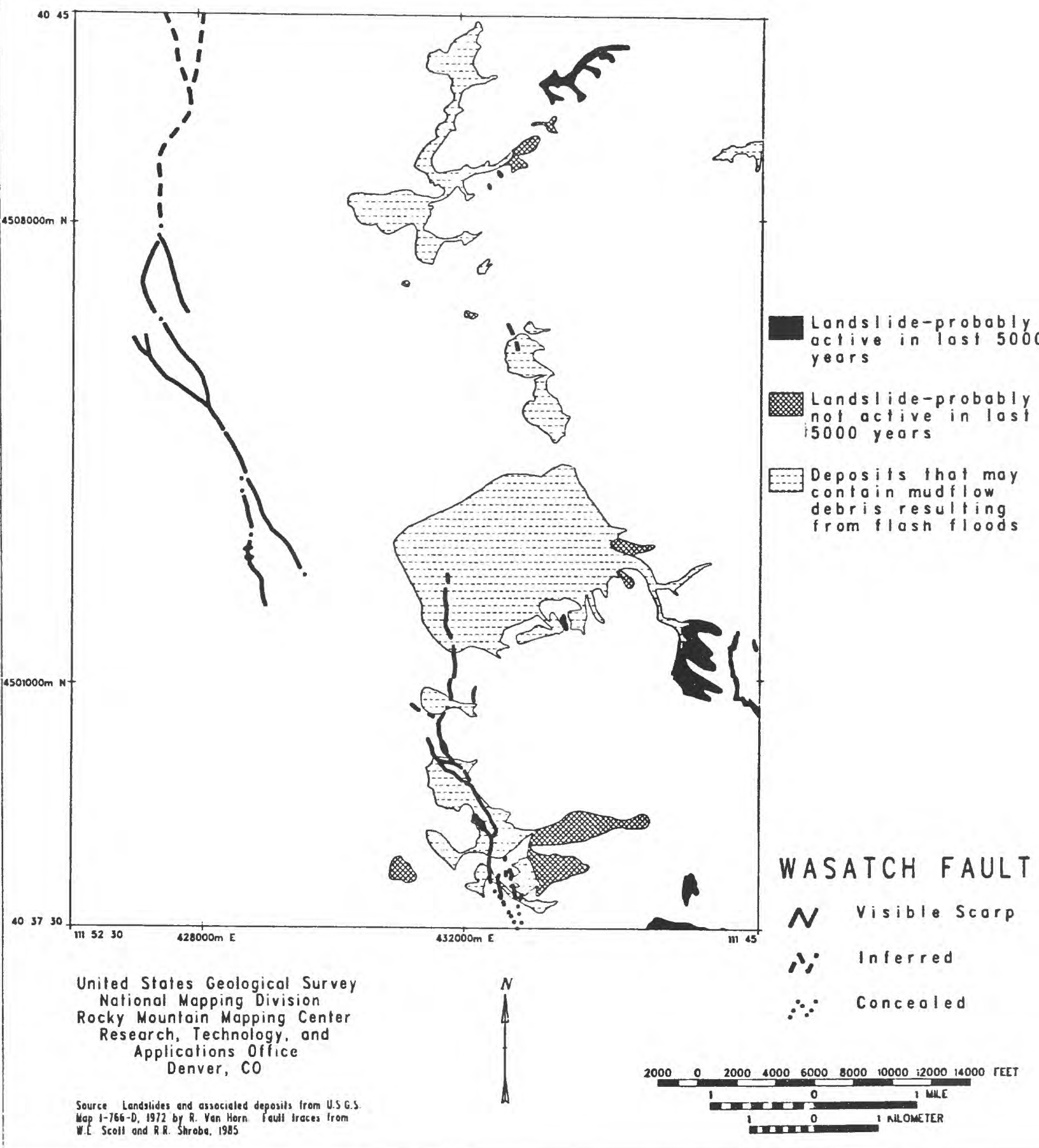




\section{MODIFIED HYDROGRAPHY SUGAR HOUSE QUADRANGLE, UTAH}

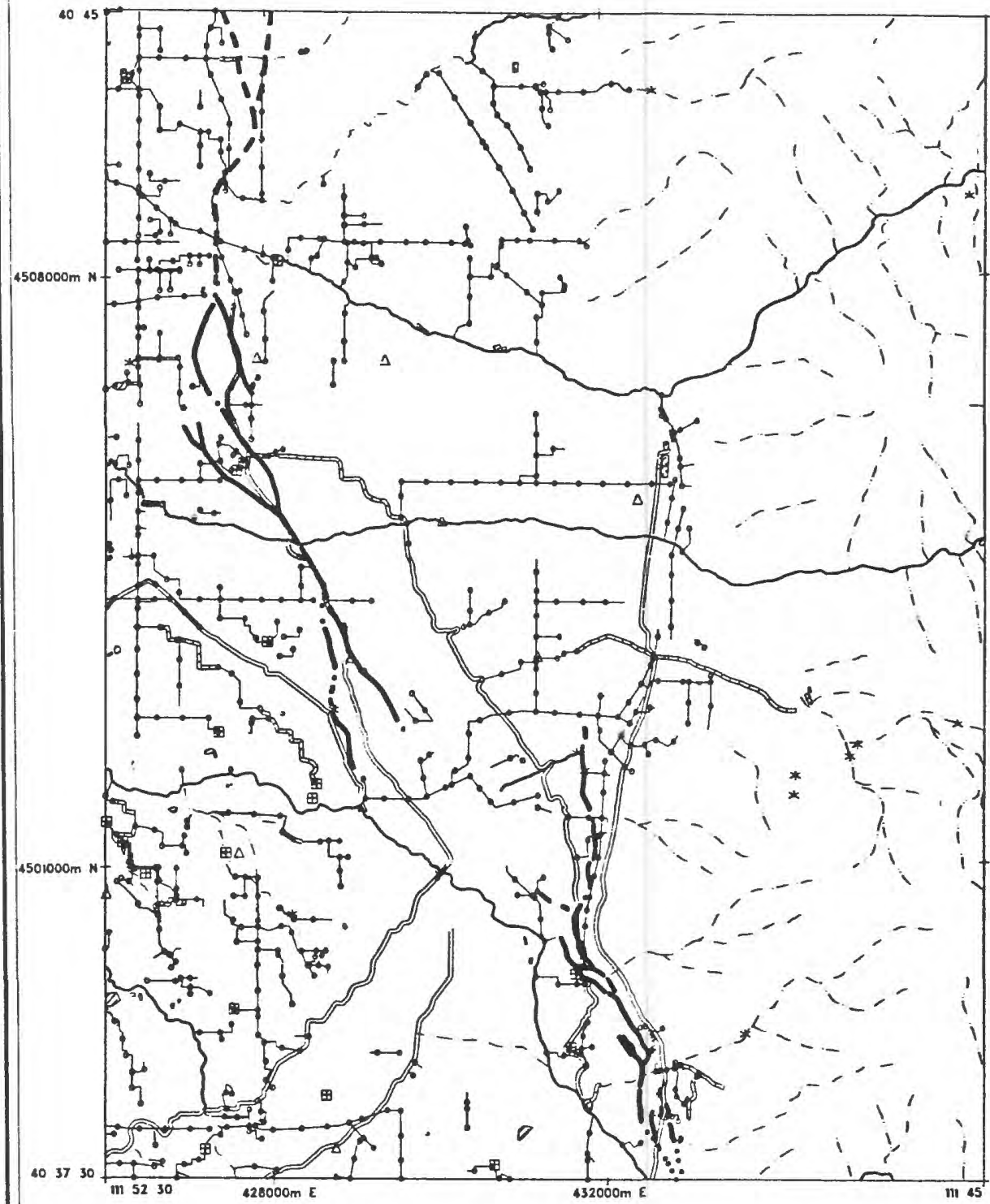

Uniled Slates Geological Survey National Mopping Division Rocky Mountain Mopping Center Reseorch. Technology, and Applications Office Denver, $\mathrm{CO}$

Source U.S CS. DLC dolo with addil. onal dais taken Irom Salt Lake Couniy Dept of Public Woriks map. Sepl 1985 Foult iraces liom af Scott and $P$. She abe, 1985

NPerennial stream

ci) Intermittent st reom

$\mathbb{N}$ canol or aqueduct

N Storm drainage pipeline

W Man-made open channel

DIT Lake or pond

Reservoir

rat Covered reservoir IIIIn] $F$ ish halchery

* Spring

$\triangle$ Non-flowing well

- Delention basin

WASATCH FAULT N Visible scarp

in Inferred

$\therefore \quad$ Concealed 


\section{LIQUEFACTION POTENTIAL SUGAR HOUSE QUADRANGLE, UTAH}

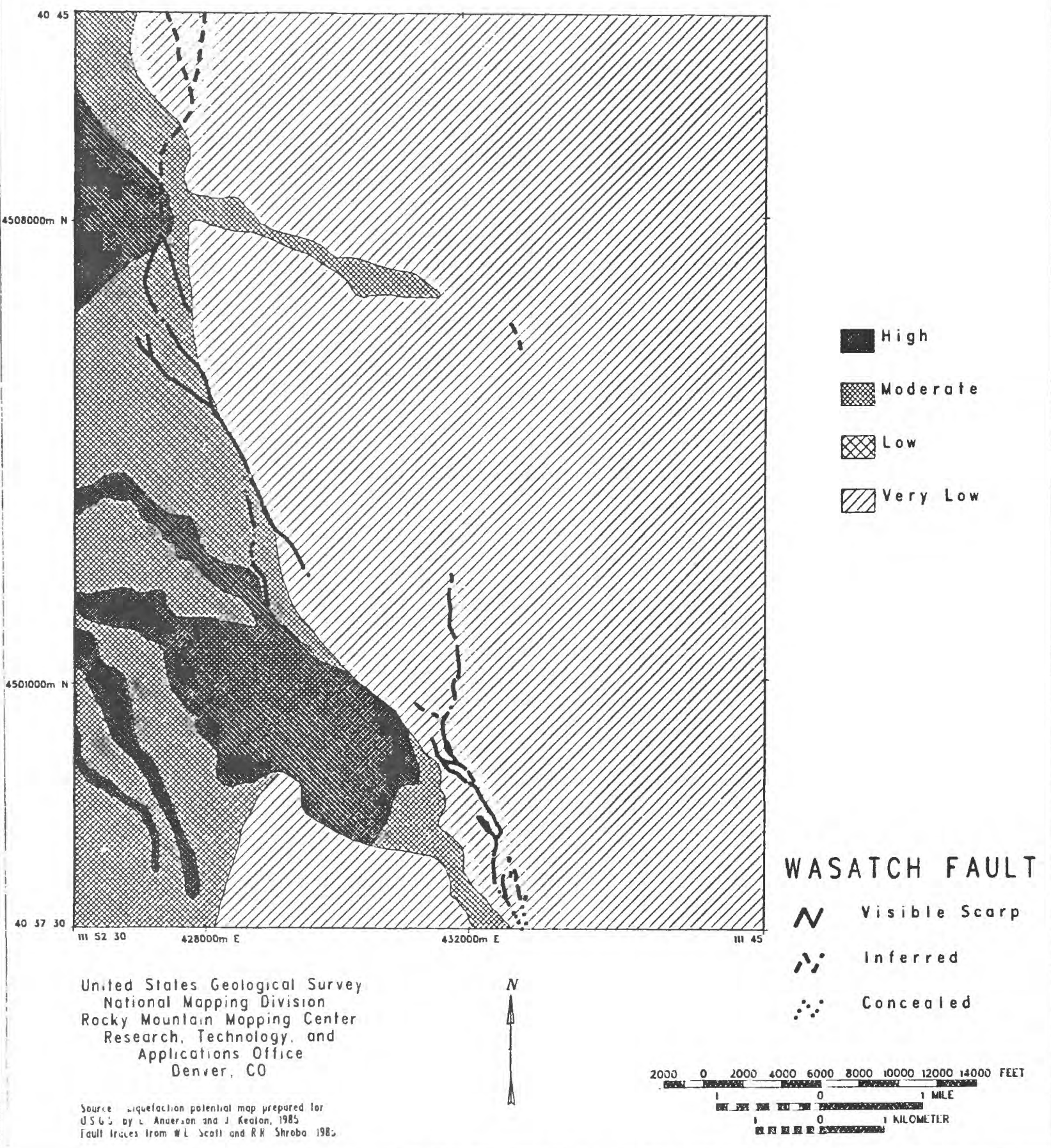




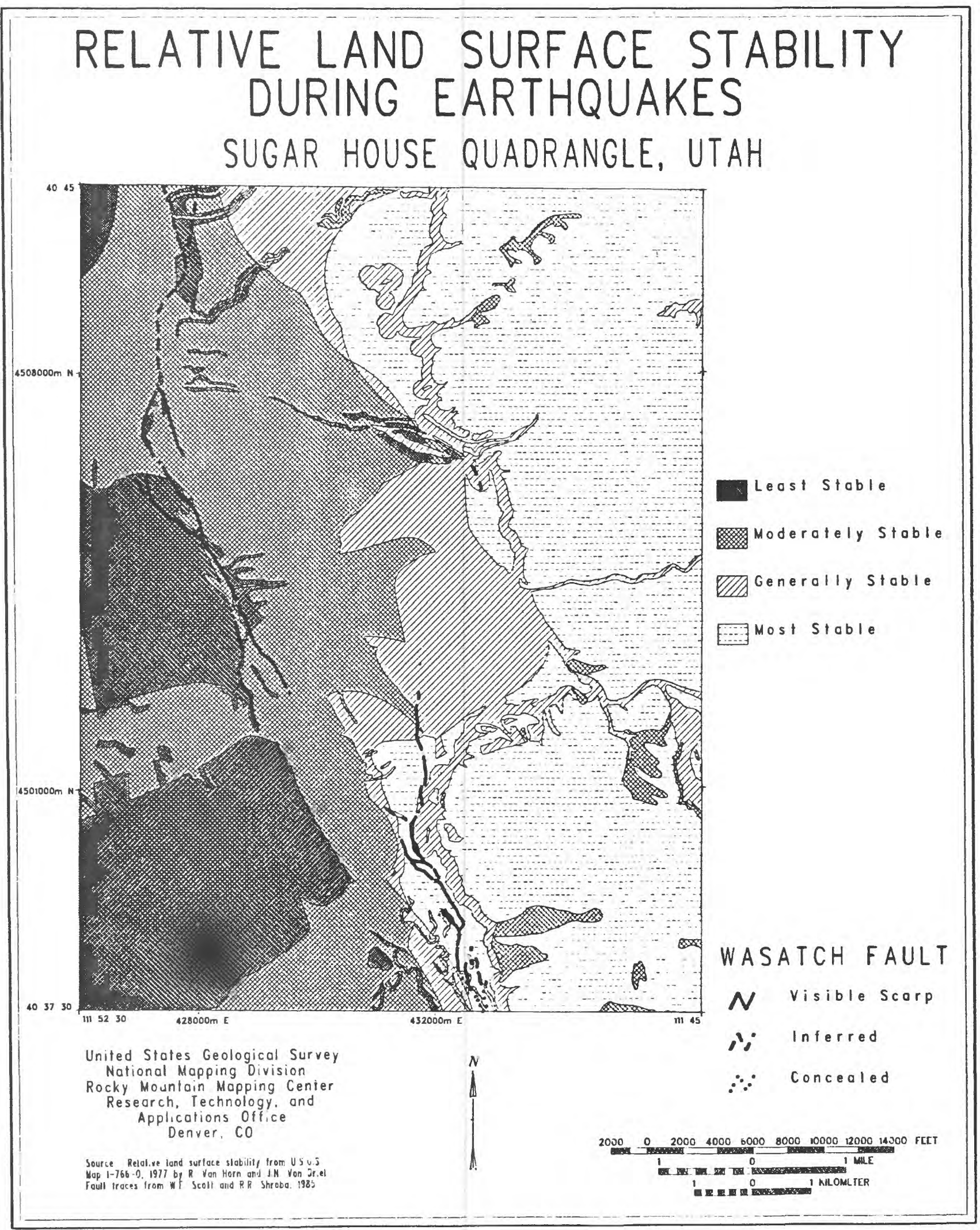




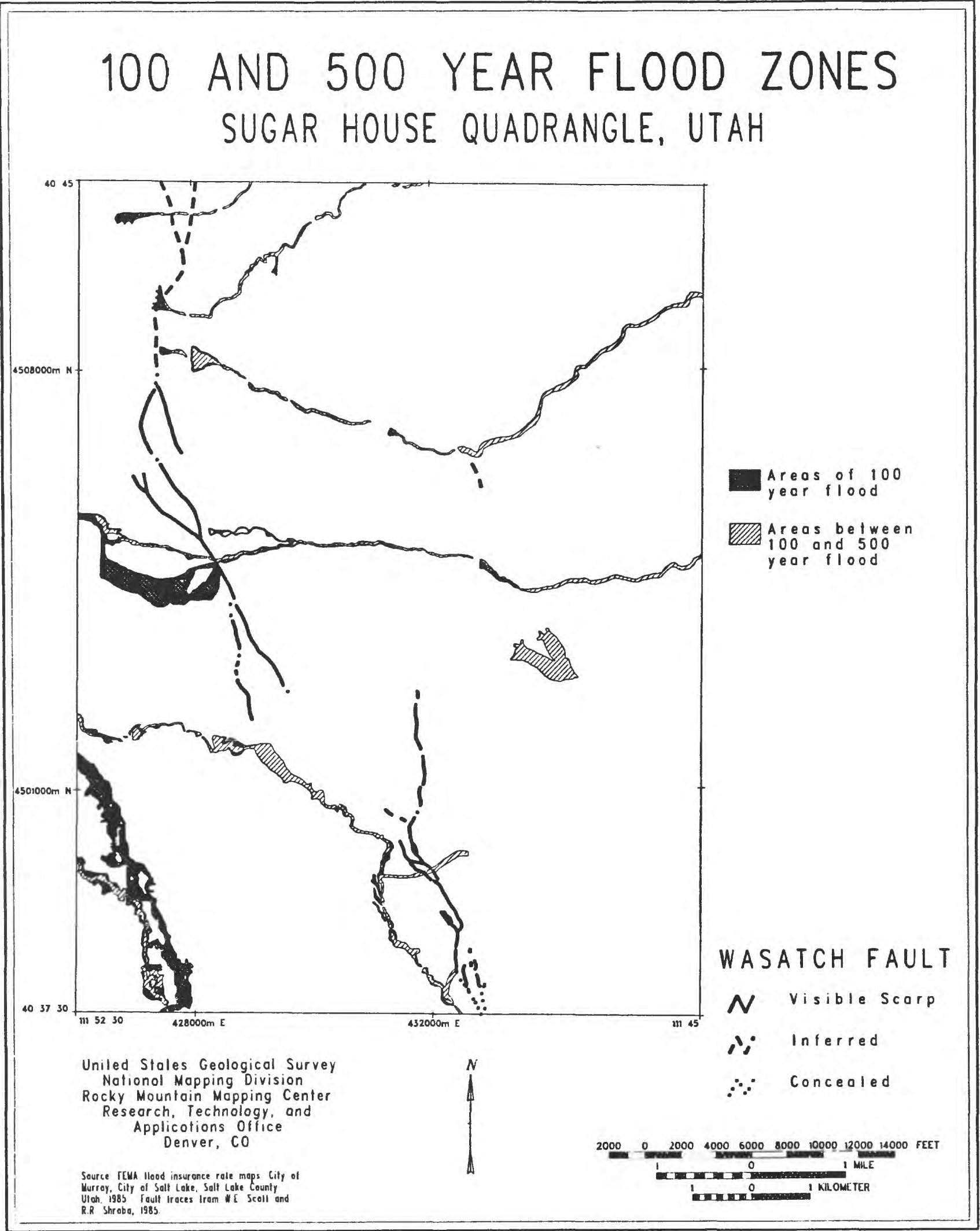


GEOGRAPHIC DATA 


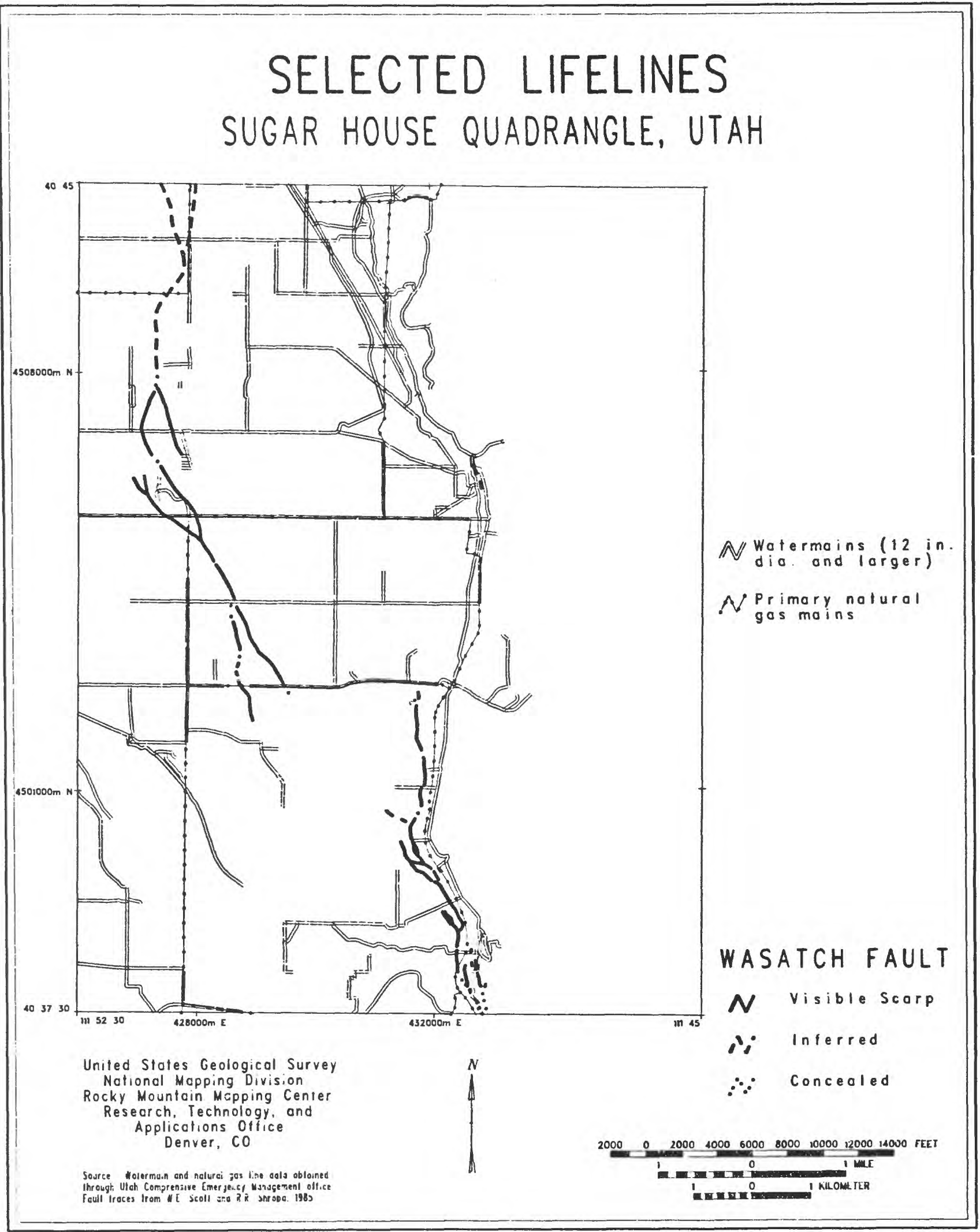




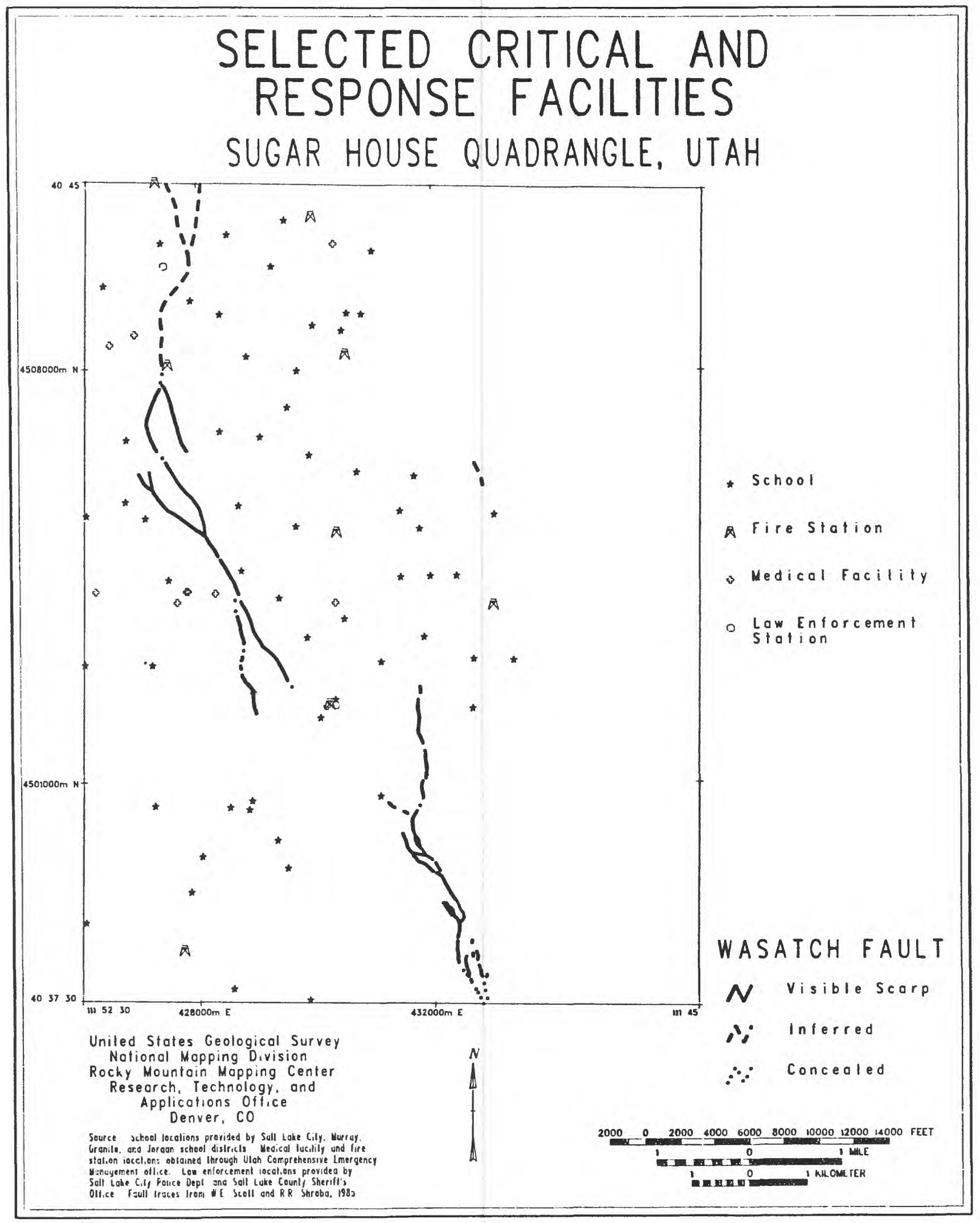




\section{CENSUS TRACTS, 1980 SUGAR HOUSE QUADRANGLE, UTAH}

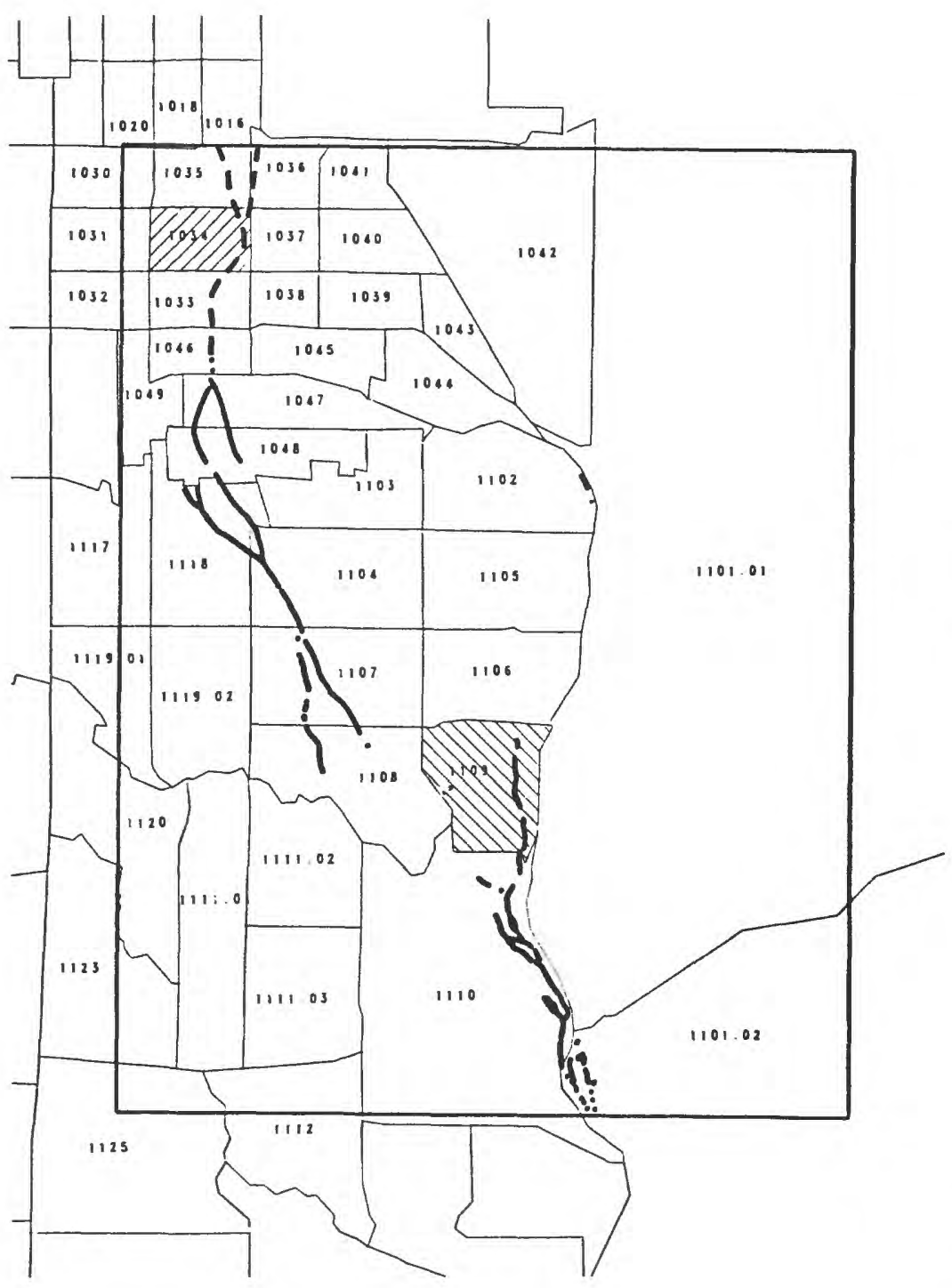

Uniled States Geological Survey National Mapping Division Rocky Mounlain Mopping Center Research, Technology, and Applications office Denver, CO

Soustce U5. Bureou of the Census 1980 census lrout acto. 1982 Foull lioces from WE Seoll and 18 jhrobe, 1983
Q7 Sample Troct 1

IIV Somple Tract 2
WASATCH FAULT

$N$ visible scorp

$\therefore$ Inferped

$\therefore$ Concealed 


\section{CENSUS GEOGRAPHICAL UNITS}

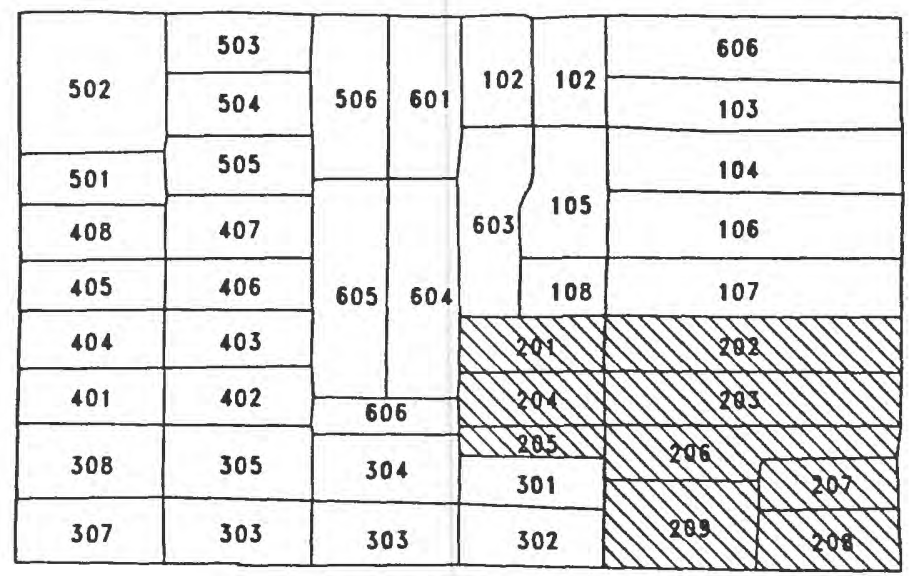

CENSUS TRACT 1034

BLOGK GROUP 2

\begin{tabular}{|l|l|}
\hline 201 & 202 \\
\hline 204 & 203 \\
\hline 205 & 206 \\
\cline { 1 - 2 } & 209 \\
\cline { 2 - 3 } & 207 \\
\hline
\end{tabular}

BLOCK 208

United States Geological Survey

National Mapping Division

Rocky Mountoin Mopping Center

Research. Technology, and

Applications Office

Denver, $\mathrm{CO}$ 


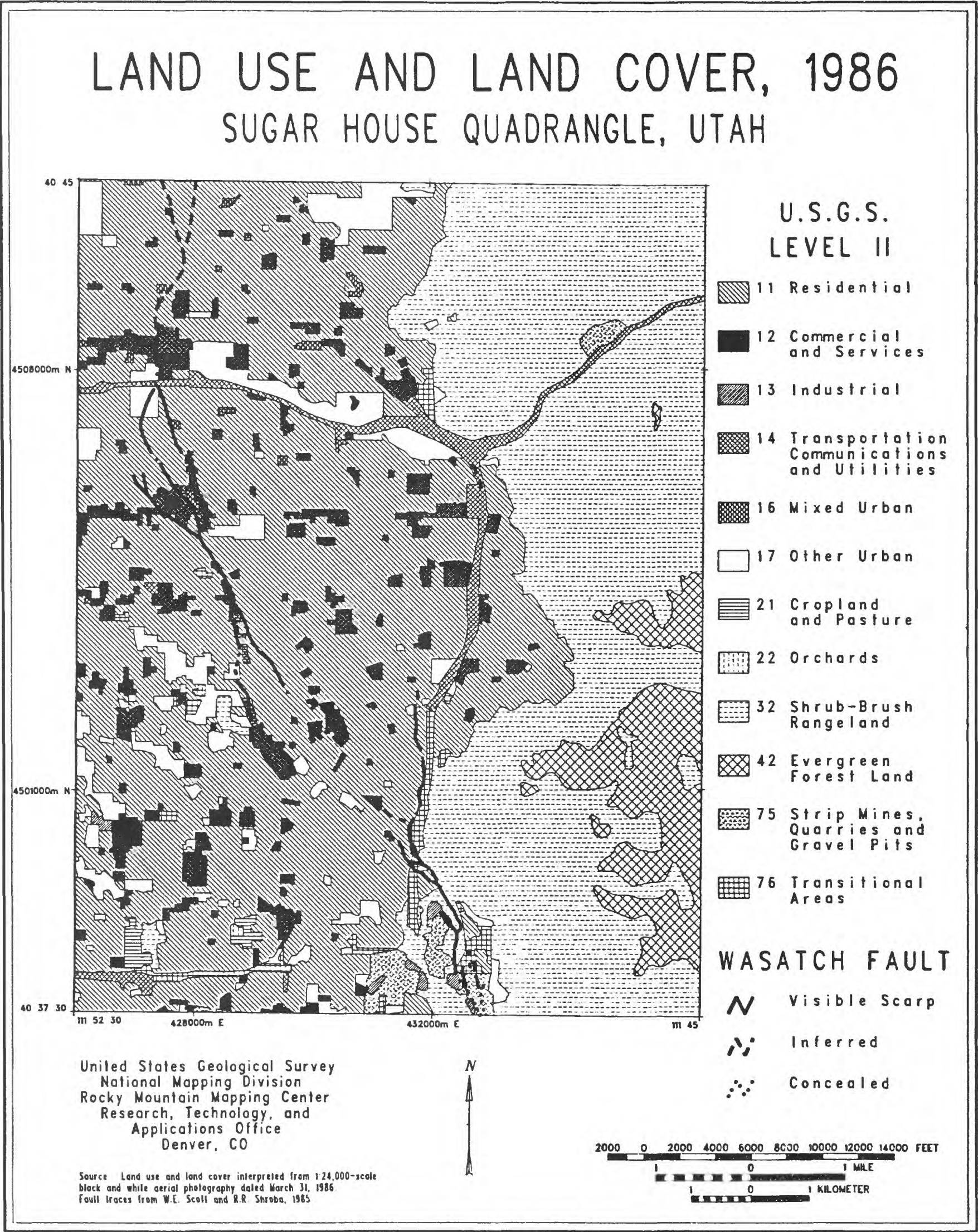


ANALYSIS RXAMPLES 


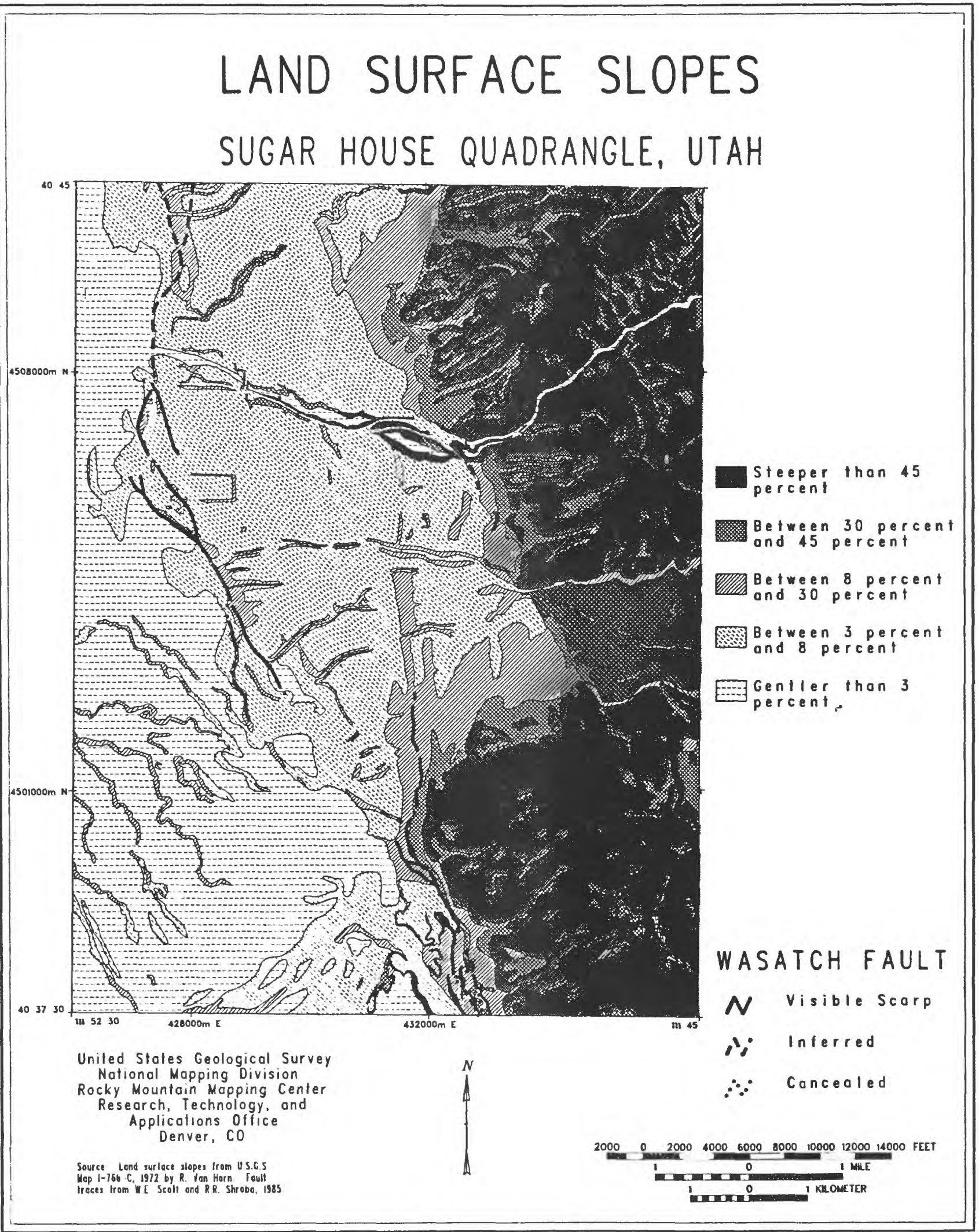




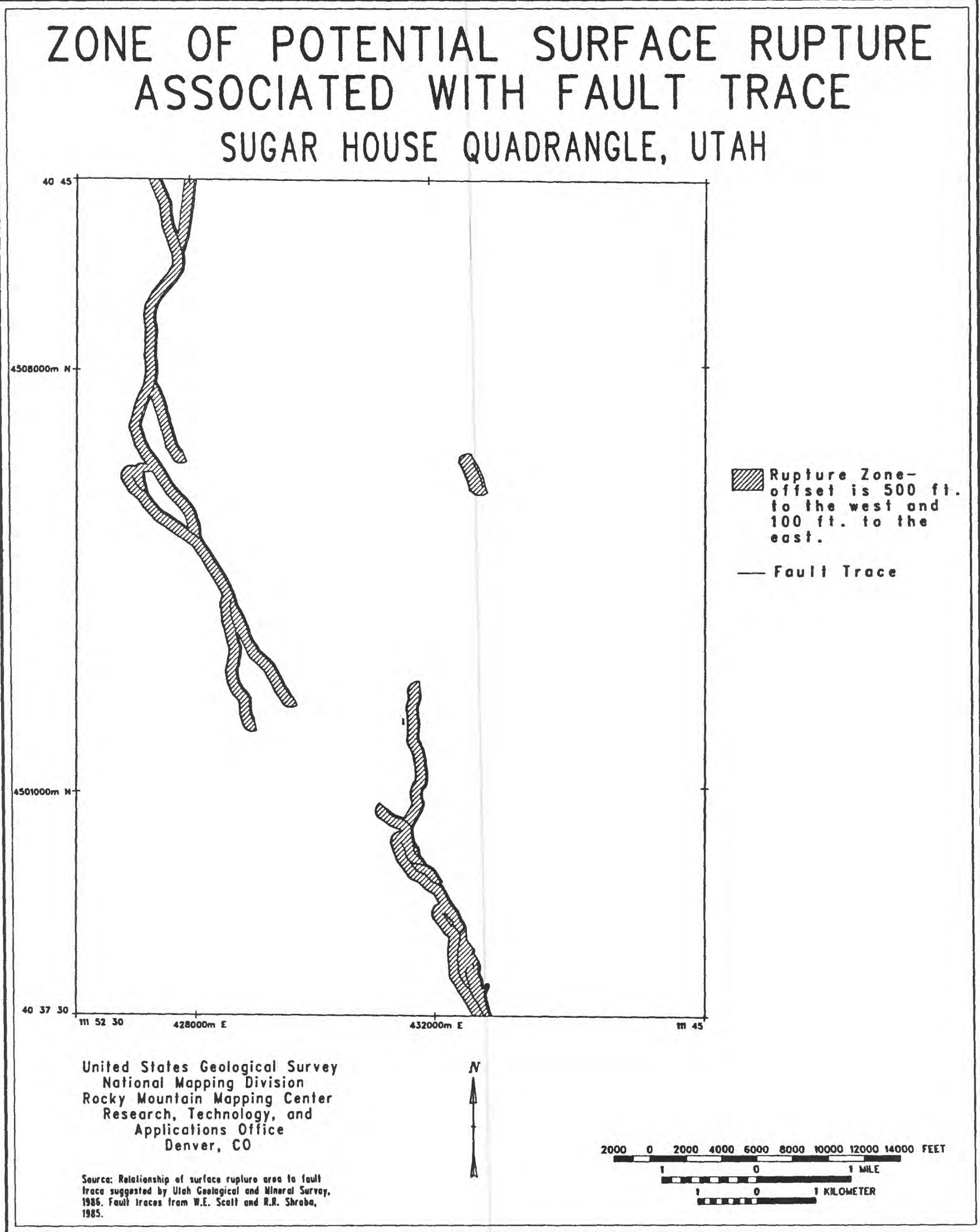




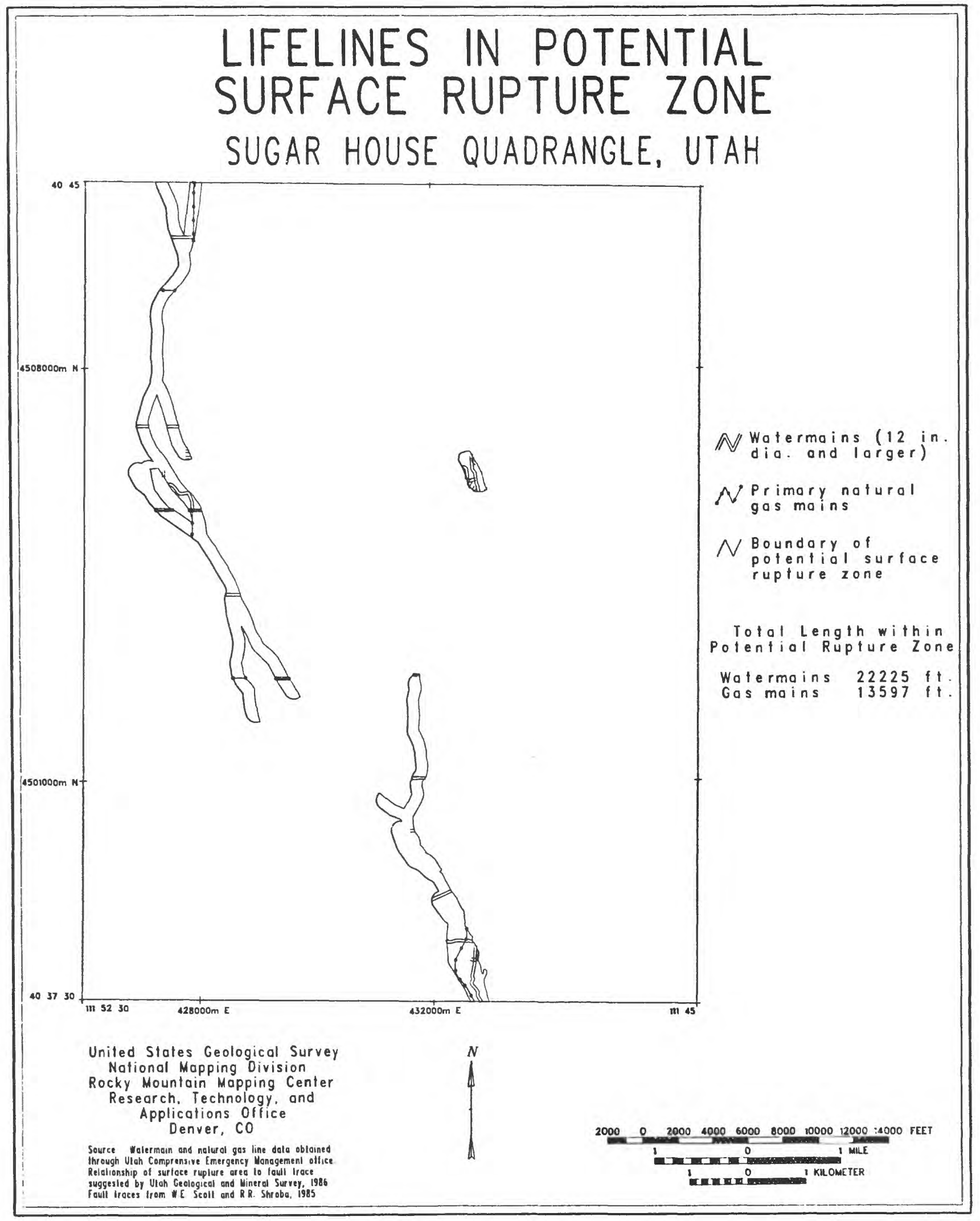




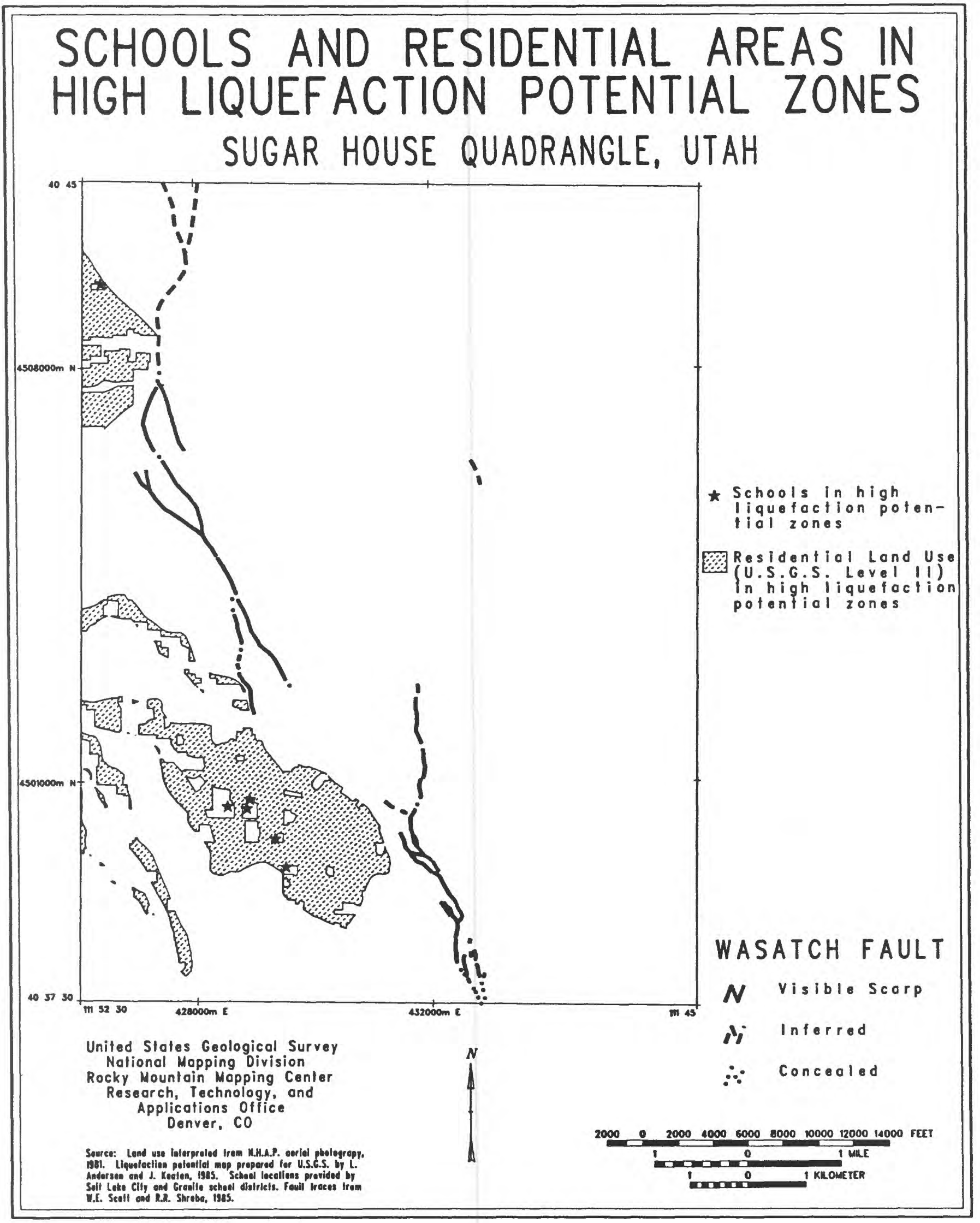




\section{SCHOOLS AND RESIDENTIAL AREAS ON LAND SURFACES WITH LOWEST STABILITY DURING EARTHQUAKES SUGAR HOUSE QUADRANGLE, UTAH}

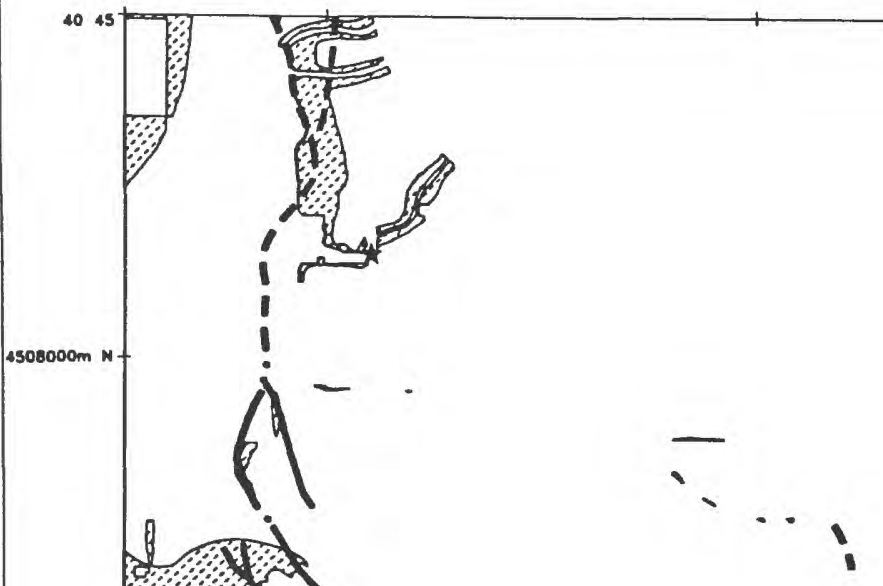

Schools on land surtaces with lowest stobility during orthquakes

Fesidentiol Land Use (U.S.G.S. Level II) on land surfaces with lowest stability during eorthquakes

WASATCH FAULT N Visible scorp

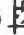

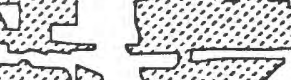
403730

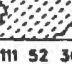

$$
428000 \mathrm{~m} \text { E }
$$

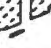

United States Geological Survey Notional Mopping Division

Rocky Mountain Mapping Center Research. Technology, and Applications Office Denver, Co

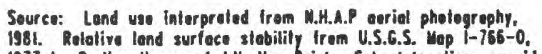

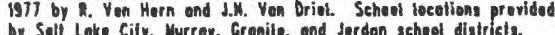
by Solt Lake Cify, Murrey. Gronite, end Jordon sehool districis.

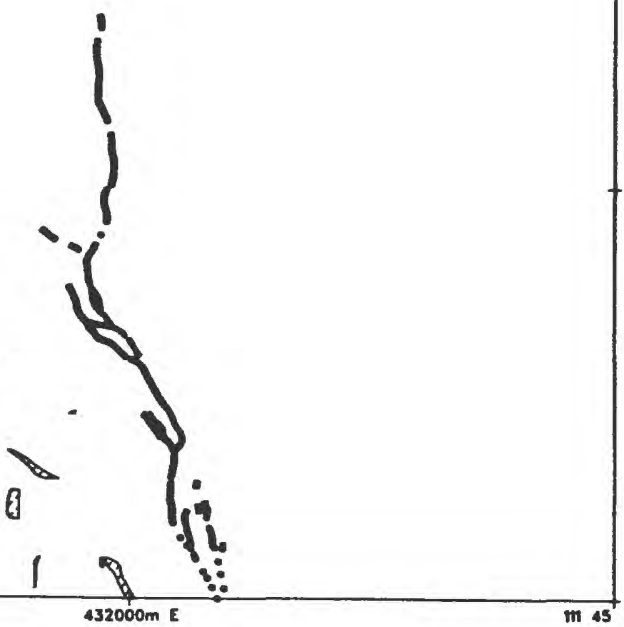

if Inferred

$\therefore$ Concealed foult ireces from W.E. Seett and R.R. Shrobe, 1985. 


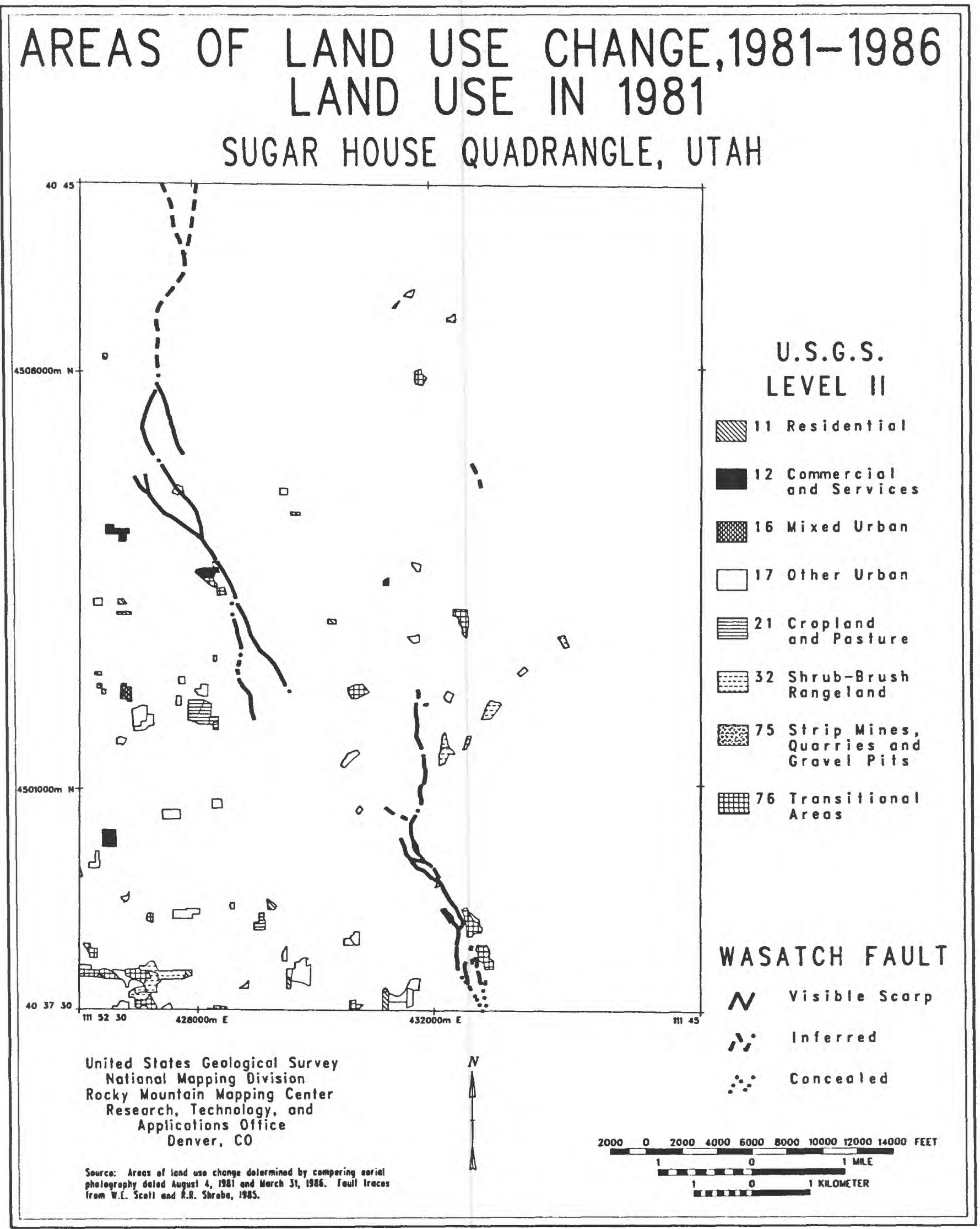




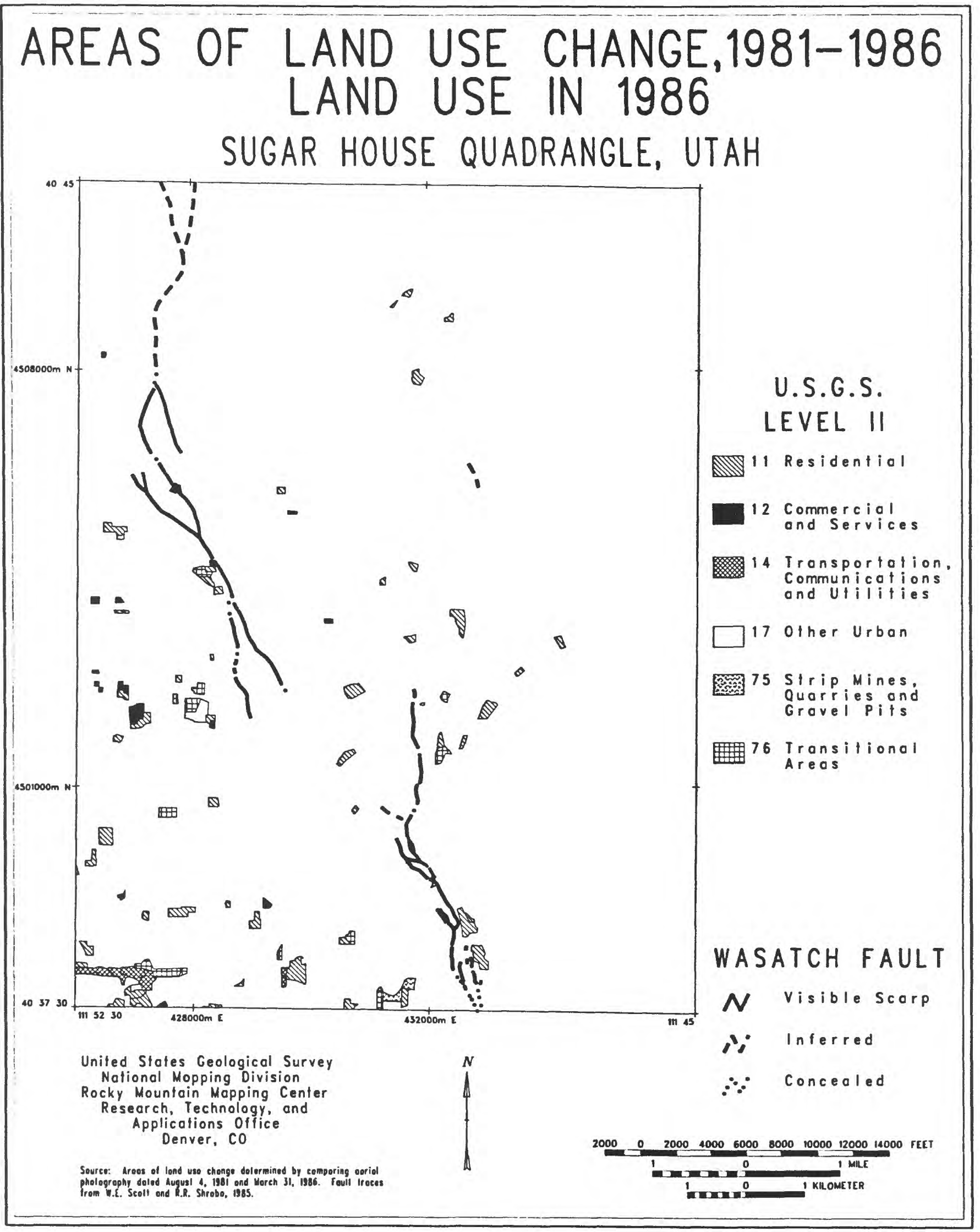




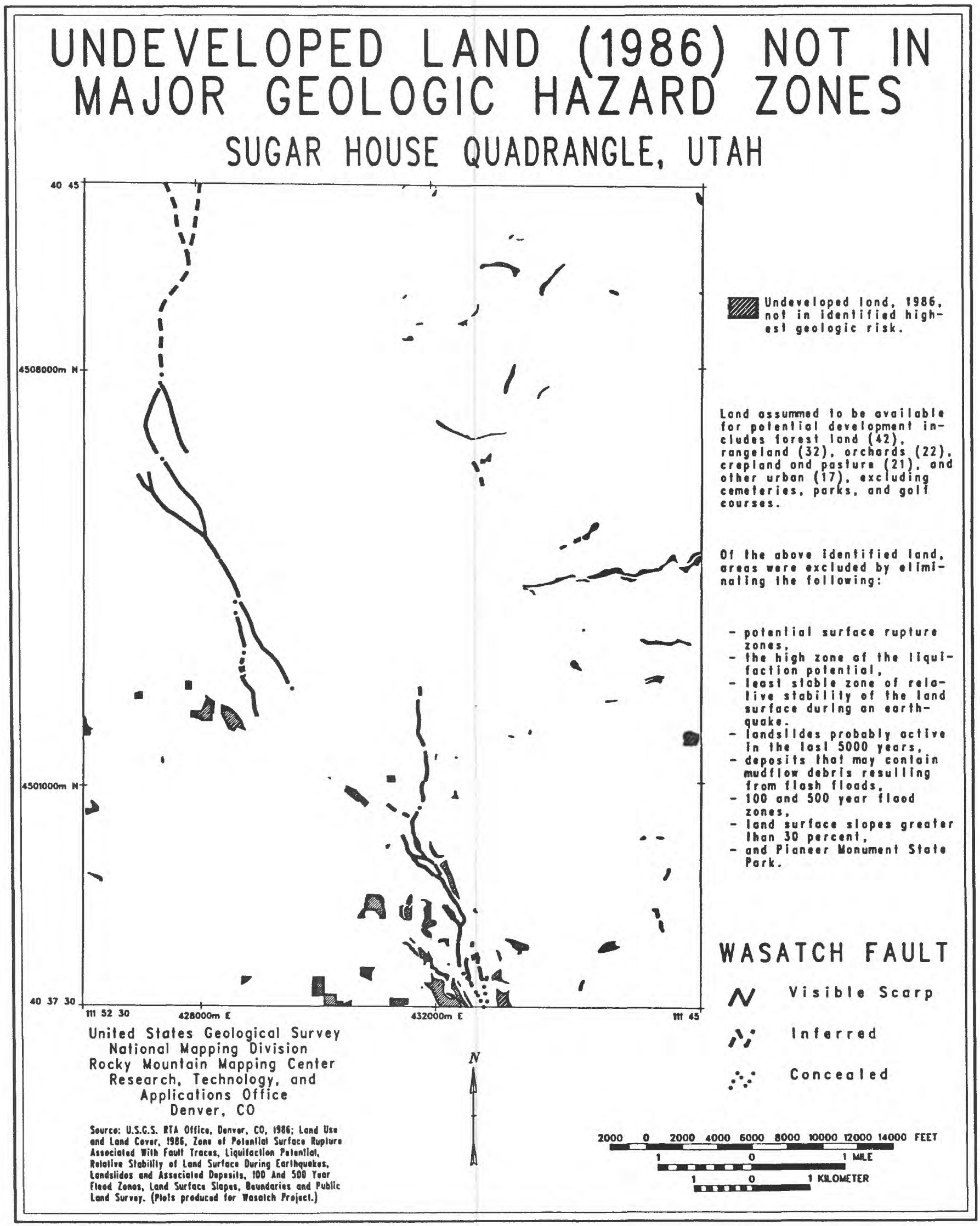




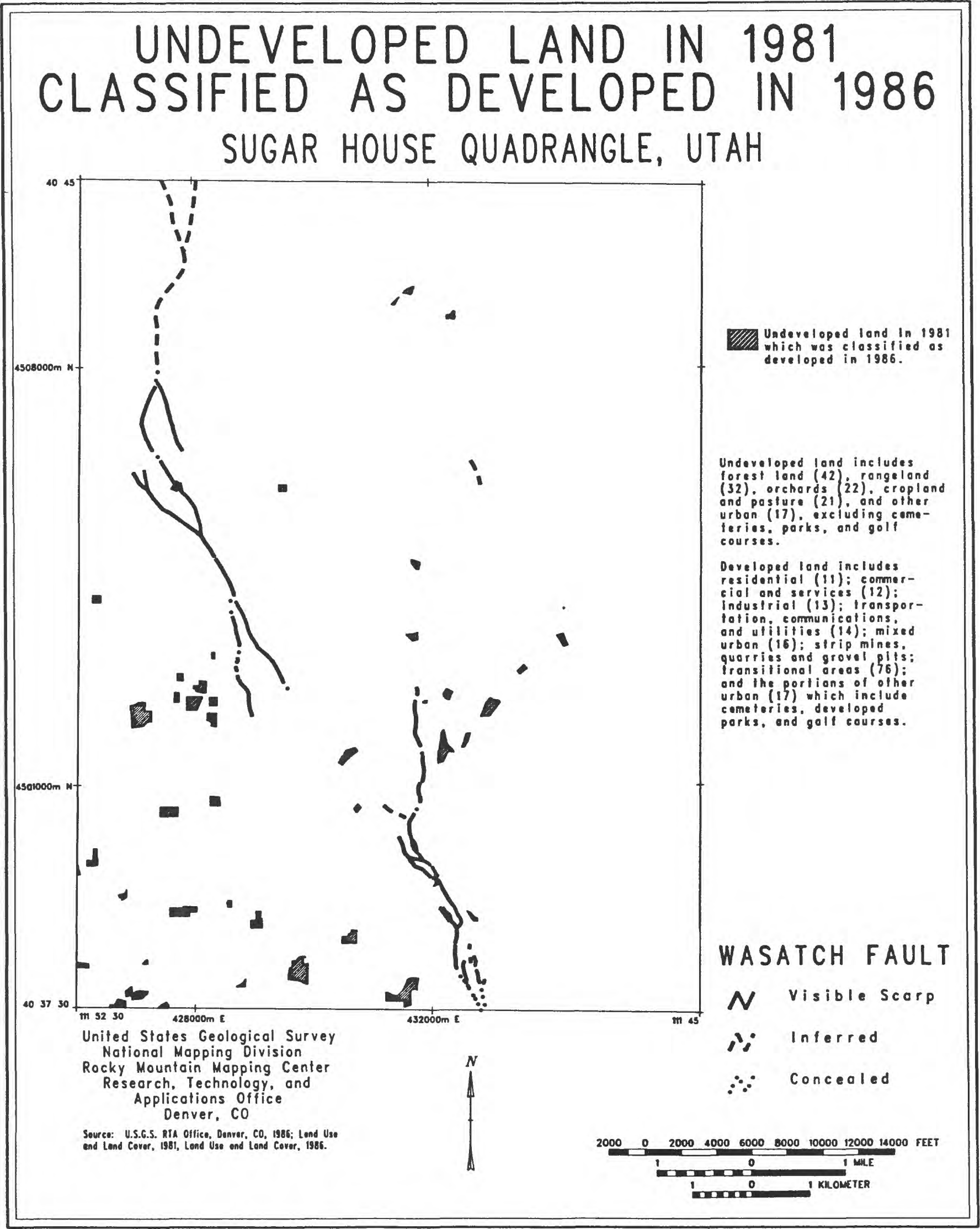




\section{URBAN GROWTH, 1890-1986 SUGAR HOUSE QUADRANGLE, UTAH}

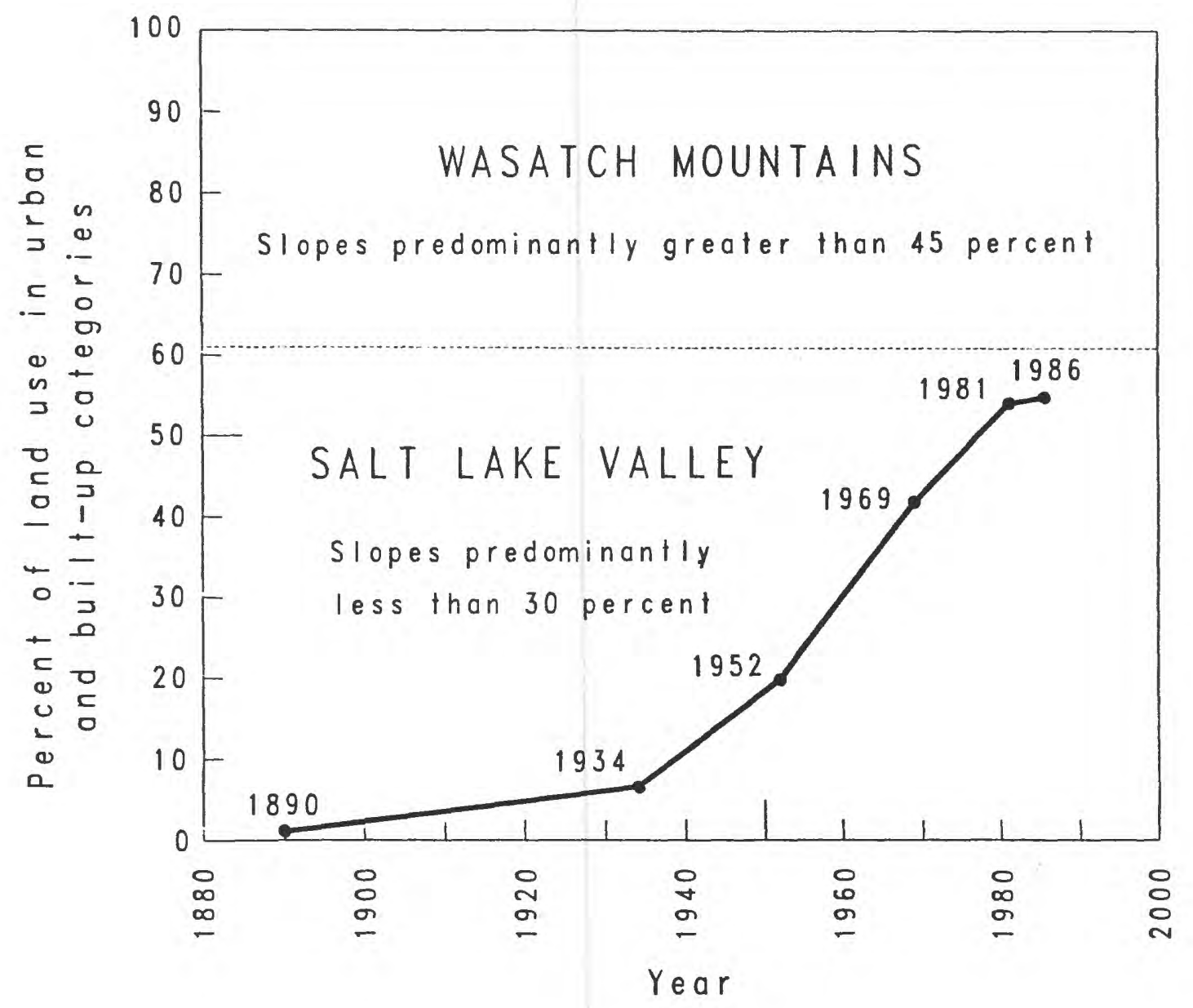

United States Geologicol Survey Notional Mopping Division

Rocky Mountoin Mopping Center

Reseorch. Technology, and

Applications office

Denver. $\mathrm{CO}$
Source. 45.65 . Yep 1-766-6. 1973 by Q Van Hore

Dete for 1981 end 1986 Irom U.S.G.S. RTA Ollice. Denver, 60 


\section{GROWTH OF BUILT-UP LAND, 1890-1986 INCREMENTAL \\ SUGAR HOUSE QUADRANGLE, UTAH}

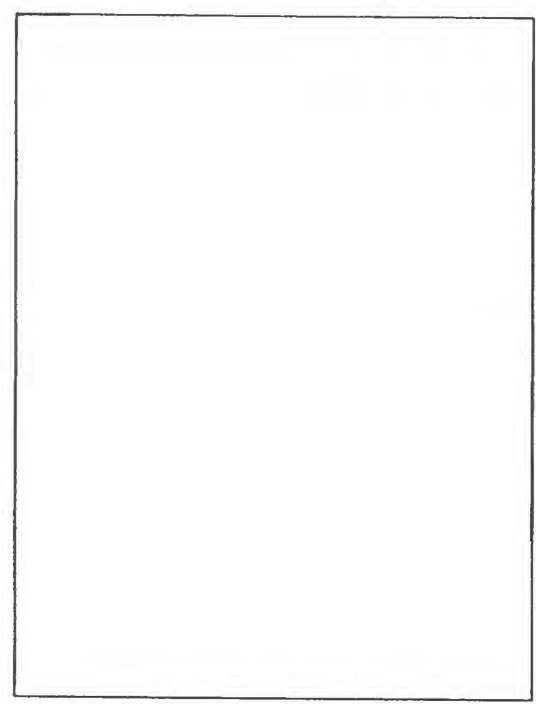

BUILT-UP AS OF 1890

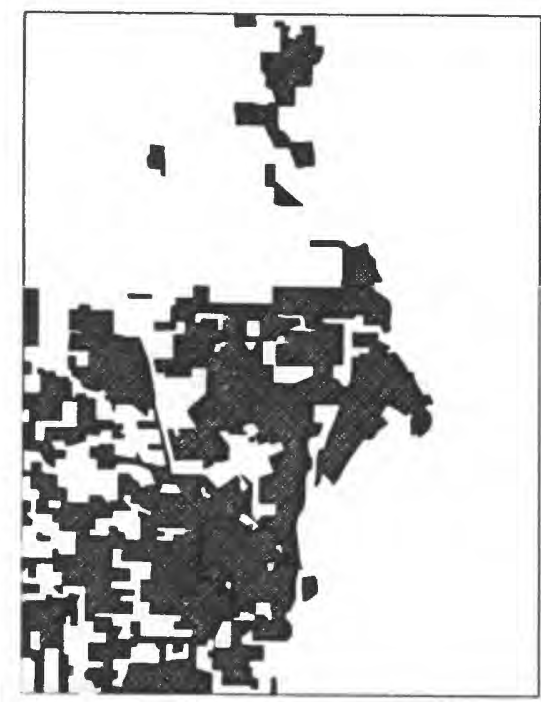

GROWTH BETWEEN 1952 AND 1969

United Slates Geological Survey National Mapping Division

Rocky Mountain Mopping Center Research, Technology, and Applications Office

$$
\text { Denver, CO }
$$

Source: U.S.C.S. Map 1-766-C. 197s by R. Yon Hor Dolo for 1981 and ises from U.S.G.S. RIA Ollieo. Denvor, CO.

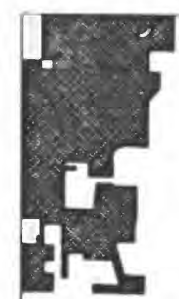

GROWTH BETWEEN 1890 AND 1934

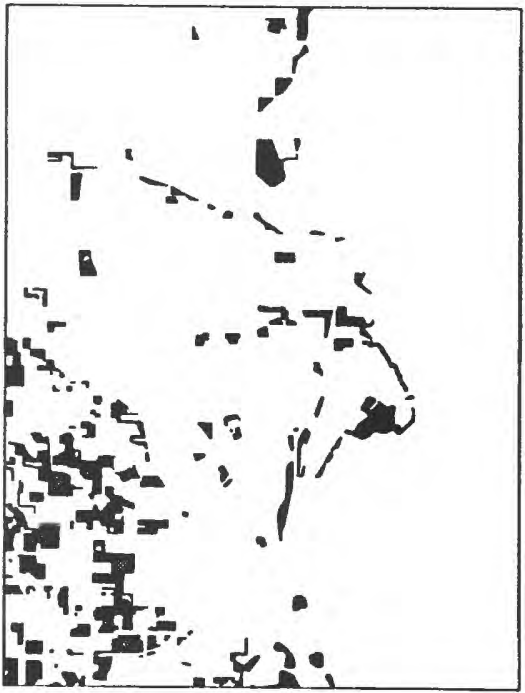

GROWTH BETWEEN 1969 AND 1981

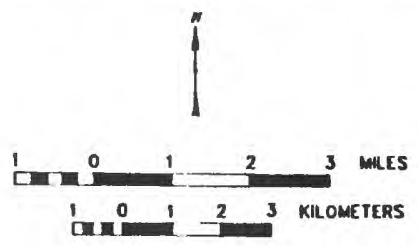

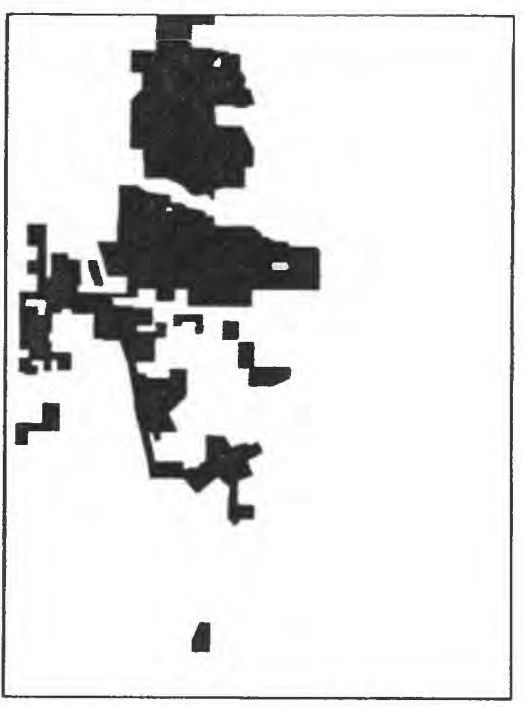

GROWTH BETWEEN 1934 AND 1952

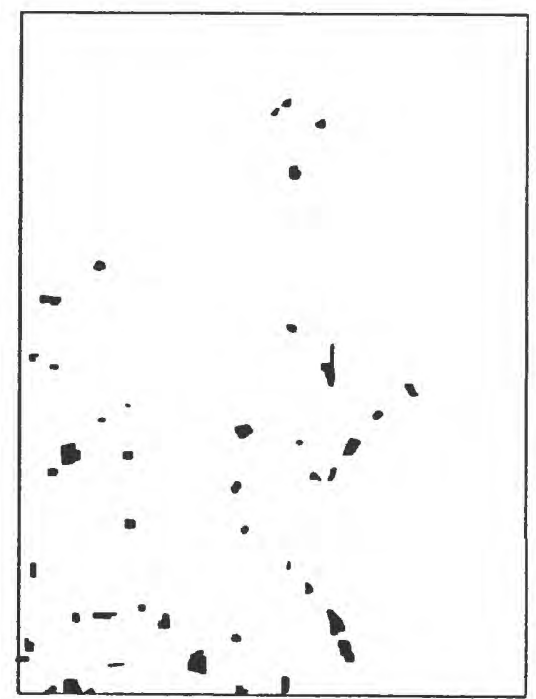

GROWIH BETWEEN 1981 AND 1986

Van Horn defined buill-up land os hoving of leost o 5 percent cover of structures. The U.S.G.S. land Use and Land Cover mapping specificafions require a density of of

least four houses per ten ocres lar residential land to be classified os urbon. 


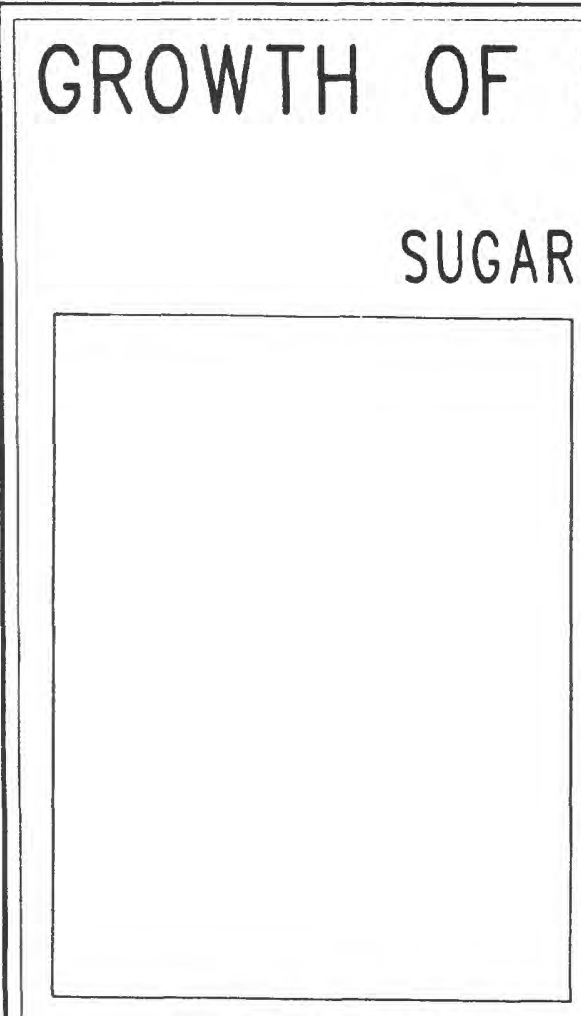

BUILT-UP AS OF 1890

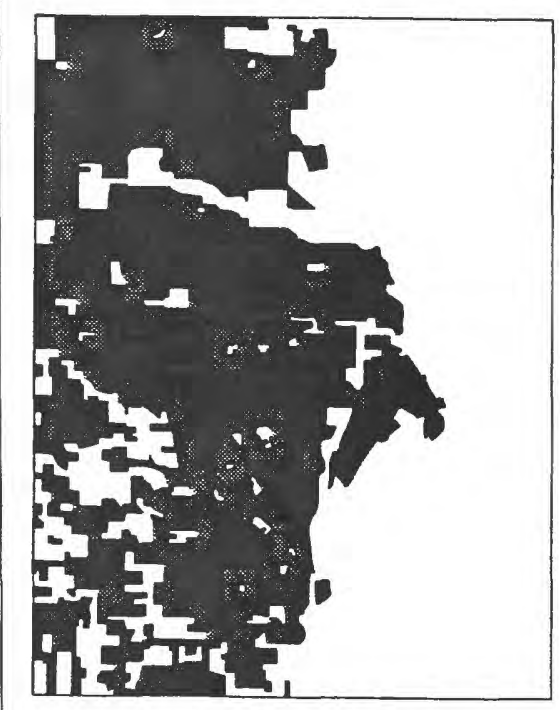

BUILT-UP AS OF 1969

United States Geological Survey National Mapping Division

Rocky Mountain Mapping Center Research. Technology, and Applications office Denver, CO

Source: U.S.C.S. Map 1-766-G, 1973 by R. Von Hern. Dale for 1989 ond 1986 from U.S.C.S. RTA Office. Danver, co.

BUILT-UP LAND, 1890-1986 CUMULATIVE

\section{HOUSE QUADRANGLE, UTAH}

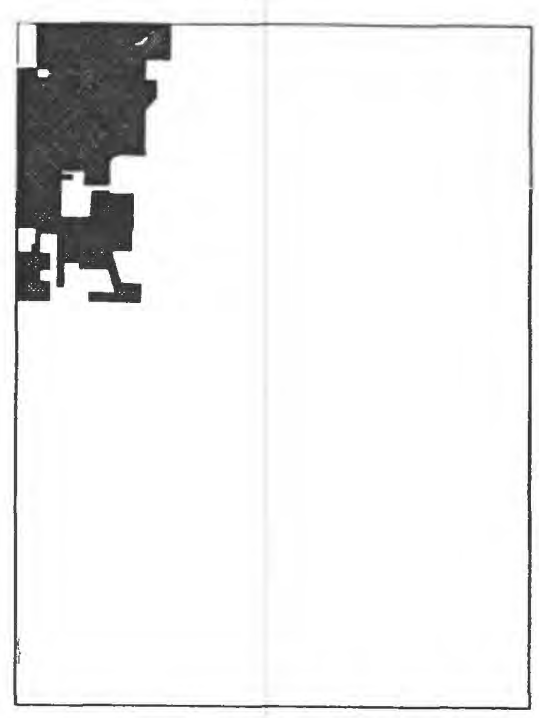

BUILT-UP AS OF 1934

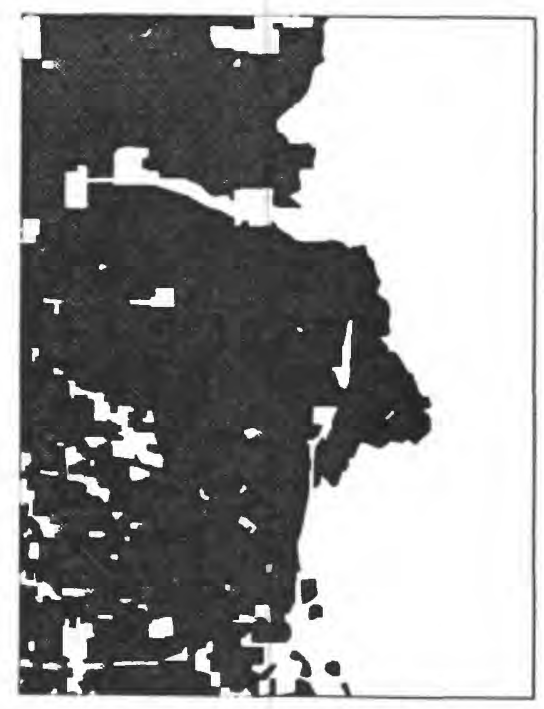

BUILT-UP AS OF 1981

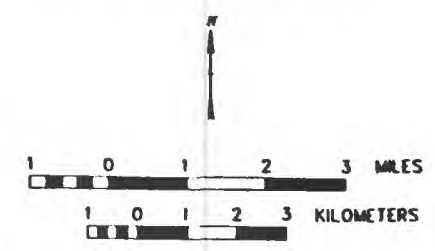

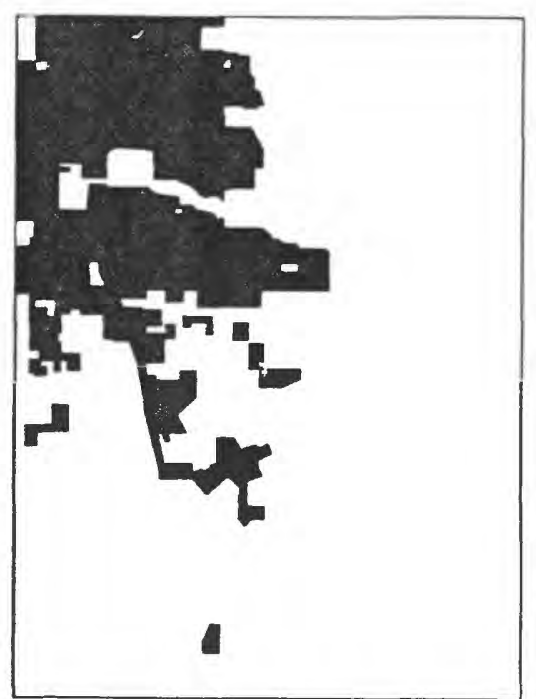

BUILT-UP AS OF 1952

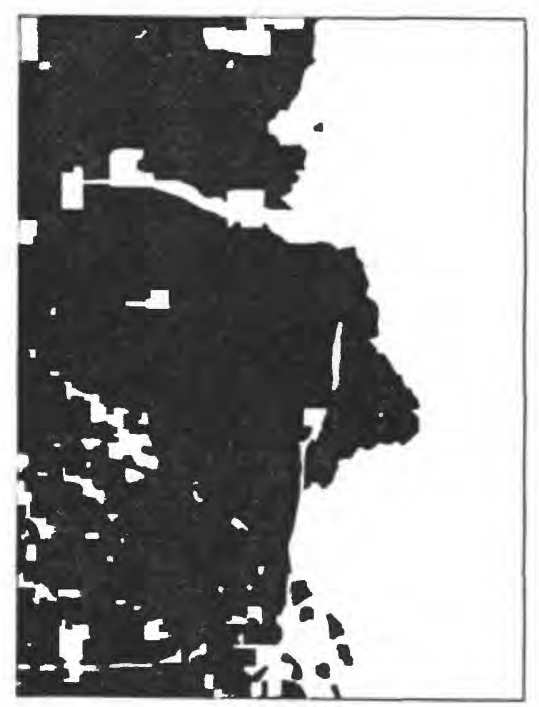

BUILT-UP AS OF 1986

Van Horn defined built-up land as hoving of least o 5 percent cover of structures. The U.S.G.S. Land Use and land Cover mopping specifications require a density of of cations require a density of of residential land to be clossified os urban. 
IMPLEMENTATION 


\title{
SUMMARY: EARTHQUAKE APPLICATIONS EXAMPLES
}

\author{
EARTH SCIENCE RESEARCH \\ LOSS ESTIMATION \\ LAND USE PLANNING \\ DISASTER RESPONSE AND RECOVERY \\ MONITORING CHANGE
}

This research/demonstration project identified potential applications of digital map data bases and geographic information systems to several aspects of the interdisciplinary field of earthquake hazard assessment and reduction.

Earth science research. Having geological and geophysical data (2 or 3 dimensional) in digital format may assist in the earth science research components of the Earthquake Hazard Reduction Program (e.g., analyzing seismic data; synthesizing geological and geophysical data for evaluation of earthquake hazards; ground motion modeling; and obtaining digital color maps prior to publication, to aid in the interpretation process.

Loss estimation. Estimating expected losses from future earthquakes is an important part of planning to enable communities to anticipate and prepare for an orderly recovery.

Land use planning. Maps of the expected zones of severe earthquake hazard can be used by local governments and others to guide future development away from such zones, or to enable developers to incorporate earthquakeresistant design in new structures planned within hazard zones.

Disaster response and recovery. Quick access to data on locations and characteristics of lifelines and other critical facilities can assist emergency management officials in planning for response and recovery from future disasters.

Monitoring change. Computerized map data bases can help local and state government agencies monitor growth and other changes that can affect the ability to deliver emergency response services in time of disaster. Also, changes in the introduction of building codes and other hazard mitigation measures in earthquake hazard zones can be monitored with the aid of such data bases. 


\title{
DEVELOPING INFORMATION BASE FOR IMPACTED REGION
}

\author{
DEVISE IMPLEMENTATION STRATEGY \\ DETERMINE USERS' NEEDS AND CAPABILITIES \\ ENCOURAGE COOPERATION AND DATA SHARING \\ WORK TOWARD CONSENSUS ON DATA STANDARDS \\ BUILD REGIONAL INFORMATION MANAGEMENT SYSTEM
}

Applying the results of this research project to implementation of earthquake hazard reduction in Utah would involve a long-term cooperative program based on a continuing phase of research and development. However, steps could be taken now to begin the process of building the information base on which implementation would depend.

An early strategic planning effort is recommended to devise an implementation strategy, which would take into account immediate and longrange information needs and availability, assuming that damaging earthquakes could occur at any time from the present day forward.

A detailed survey and technical description of users' needs and capabilities will be required as input for the design of a cooperative information system to serve those needs. A basis on which to build was provided by participants in the Project Workshop, September 10, 1986.

Specific efforts from those in leadership positions should be directed toward encouraging cooperation and data sharing, which will be necessary to assure that data produced in one agency will be usable in another, and to minimize costly duplication.

A necessary step to a data sharing capability is to work toward a consensus on data standards, taking into account the various hardware and software systems which will be used to handle the data.

A regional information management system, with leadership assigned at state government level, is recommended in the operational phases of the maintenance of earthquake hazard information readiness. 
PLATE 29

\section{MULTI-SCALE MAP LINKAGES}

$\begin{array}{ll}1: 100,000-1,500: 000 & \text { REGIONAL } \\ 1: 24,0000 & \text { QUADRANGLE } \\ 1: 4,800-1: 1,200 & \text { LOCAL }\end{array}$

To provide the information services identified by Project Workshop participants, computer-to-computer linkages among data bases derived from maps at several input scales will be required. The topographic quadrangle scale of 1:24,000 used in the project demonstrations is useful for assembling geologic, hydrologic, land use, lifeline, and response facilities for planning purposes. Scales of 1:4,800 and larger are needed to accommodate data on building characteristics and other data that are typically keyed to local government land parcel files, and to utility companies' distribution facilities records. An example of linkages to large-scale maps and local government land parcel files is illustrated in P1ate 30. Scales of 1:100,000 and smaller are needed to portray the geographic scope of earthquake hazards and their consequences to officials in the entire impacted area; smaller-scale displays will also be useful as indexes to areal coverages being compiled at more-detailed levels (e.g., P1ate 1). 


\title{
DATA BASES FOR LOSS ESTIMATION
}

\author{
EARTHQUAKE SCENARIOS \\ HAZARD ZONES \\ INTENSITY/DAMAGE RANGES \\ VULNERABLE POPULATIONS \\ VULNERABLE STRUCTURES
}

State government officials at the Project Workshop September 10, 1986, declared that the preparation at state level of data bases for earthquake loss estimation would be both useful and technically achievable as a component of implementation of earthquake hazard reduction in Utah. Further proof-of-concept research is recommended to determine the feasibility of implementing a loss estimation capability.

Loss estimation data bases and analysis capability would include: modeling various earthquake scenarios in computer systems compatible with the formats of the required data bases; map data delineating several earthquake hazard zones, such as liquefaction, fault rupture, and ground motion due to shaking; expected or predicted acceleration, intensity, and damage ranges for characteristics earthquakes; and data bases on vulnerable populations, vulnerable structures, and other physical and socio-economic phenomena as needed. 


\section{DIAGRAMMATIC RELATIONSHIP OF LAND OWNERSHIP PARCELS AND OTHER DATA BASES SUGAR HOUSE QUADRANGLE, UTAH}

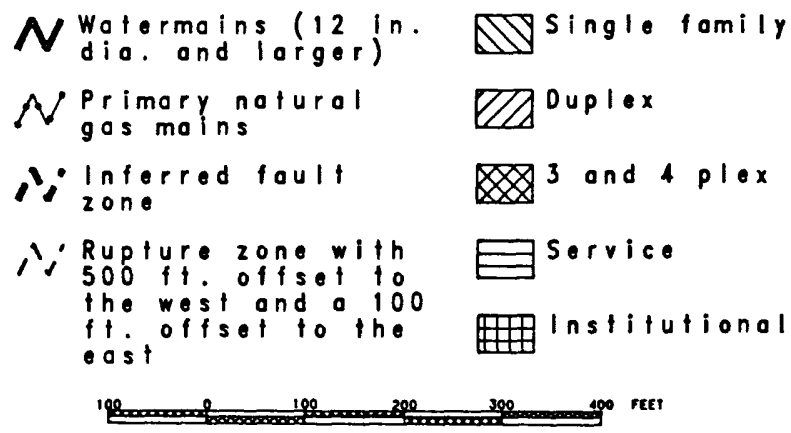

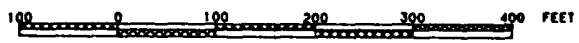

DATA BASE FOR LAND OWNERSHIP IN CENSUS BLOCK 208 IN RELATION TO CRITICAL LIFELINES AND FAULT

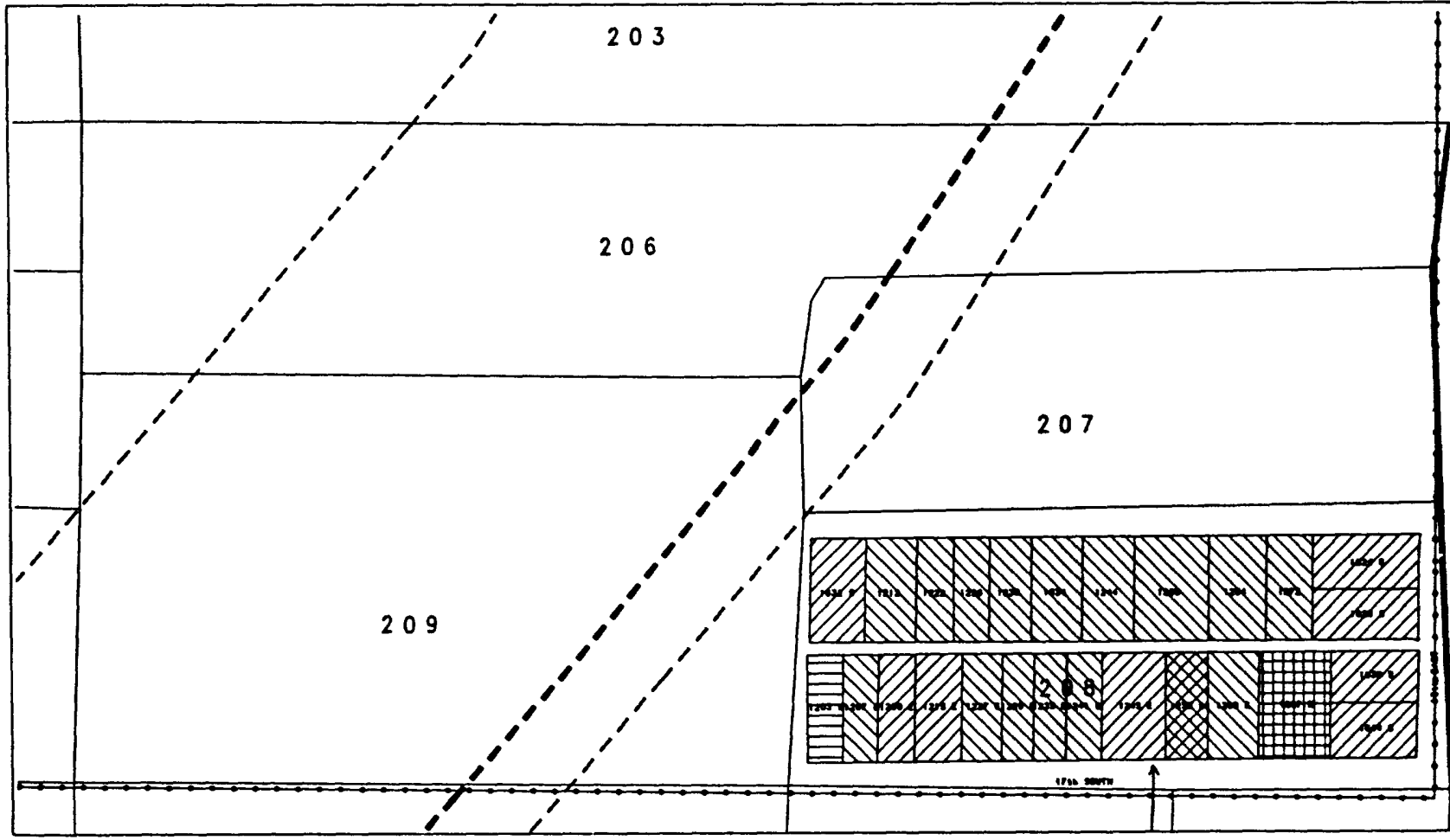

United States Geological Survey Notional Mopping Division

Rocky Mountain Mapping Center Reseorch, Technology, and Applications Office Denver, CO

Soures: U.S. Iuroeu of the Congus 13 so consus Iroct dole. 1502. Foult trees tram X.E. Sestl oad k. Strobe, 1985. Rolelionahip of aurfece ores to toulf

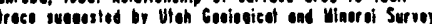

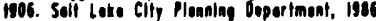
volermoin and motur ol gas moin doth abieinod threugh

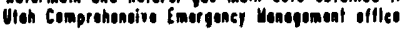

TYPICAL LAND PARCEL DATA

AREATETER : : $\quad 886.801$

PRR P

ASORESS : 124505

GL REAGE

OES OR T P

OFLOORS

A Y A L U E
$22 \%$

$\quad 260.000 .00$ 


\section{GLOSSARY OF TERMS USED IN EARTHQUAKE HAZARDS ASSESSMENTS}

Accelerogram. The record from an accelerometer showing acceleration as a function of time. The peak acceleration is the largest value of acceleration on the accelerogram.

Acceptable Risk. A probability of occurrences of social or economic consequences due to earthquakes that is sufficiently low (for example in comparison to other natural or manmade risks) as to be judged by appropriate authorities to represent a realistic basis for determining design requirements for engineered structures, or for taking certain social or economic actions.

Active fault. A fault is active if, because of its present tectonic setting, it can undergo movement from time to time in the immediate geologic future. This active state exists independently of the geologists' ability to recognize it. Geologists have used a number of characteristics to identify active faults, such as historic seismicity or surface faulting, geologically recent displacement inferred from topography or stratigraphy, or physical connection with an active fault. However, not enough is known of the behavior of faults to assure identification of all active faults by such characteristics. Selection of the criteria used to identify active faults for a particular purpose must be influenced by the consequences of fault movement on the engineering structures involved.

Asthenosphere. The worldwide layer below the lithosphere which is marked by low seismic wave velocities. It is a soft layer, probably partially molten.

Attenuation law. A description of the average behavior of one or more characteristics of earthquake ground motion as a function of distance from the source of energy.

Attenuation. A decrease in seismic signal strength with distance which depends not only on geometrical spreading, but also may be related to the physical characteristics of the transmitting medium that cause absorption and scattering.

b-value. A parameter indicating the relative frequency of earthquakes of different sizes derived from historical seismicity data.

Capable fault. A fault along which future surface displacement is possible, especially during the lifetime of the engineering project under consideration.

Convection. A mechanism of heat transfer through a liquid in which hot material from the bottom rises because of its lesser density, while cool surface materials sinks.

Convergence Zone. A band along which moving plates collide and area is lost either by shortening and crustal thickening or subduction and destruction of crust. The site of volcanism, earthquakes, trenches, and mountain building. 
Design earthquake. A specification of the ground motion at a site based on integrated studies of historic seismicity and structural geology used for the earthquake-resistant design of a structure.

Design spectra. Spectra used in earthquake-resistant design which correlate with design earthquake ground motion values. Design spectra typically are smooth curves that take into account features peculiar to a geographic region and a particular site.

Design time history. One of a family of time histories used in earthquakeresistant design which produces a response spectrum enveloping the smooth design spectrum, for a selected value of damping.

Duration. A qualitative or quantitative description of the length of time during which ground motion at a site exhibits certain characteristics such as being equal to or exceeding a specified level of acceleration such as $0.05 \mathrm{~g}$.

Earthquake hazards. The probability that natural events accompanying an earthquake such as ground shaking, ground failure, surface faulting, tectonic deformation, and inundation, which may cause damage and loss of life, will occur at a site during a specified exposure time. See earthquake risk.

Earthquake risk. The probability that social or economic consequences of earthquakes, expressed in dollars or casualties, will equal or exceed specified values at a site during a specified exposure time.

Earthquake waves. Elastic waves (, , S, Love, Rayleigh) propagating in the Earth, set in motion by faulting of a portion of the Earth.

Effective peak acceleration. The peak ground acceleration after the groundmotion record has been filtered to remove the very high frequencies that have little or no influence upon structural response.

Elastic rebound theory. A theory of fault movement and earthquake generation that holds that faults remain lock while strain energy accumulates in the rock, and then suddenly slip and release this energy.

Epicenter. The point on the Earth's surface vertically above the point where the first fault rupture and the first earthquake motion occur.

Exceedance probability. The probability (for example, 10 percent) over some period of time that an event will generate a level of ground shaking greater than some specified level.

Exposure time. The period of time (for example, 50 years) that a structure is exposed to the earthquake threat. The exposure time is sometimes related to the design lifetime of the structure and is used in seismic risk calculations.

Fault. A fracture or fracture zone in the Earth along which displacement of the two sides relative to one another has occurred parallel to the fracture. See Active and Capable faults. 
Focal depth. The vertical distance between the hypocenter and the Earth's surface in an earthquake.

Ground motion. A general term including all aspects of motion; for example, particle acceleration, velocity, or displacement; stress and strain; duration; and spectral content generated by a nuclear explosion, an earthquake, or another energy source.

Intensity. A numerical index describing the effects of an earthquake on the Earth's surface, on man, and on structures built by him. The scale in common use in the United States today is the Modified Mercalli scale of 1931 with intensity values indicated by Roman numerals from I to XII. The narrative descriptions of each intensity value are summarized below.

I. Not felt--or, except rarely under especially favorable circumstances. Under certain conditions, at and outside the boundary of the area in which a great shock is felt: sometimes birds and animals reported uneasy or disturbed; sometimes dizziness or nausea experienced; sometimes trees, structures, liquids, bodies of water, may sway--doors may swing, very slowly.

II. Felt indoors by few, especially on upper floors, or by sensitive, or nervous persons. Also, as in grade $I$, but of ten more noticeably: sometimes hanging objects may swing, especially when delicately suspended; sometimes trees, structures, liquids, bodies of water, may sway, doors may swing, very slowly; sometimes birds and animals reported uneasy or disturbed; sometimes dizziness or nausea experienced.

III. Felt indoors by several, motion usually rapid vibration. Sometimes not recognized to be an earthquake at first. Duration estimated in some cases. Vibration like that due to passing of light, or lightly loaded trucks, or heavy trucks some distance away. Hanging objects may swing slightly. Movements may be appreciable on upper levels of tall structures. Rocked standing motor cars slightly.

IV. Felt indoors by many, outdoors by few. Awakened few, especially light sleepers. Frightened no one, unless apprehensive from previous experience. Vibration like that due to passing of heavy or heavily loaded trucks. Sensation like heavy body of striking building or falling of heavy objects inside. Rattling of dishes, windows, doors; glassware and crockery clink or clash. Creaking of walls, frame, especially in the upper range of this grade. Hanging objects swung, in numerous instances. Disturbed liquids in open vessels slightly. Rocked standing motor cars noticeably.

V. Felt indoors by practially all, outdoors by many or most; outdoors direction estimated. Awakened many or most. Frightened few--slight excitement, a few ran outdoors. Buildings trembled throughout. Broke dishes and glassware to some extent. Cracked windows--in some cases, but not generally. Overturned vases, small or unstable objects, in many instances, with occasional fall. Hanging objects, doors, swing generally or considerably. Knocked pictures against walls, or swung them out of place. Opened, or closed, doors and shutters abruptly. Pendulum clocks stopped, started or ran fast, or slow. Move sma11 
objects, furnishings, the latter to slight extent. Spilled liquids in small amounts from well-filled open containers. Trees and bushes shaken slightly.

VI. Felt by all, indoors and outdoors. Frightened many, excitement general, some alarm, many ran outdoors. Awakened all. Persons made to move unsteadily. Trees and bushes shaken slightly to moderately. Liquid set in strong motion. Small bells rang--church, chapel, school, etc. Damage slight in poorly built buildings. Fall of plaster in small amount. Cracked plaster somewhat, es pecially fine cracks chimneys in some instances. Broke dishes, glassware, in considerable quantity, also some windows. Fall of knickknacks, books, pictures. Overturned furniture in many instances. Move furnishings of moderately heavy kind.

VII. Frightened all--general alarm, all ran outdoors. Some, or many, found it difficult to stand. Noticed by persons driving motor cars. Trees and bushes shaken moderately to strongly. Waves on ponds, lakes, and running water. Water turbid from mud stirred up. Incaving to some extent of sand or gravel stream banks. Rang large church bells, etc. Suspended objects made to quiver. Damage negligible in buildings of good design and construction, slight to moderate in well-built ordinary buildings, considerable in poorly built or badly designed buildings, adobe houses, old walls (especially where laid up without mortar), spires, etc. Cracked chimneys to considerable extent, walls to some extent. Fall of plaster in considerable to large amount, also some stucco. Broke numerous windows and furniture to some extent. Shook down loosened brickwork and tiles. Broke weak chimneys at the roof-line (sometimes damaging roofs). Fall of cornices from towers and high buildings. Dislodged bricks and stones. Overturned he avy furniture, with damage from breaking. Damage considerable to concrete irrigation ditches.

VIII.Fright general--alarm approaches panic. Disturbed persons driving motor cars. Trees shaken strongly--branches and trunks broken of $f$, especially palm trees. Ejected sand and mud in small amounts.

Changes: temporary, pe rmanent; in flow of springs and wells; dry wells renewed flow; in temperature of spring and well waters. Damage slight in structures (brick) built es pecially to withstand earthquakes. Considerable in ordinary substantial buildings, partial collapse, racked, tumbled down, wooden houses in some cases; threw out panel walls in frame structures, broke of $\mathrm{f}$ decayed piling. Fall of walls, cracked, broke, solid stone walls seriously. Wet ground to some extent, also ground on steep slopes. Twisting, fall, of chimneys, columns, monuments, also factory stacks, towers. Moved conspicuously, overturned, very heavy furniture.

IX. Panic general. Cracked ground conspicuously. Damage considerable in (masonry) buildings, some collapse in large part; or wholly shifted frame buildings of foundations, racked frames; serious to reservoirs; underground pipes sometimes broken.

X. Cracked ground, especially when loose and wet, up to widths of several inches; fissures up to a yard in width ran parallel to canal and stream banks. Landslides considerable from river banks and steep coasts. 
Shifted sand and mud horizontally on beaches and flat land. Changes level of water in wells. Threw water on banks of canals, lakes, rivers, etc. Damage serious to dams, dikes, embankments. Severe to we11-built wooden structures and bridges, some destroyed. Developed dangerous cracks in excellent brick walls. Destroyed most masonry and frame structures, also their foundations. Bent railroad rails slightly. Tore apart, or crushed endwise, pipelines buried in earth. Open cracks and broad wavy folds in cement pavements and asphalt road surfaces.

XI. Disturbances in ground many and widespread, varying with ground material. Broad fissures, earth slumps, and land slips in soft, wet ground. Ejected water in large amounts charged with sand and mud. Caused sea-waves ("tidal" waves) of significant magnitude. Damage severe to wood-frame structures, especially near shock centers. Great to dams, dikes, embankments of ten for long distances. Few, if any (masonry) structures, remained standing. Destroyed large wel1-built bridges by the wrecking of supporting piers or pillars. Affected yielding wooden bridges less. Bent railroad rails greatly, and thrust them endwise. Put pipelines buried in each completely out of service.

XII. Damage total--practically all works of construction damaged greatly or destroyed. Disturbances in ground great and varied, numerous shearing cracks. Landslides, falls of rock of significant character, slumping of river banks, etc., numerous and extensive. Wrenched loose, tore of $f$, large rock masses. Fault slips in firm rock, with notable horizontal and vertical offset displacements. Water channels, surface and underground, disturbed and modified greatly. Dammed lakes, produced waterfalls, deflected rivers, etc. Waves seen on ground surfaces (actually seen, probably, in some cases). Distorted lines of sight and leve1. Threw objects upward into the air.

Liquefaction. Temporary transformation of unconsolidated materials into a fluid mass.

Lithosophere. The outer, rigid shell of the earth, situated above the asthenosphere containing the crust, continents, and plates.

Magnitude. A quantity characteristic of the total energy released by an earthquake, as contrasted to intensity that describes its effects at a particular place. Professor C. F. Richter devised the logarithmic scale for local magnitude $\left(M_{L}\right)$ in 1935. Magnitude is expressed in terms of the motion that would be measured by a standard type of selsmograph located $100 \mathrm{~km}$ from the epicenter of an earthquake. Several other magnitude scales in addition to $\mathrm{M}_{\mathrm{L}}$ are in use; for example, body-wave magnitude $\left(\mathrm{m}_{\mathrm{b}}\right)$ and surface-wave magnitude $\left(M_{S}\right)$, which utilize body waves and surface waves, and local magnitude $\left(M_{L}\right)$. The scale is open ended, but the largest known earthquake have had $M_{S}$ magnitudes near 8.9 .

Mantle. The main bulk of earth between the crust and core, ranging from depths of about 40 to 2900 kilometers.

Mid-oceanridge. Characteristic type of plate boundary occurring in a divergence zone, a site where two plates are being pulled apart and new oceanic lithosphere is being created. 
Plate tectonics. The theory and study of plate formation, movement, interaction, and destruction.

Plate. One of the dozen or more segments of the lithosphere that are internally rigid and move independently over the interior, meeting in convergence zones and separating in divergence zones.

Region. A geographical area, surrounding and including the construction site, which is sufficiently large to contain all the geologic features related to the evaluation of earthquake hazards at the site.

Response spectrum. The peak response of a series of simple harmonic oscillators having different natural periods when subjected mathematically to a

particular earthquake ground motion. The response spectrum may be plotted as a curve on tripartite logarithmic graph paper showing the variations of the peak spectral acceleration, displacement, and velocity of the oscillators as a function of vibration period and damping.

Return period. For ground shaking, return period denotes the average period of time or recurrence interval between events causing ground shaking that exceeds a particular level at a site; the reciprocal of annual probability of exceedance. A return period of 475 years means that, on the average, a particular level of ground motion will be exceeded once in $47 \overline{5 \text { years. }}$

Risk. See earthquake risk.

Rock. Any solid rock either at the surface or underlying soil having a shearwave velocity 2,500 $765 \mathrm{~m} / \mathrm{s})$ at $\mathrm{smal1}(0.0001$ percent $)$ strains.

Sea-floor spreading. The mechanism by which new sea floor crust is created at ridges in divergence zones and adjacent plates are moved apart to make room.

Seismic Microzoning. The division of a region into geographic areas having a similar relative response to a particular earthquake hazard (for example, ground shaking, surface fault rupture, etc.). Microzoning requires an integrated study of: 1) the frequency of earthquake occurrence in the region, 2) the source parameters and mechanics of faulting for historical and recent earthquakes affecting the region, 3) the filtering characteristics of the crust and mantle constituting the regional paths along which the seismic waves travel, and 4) the filtering characteristics of the near-surface column of rock and soil.

Seismic zone. A generally large area within which seismic design requirements for structures are uniform.

Seismotectonic province. A geographic area characterized by similarity of geological structure and earthquake characteristics. The tectonic processes causing earthquakes have been identified in a seismotectonic province.

Source. The source of energy release causing an earthquake. The source is characterized by one or more variables, for example, magnitude stress drop, seismic moment. Regions can be divided into areas having spatially homogeneous source characteristics. 
Strain. A quantity describing the exact deformation of each point in a body. Roughly the change in a dimension or volume divided by the original dimension or volume.

Stress. A quantity describing the forces acting on each part of a body in units of force per unit area.

Strong motion. Ground motion of sufficient amplitude to be of engineering interest in the evaluation of damage due to earthquakes or in earthquakeresistant design of structures.

Subduction zone. A dipping planar zone descending away from a trench and defined by high seismicity, interpreted as the shear zone between a sinking oceanic plate and an overriding plate.

Transform fault. A strike-slip fault connecting the ends of an of fset in a midocean ridge. Some pairs of plates slide past each other along transform faults.

Trench. A long and narrow deep trough in the sea floor; interpreted as marking the line along which a plate bends down into a subduction zone.

Triple junction. A point that is common to three plates and which must be the meeting place of three boundary features, such as convergence zones, divergence zones, or transform faults. 
LOCATION OF STRONG MOTION INSTRUMENTS IN UTAH

\author{
By \\ Richard Maley \\ U.S. Geological Survey \\ Menlo Park, California 90225
}

The U.S. Geological Survey has operated a strong-motion instrumentation network in Utah, located principally on and near the Wasatch Front. This program included not only the small group of accelerographs and seismoscopes referred to in your letter but an additional 23 accelerographs and one 12 channel recorder installed at selected structures and ground sites between Cedar City and Logan (see table below). The network is divided between instrumentation actually owned by the USGS and that which has been purchased by other Federal agencies but is maintained by the USGS. The latter category includes structural or structural related projects including those at the Salt Lake City VA Hospital and six Bureau of Reclamation dams or dam sites. To this date the only record from the network was obtained at the logan station as a result of the Northern Utah earthquake of 30 August 1962.

USGS OPERATED STRONG-MOTION NETWORK IN UTAH (As of August, 1985)

\begin{tabular}{|c|c|c|c|}
\hline UTAH & Station & Owner & Instrumentation \\
\hline & $\begin{array}{l}\text { Brigham City } \\
\text { City Water Works }\end{array}$ & USGS & SMA-3930 \\
\hline & $\begin{array}{l}\text { Cedar City } \\
\text { Southern Utah State College } \\
\text { Library Building Seismic Vault }\end{array}$ & USGS & SMA-1509 \\
\hline & $\begin{array}{l}\text { Deer Creek Dam } \\
\text { Toe } \\
\text { Left Abutment }\end{array}$ & Burec & $\begin{array}{l}\text { SMA-2293 } \\
\text { SMA-2294 }\end{array}$ \\
\hline & $\begin{array}{l}\text { East Canyon Dam } \\
\text { Right Abutment } \\
\text { Center Crest } \\
\text { Right Crest }\end{array}$ & Burec & $\begin{array}{l}\text { SMA-2302 } \\
\text { SMA-2203 } \\
\text { SMA-2304 }\end{array}$ \\
\hline & $\begin{array}{l}\text { Flaming Gorge Dam } \\
\text { Seismic Vault }\end{array}$ & Burec & SMA-2136 \\
\hline & $\begin{array}{l}\text { Hyrum Dàm } \\
12 \text { channel downhole } \\
\text { system in dam } \\
\text { Right Abutment }\end{array}$ & Burec & $\begin{array}{l}\text { CRA-171 } \\
\text { SMA-2301 }\end{array}$ \\
\hline & $\begin{array}{l}\text { Jordanelle Damsite } \\
\text { Ground }\end{array}$ & Burec & SMA-2295 \\
\hline
\end{tabular}


State University

Administration Building Basement

SMA-3929

Neph $i$

Jaub High School

USGS

SMA-1516

Ogden

Weber State College

USGS

SMA- 1489

Provo

Utah State Hospital

USGS

SMA-1506

Richfield

Utah Dept. of Highway Garage

SMA -4226

Salt Lake City

Cottonwood Elem. School Storage Building

USGS

SMA-3347

Eastwood Elem. School

USGS

SMA-3575

Liberty Bank

USGS

SMA -5310

NOAA ODserv., East Airport

USGS

SMA-5312

Roosevelt School

USGS

SMA -5308

ST\&T Comm., SLC Junction

USGS

SMA-5311

Sunnyside Training Center

USGS

SMA-5306

Temple Square West

USGS

SMA-5307

V.A. Hospital

VA

Building \#

Basement

9th Floor

SMA -170

SMA-547

Soldier Creek Dam

Left Abutment

Slope

SMA-3941

SMA-3939

crest

SMA-3940

Upper Stillwater Damsite Ground

SMA-2134 


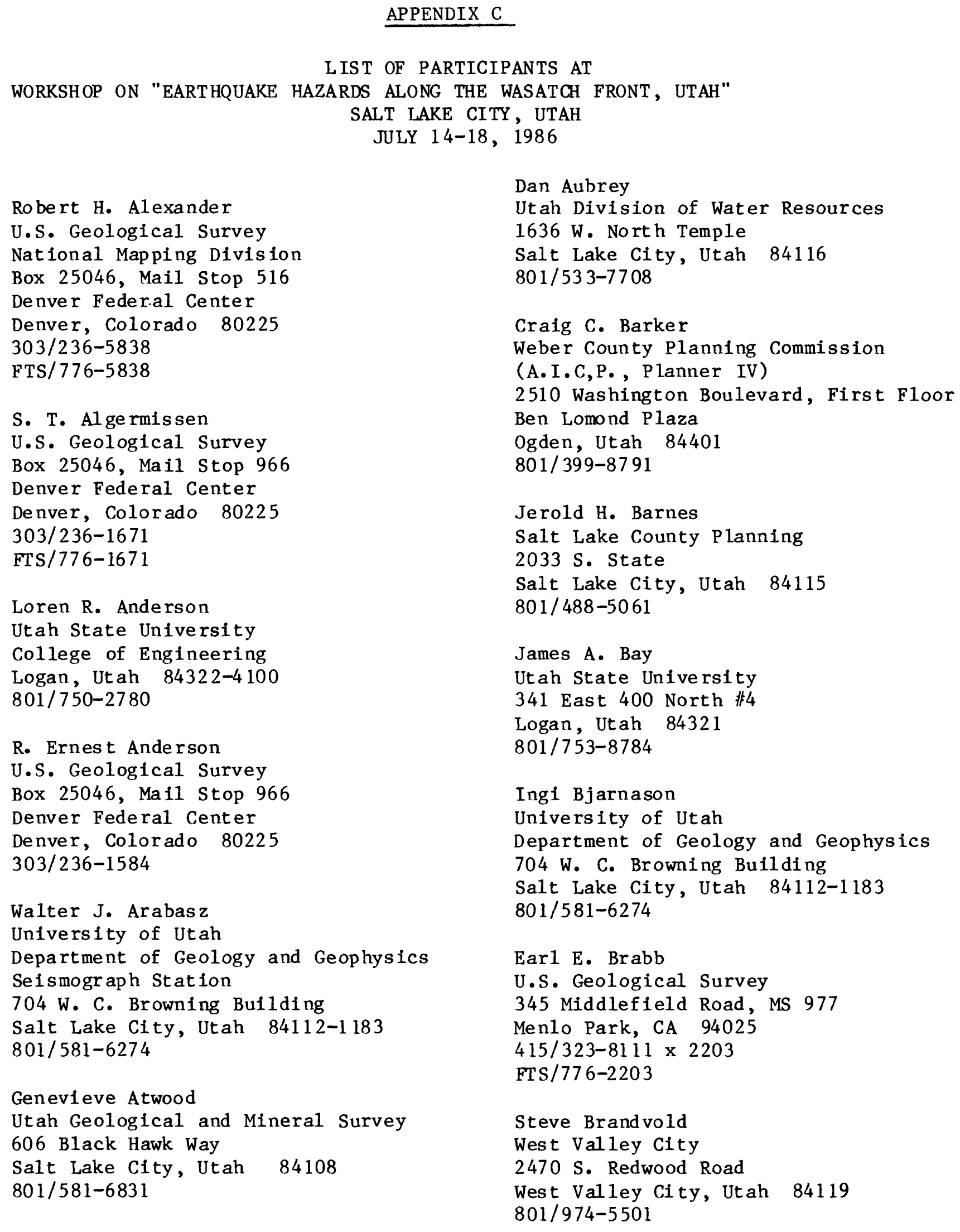


Mark Brenchley

City of Logan Planning Director

255 North Main Street

Logan, Utah 84321

$801-752-3060$

Lindie R. Brewer

U.S. Geological Survey

1433 North Lunnonhaus Drive 非5

Denver, Color ado 80401

$303 / 279-5232$

Ethan Brown

University of Utah Seismograph Station

704 M.C. Browning Building

University of Utah

Sa1t Lake City, Utah 84112

$801 / 581-6274$

William M. Brown III

U.S. Geological Survey

345 Middlefield Road, Mail Stop 998

Menlo Park, CA 94025

415/856-7112

Ronald Bruhn

Department of Geology \& Geophysics

University of Utah

Salt Lake City, Utah 84112

$801 / 581-7162$

Robert Buchanan

Salt Lake City Corp.

Room 414, City/County Building

Salt Lake City, Utah 84111

$801 / 535-7757$

David D. Burton

URS Corporation

46 West 300 South

Salt Lake City, Utah 84101

801/533-9133

Eugene E. Carr

A/P As sociates

740 E. 3900 South

Salt Lake City, Utah 84107

801/261-1999

Bill Case

Utah Geological and Mineral Survey

1466 Edi son

Salt Lake City, Utah 84115

801/466-8956
Amar Chake r

University of Science and Technology

Houari Boumediene

BP 3A El Alia Babezzouar

Alger, Alge ri a

Telephone 751287

Gary E. Christenson

Utah Geological and Mineral Survey

606 Black Hawk Way

Salt Lake City, Utah 84124

$801 / 581-6831$

Boyd Clayton

Ut ah Division of Water Resources

1636 W. No rth Temple

Salt Lake City, Utah 84116

$801 / 533-7708$

Charles M. Cornwal1

Center for Environmental Design Research

373 Worster Hall

University of Callfornia

Berkeley, Cali fornia 94720

415/642-2896

Brian Alexander Cowan

Federal Emergency Management Agency

500 C Street, S.W.

Washington, D.C. 20472

(202) 646-2821

Donald Currey

University of Utah

270 Orson Spencer Hall

University of Utah

Salt Lake City, Utah 84112

$801 / 581-7690$

Joyce E. Cutler

United Press International

143 So. Main Street 802

Salt Lake City, Utah 84110

$801 / 328-8866$

Wesley Dewsnup

Utah Division of Comprehensive Emergency

Man agement

1543 Sunnyside Avenue

Salt Lake City, Ut ah 84108

801/533-5271 
William K. Dinehart

Legislative Fiscal Analyst office

\#425 State Capito1

Salt Lake City, Utah 84114

801/533-5406

Bruce Eggleston

West Valley City

2470 S. Redwood Road

West Valley City, Utah 84119

801/974-5501

Ben Everitt

Utah Division of Water Resources

$1636 \mathrm{~W}$. North Temple

Salt Lake City, Utah 84116

801/533-7708

Cyrus Farahmandi

Utah Department of Transportation

4501 South 2700 West

Salt Lake City, Utah 84119

801/965-4189

Ralph Findlay

Utah Division of Comprehensive Emergency

Management

1543 Sunnyside Avenue

Salt Lake City, Utah 84108

801/533-5271

\section{Ducan Foley}

Earth Science Laboratory

391-A Chipeta

Salt Lake City, Utah 84108

$801 / 524-3431$

Harold E. Gill

Utah Geological and Mineral Survey

606 Black Hawk Way

Research Park

Salt Lake City, Utah 84108

$801 / 581-6831$

Phillip C. Goodrich

Emergency Management Team - City of Orem 56 North State Street

Orem, Utah 84057

801/224-7009
Paula L. Gori

U.S. Geological Survey

905 National Center

Reston, Virginia 22092

703/648-6707

FT S/959-6707

Chad Gourley

Utah Division of Water Rights

1636 West North Temple, Ro om 200

Salt Lake City, Utah 84116-3156

$801 / 533-6071$

Garry Guymon

Orem Department of Public Safety

56 North State Street

Orem, Utah 84057

$801 / 244-7087$

Val D. Hale

South Odgen City

560 - 39th Street

South Ogden, Utah 84403

801/399-4414

Richard Hall

Utah Division of Water Rights

1636 West North Temple

Room 200

Salt Lake City, Utah 84116-3156

$801 / 533-6071$

Perry James Hardin

University of Utah

$270 \mathrm{OSH}$, University of Utah

Department of Geography

Salt Lake City, Utah 84112

$801 / 581-8218$

Edwin L. Harp

U.S. Geological Survey

345 Middlefield Road, MS 998

Menlo Park, California 94025

415/856-7124

Kimm M. Harty

Utah Geological and Mineral Survey

606 Black Hawk Way

Salt Lake City, Utah 84108

$801 / 581-6831$ 
Wendy Hassibe

U.S. Geological Survey

8105 Federal Building

125 S. State

Salt Lake City Utah 84138

801-524-5652

FTS 588-5652

Walter W. Hays

U.S. Geological Survey

905 National Center

Reston, Virginia 22092

703-648-6711

FTS $959-6711$

Suzanne Hecker

Utah Geological and Mineral Survey

606 Black Hawk Way

Salt Lake City, Utah 84108

801/581-6831

Lynn Highland

U.S. Geological Survey

Box 25046, Mail Stop 966

Denver Federal Center

Denver, Colorado 80225

303/236-1671

FTS/776-1671

Julie Hill

University of Utah

336 I street 非

Salt Lake City, Utah 84112

801/581-6553

Lehi Hintze

Utah Geological and Mineral Survey

606 Black Hawk Way

Salt Lake City, Utah 84115

801/581-6831

Jerry M. Howel1

Provo City Planning office

P.0. Box 1849

Provo, Utah 84603

$801 / 375-1822 \times 400$

Raylene G. Ireland

Provo City

359 W. Center

Provo, Jtah 84601

801/375-1822 ext. 408
Lawrence P. James

Consulting Geologist

2869 Live Oake Circle

Salt Lake City, Utah 84117

801/277-4908

John Janson

West Valley City

2470 S. Redwood Road

West Valley City, Utah 84119

$801 / 974-5500$

Janine L. Jarva

Utah Geological and Mineral Survey

606 Black Hawk Way

Salt Lake City, Utah 84108

$801 / 581-6831$

Mark E. Jensen

Utah Geological and Mineral Survey

606 Black Hawk Way

Salt Lake City, Utah 84018

$801 / 581-6831$

E1don Jes sen

U.S. Geological Survey

National Mapping Division

Box 25046, Mail Stop 516

Denver Federal Center

Denver, Color ado 80225

303/236-5838

FTS/776-5838

Gary Johnson

Earthquake and Natural Hazards Division

Federal Emergency Management Agency

600 C Street, S.W.

Washington, D.C. 20472

202/646-2799

Bruce M. Kaliser

Utah Geological and Mineral Survey

606 Black Hawk Way

Salt Lake City, Utah 84108

$801 / 581-6831$

Jeffrey R. Keaton

Dames \& Moore

250 E. Broadway, Suite 200

Salt Lake City, Utah 84111

801/521-9255 
Donovan Kel1y

U.S. Geological Survey

119 National Center

Reston, Virginia 22092

$703 / 648-4460$

Kenneth W. King

U.S. Geological Survey

Box 25046, Mail Stop 966

Denver Federal Center

Denver, Color ado 80225

303/236-1591

FTS/776-1591

Mr. Robert H. Klauk

Ut ah Geological and Mineral Survey

606 Black Hawk Way

Sa1t Lake City, Utah 84108

$801 / 581-6831$

William J. Kockelman

U.S. Geological Survey

345 Middlefield Road, Mail Stop 922

Menlo Park, California 94025

415/323-8111 x 2312

FTS/467-2312

Robert Larson

U.S. Army Engineer

USAE-WE S-GL-GR

P.0. Box 631

Vicksburg, Mississippi 39180-0631

601/634-3201

Mike Lowe

Weber/Davis Counties Geologist

Weber County Planning Department

2510 Washington Boulevard

Ogden, Utah 84401

801/399-8791

William R. Lund

Utah Geological and Mineral Survey

606 Black Hawk Way

Salt Lake City, Utah 84108

$801 / 581-6831$

Don R. Mabey

Utah Geological and Mineral Survey

606 B1ack Hawk Way

Salt Lake City, Utah 84108

$801 / 581-6831$
Michael Machette

U.S. Geological Survey

Box 25046, Mail Stop 913

Denver Federal Center

Denver, Colorado 80225

30 3/236-1243

FTS/ 776-1243

Gary Madsen

Utah State Unviersity

Logan, Utah 84322

801/750-1233

Lincoln E. Malik

URS/Corporation

150412 Street

San Francisco, California 94103

415/957-5300

Peter May

University of Washington

Political Science DO-30

Seattle, Washington 98195

206/54 3-9842

Fred May

Utah Division of Comprehensive Emergency

Man agement

1543 Sunnyside Avenue

Salt Lake City, Utah 84108

801/533-5271

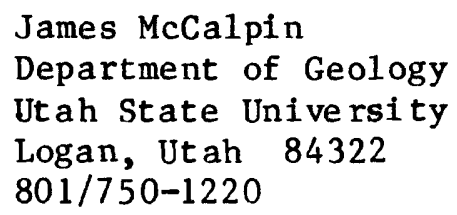

James McCalpin

Department of Geology

Utah State University

Logan, Utah 84322

$801 / 750-1220$

Jan M. McCu11oh

Federal Emergency Management, Region VIII

Denver Federal Center, Building 710

Box 25267

Denver, Colorado 80225-0267

303-235-4845

FTS3 22-4845

Peter McDonough

Mountain Fuel Supply Company

180 East First South Street

Salt Lake City, Utah 84139

801/534-5637 
Claire McHugh

Salt Lake Borad of Realtors

1625 So. Foothil1 Boulevard

Salt Lake City, Utah 84108

$801 / 582-9810$

Cla rk D. Meek

Bureau of Disaster Services

650 West State Street

Boise, Idaho 83720

208/334-3460

Sara Monteith

Utah State University

Box 3510

Logan, Utah 84321

$801 / 752-6605$

Joseph L. Moore

West Valley City

2470 S. Renwood Road

West Valley, Utah 84120

Linda s. Moore

State Department of Health, Public Water

Supp1ies

2531 Murray Ho1laday Road

Salt Lake City, Utah 84117

$801 / 538-6831$

Naser Mostaghe 1

University of Utah

Department of Geology and Geophysics

Seismograph Station

704 W. C. Browning Building

Sa1t Lake City, Utah 84112-1183

$801 / 581-7162$

Wi1liam Mulvey

Utah Geological and Mineral Survey

606 Black Hawk Way

Salt Lake City, Utah 84108

$801 / 581-6831$

Craig Nelson

Salt Lake City County Geologist

2033 South State Street

Building 1, Room 204

Salt Lake City, Utah 84115

$801 / 488-5061$
Deedee 0'Brien

Utah Museum of Natural History

Unive rsity of Utah

Salt Lake City, Utah 84112

$801 / 581-6927$

Jerome H. Oak1ey

Federa1 Emergency Management Agency

Region VIII, Denver Federal Center

Building 710

Denver, Colorado 80225-0267

303-23 5-4811

Sherry Oaks

U.S. Geological Survey

Branch of Geologic Risk Assessment

Box 25046, Mail Stop 966

Denver Federal Center

Denver, Colorado 80225

303/236-161 1

Susan $01 i g$

University of Utah

617 South 800 East

Salt Lake City, Utah 84102

801/355-0691

Jer ome M. 01son

Chief, Natural and Technological

Hazards Division

Building 710

Denver, Colorado 80225

$303 / 234-6582$

Joseph 01son

University of Utah-Civil Engineering

3012 M.E. B.

Salt Lake City, Utah 84112

$801 / 581-6536$

Kenneth J. Osborn

U.S. Geological Survey

222 West, 2300 South

Salt Lake City, Utah 84119

801/524-5695

William T. Par ry

Geology and Geophysics Department

University of Utah

Salt Lake City, Utah 84112

801/581-62 17 
James C. Pechmann

University of Utah

Department of Geology and Geophysics

Salt Lake City, Utah 84112-1183

801/581-3858

Les Pennington

KBK Enterprises

3191 So. Valley Street, Suite 208

Salt Lake City, Utah 84108

801/484-3131

Maurice Power

Geomatrix Consultants

One Market P1aza

Spear Street Tower, Suite 717

San Francisco, California 94105

415/957-9557

Keith J. Quigley

University of Utah Seismograph Stations

Salt Lake City, Utah $\mathbf{8 4 1 1 2}$

$801 / 581-6274$

Vicki A. Rasely

Real Estate Geology, Inc.

2397 Cinnabar Lane

Salt Lake City, Utah 84121

801/943-2239

Loren H. Rausher

Utah Department of Transportation

4501 South, 2700 West

Salt Lake City, Utah 84119

801/965-4326

Lawrence D. Reaveley

Reaveley Engineering \& As sociates

1515 So. 1100 East

Salt Lake City, Utah 84105

801/486-3883

Robert M. Robison

Ut ah/Juab County Geologist

c/o Utah County Planning Commission

188 East Center Street

Provo, Utah 84601

$801 / 373-5510 \times 500$
Albert Rogers

U.S. Geological Survey

Box 25046, Mail Stop 966

Denver Federal Center

Denver, Colorado 80225

303/236-1671

FTS/ 776-1671

Christopher Schaefer

Davis County Planning

P.0. Box 618

Farmington, Utah 84025

$801 / 451-3278$

Cal Schneller

Salt Lake City County Planning

2033 South State Street

Salt Lake City, Utah 84115

$801 / 488-5061$

Gerard Schuster

University of Utah

Geophysics Department

Salt Lake City, Utah 84112

David P. Schwarts

U.S. Geological Survey

345 Middlefield Road, MS 977

Menlo Park, California 94596

415/323-8111 × 2689

Graham F. Shirra

Weber County Planning Commission

(Director)

2510 Washington Boulevard, First Floor

Ben Lomond Plaza

Ogden, Utah 84401

801/399-8791

James E. Slosson

Slos son and As sociates

14046 Oxnard Street

Van Nuys, California 91401

8818/787-4555

Robert B. Smith

University of Utah

Department of Geology and Geophysics

702 Browning Building

Salt Lake City, Utah 84112-1183

801/581-7162 
Anna Grace Bellis Sperry

Government al Af fairs Chairperson

Salt Lake Board of Realtors

c/o Hooper-Ballstaedt

470 E. 3900 South

Salt Lake City, Utah 84107

801/226-2467

Douglas A. Sprinke1

Utah Geological and Mineral Survey

606 Black Hawk Way

Salt Lake City, Utah 84108

$801 / 581-6831$

Michael W. Stever

Weber County Emergency Management

2551 Grant Ave nue

Odgen, Jutah 84401

801/399-8473

Craig E. Taylor

NTS Engineering

6695 E. Pacific Coast Highway

Long Beach, California 90803

$213 / 493-6651$

Lorayne Tempest

Utah Division of Comprehensive Emergency

Management

1543 Sunnyside Avenue

Salt Lake City, Ut ah 84108

$801 / 533-5271$

Jim Tingey

Utah Division of Comprehensive Emergency

Management

1543 Sunnyside Ave nue

Salt Lake City, Utah 84108

$801 / 533-5271$

John C. Tinsley

U.S. Geological Survey

Branch of Regional Geology

345 Middlefield Road, Mail Stop 975

Menlo Park, California 94025

415/323-8111 x 2037

Paul The nhaus

U.S. Geological Survey

Box 25046, Mail Stop 913

Denver Federal Center

Denver, Colroado 80.225

303/236-1610

FTS/776-1610
Dale E. Topham

Utah State Unive rsity

246 Riverbend Road 非 1

Logan, Ut ah 84321

$801 / 752-3808$

Ursula K. Trueman

Bureau of Public Water Supplies

288 North 1460 West

P.0. Box 16700

Salt Lake City, Utah 84116-0700

$801 / 538-6839$

Lynne Turner

Taylorville-Bennion Comm. Council

Public Communication Director

1817 Condie Drive

Salt Lake City, Utah 84119

801/969-2278

Bruce Vandre

USFS

32425 th Street

Ogden, Ut ah 84401

$801 / 625-5237$

Del be rt Ward

Structural Facilities, Inc.

648 South 900 East

Salt Lake City, Utah 84102

$801 / 359-3364$

Rob Westaway

University of Utah

Department of Geology and Geophysics

Seismograph Station

704 W. C. Browning Building

Salt Lake City, Utah 84112-1 183

$801 / 581-6274$

Russell L. Whe eler

U.S. Geological Survey

Box 25046, Mail Stop 966

Denver Federal Center

Denver, Colorado 80225

303/236-1592

FTS/77 6-1592 


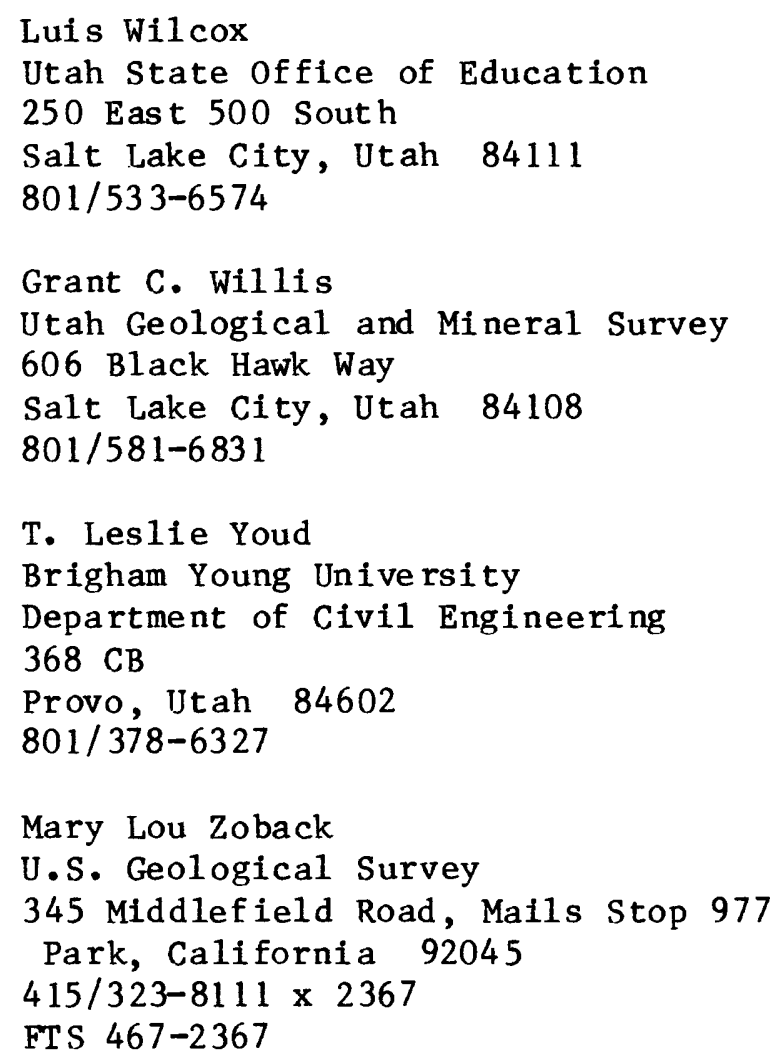

